\title{
Potential Growth of Nuclear and Coal Electricity Generation in the U.S.
}

August 1989

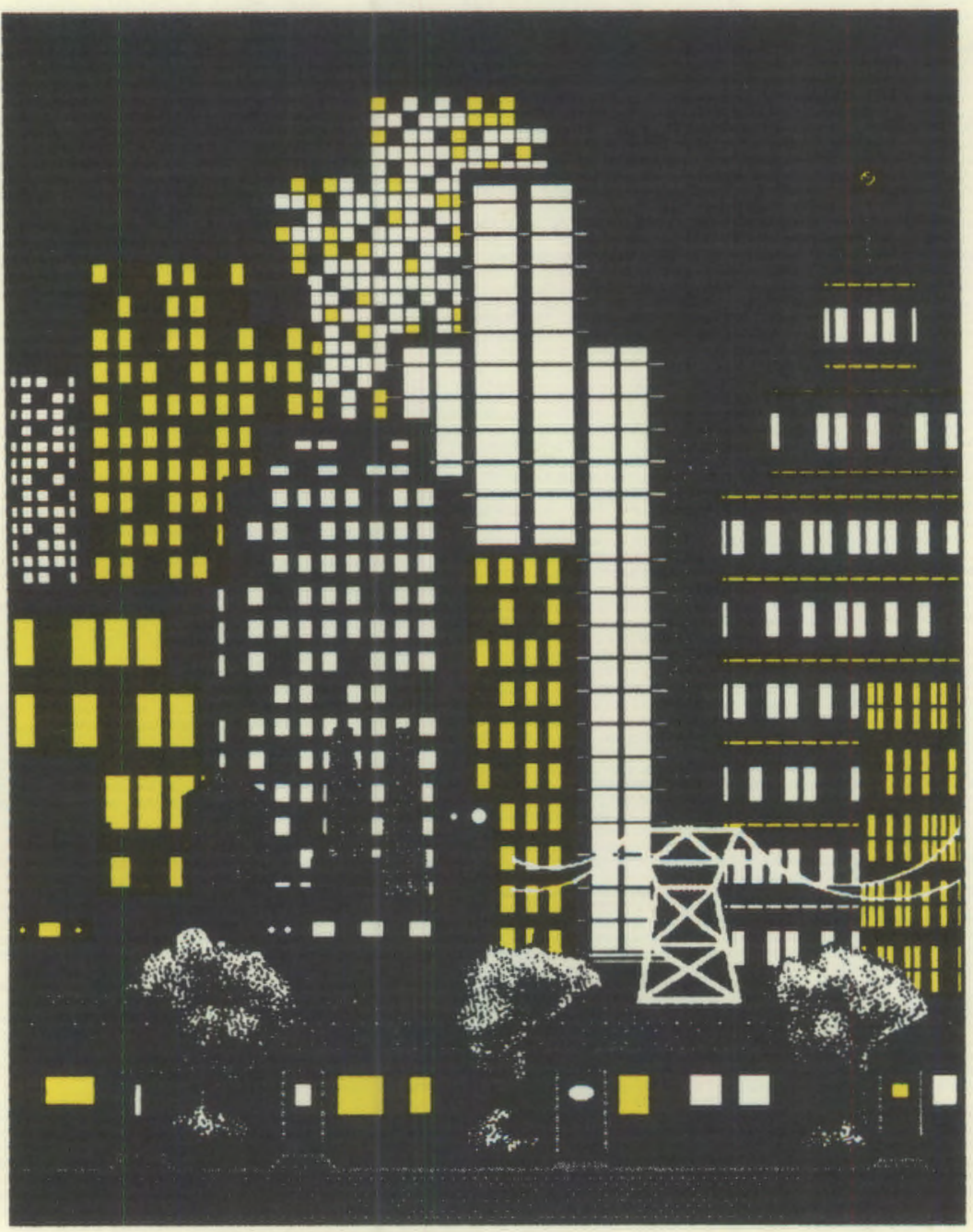

Prepared for the U.S. Department of Energy under Contract DE-AC06-76RLO 1830

Pacific Northwest Laboratory Operated for the U.S. Department of Energy by Battelle Memorial Institute 


\section{DISCLAIMER}

This program was prepared as an account of work sponsored by an agency of the United States Government. Neither the United States Government nor any agency thereof, nor Battelle Memorial Institute, nor any or their employees, makes any warranty, expressed or implied, or assumes any legal liability or responsibility for the accuracy, completeness, or usefulness of any information, apparatus, product, or process disclosed, or represents that its use would not infringe privately owned rights. Reference herein to any specific commercial product, process, or service by trade name, trademark, manufacturer, or otherwise, does not necessarily constitute or imply its endorsement, recommendation, or favoring by the United States Government of any agency thereof, or Battelle Memorial Institute. The views and opinions of authors expressed herein do not necessarily state or reflect those of the United States Government or any agency thereof.

\section{PACIFIC NORTHWEST LABORATORY operated by \\ BATTELLE MEMORIAL INSTITUTE for the \\ UNITED STATES DEPARTMENT OF ENERGY unc'er Contract DE-AC06-76RLO 1830}

Printed in the United States of America

Available to DOE and DOE contractors from the

Office of Scientific and Technical Information, P.O. Box 62, Oak Ridge, TN 37831; prices available from (615) 576-8401. FTS 626-8401.

Available to the public from the National Technical Information Service, U.S. Department of Commerce, 5285 Port Royal Rd., Springfield, VA 22161.

NTIS Price Codes, Microfiche A01

Printed Copy

\begin{tabular}{|c|c|}
\hline Pages & $\begin{array}{c}\text { Price } \\
\text { Codes }\end{array}$ \\
\hline$\overline{001-025}$ & $\mathrm{~A} 02$ \\
\hline $026-050$ & $\mathrm{~A} 03$ \\
\hline $051-075$ & $\mathrm{~A} 04$ \\
\hline $076-100$ & A05 \\
\hline $101-125$ & A06 \\
\hline $126-150$ & $\mathrm{~A} 07$ \\
\hline $151-175$ & A08 \\
\hline $176-200$ & $A 09$ \\
\hline $201-225$ & A10 \\
\hline $226-250$ & A11 \\
\hline $251-275$ & A12 \\
\hline $276-300$ & A13 \\
\hline
\end{tabular}


POTENTIAL GROWTH OF NUCLEAR

AND COAL ELECTRICITY

GENERATION IN THE U.S.

C. H. Bloomster

E. T. Merrill

August 1989

Prepared for

the U.S. Department of Energy

under Contract DE-ACO6-76RLO 1830

Pacific Northwest Laboratory

Richland, Washington 99352 


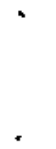




\section{ABSTRACT}

Electricity demand should continue to grow at about the same rate as GNP, creating a need for large amounts of new generating capacity over the next fifty years. Only coal and nuclear at this time have the abundant domestic resources and assured technology to meet this need. However, large increase in both coal and nuclear usage will require solutions to many of the problems that now deter their increased usage. For coal, the problems center around the safety and environmental impacts of increased coal mining and coal combustion. For nuclear, the problems center around reactor safety, radioactive waste disposal, financial risk, and nuclear materials safeguards.

This report assesses the impacts associated with a range of projected growth rates in electricity demand over the next 50 years. The resource requirements and waste generation resulting from pursuing the coal and nuclear fuel options to meet the projected growth rates are estimated. The fuel requirements and waste generation for coal plants are orders of magnitude greater than for nuclear. Improvements in technology and waste management practices must be pursued to mitigate environmental and safety concerns about electricity generation from both options. 
.

. 


\section{EXECUTIVE SUMMARY}

The growing demand for electricity in the United States will create a huge need for new generating capacity (Figure S.1). The long-term growth rate in electricity demand nationwide is projected by many sources to be between $1.5 \%$ and $3.5 \%$ per year. A growth rate near $2.5 \%$ appears to be the consensus. This study explores the long term implications of these growth rates. For instance, the $2.5 \%$ growth rate generates a cumulative need for nearly $2000 \mathrm{GW}$ of new capacity (about three times existing capacity) over the next 50 years. Of this, about $1200 \mathrm{GW}$ is needed to meet baseload.

For perspective, $1200 \mathrm{GW}$ is equivalent to about 1000 large nuclear power plants or 2000 large coal-fired powerplants. That averages to 20-40 new large power plants per year. Only the coal and nuclear options have the abundant domestic resources and assured technology at this time to meet this large a need for baseload capacity. $0 \mathrm{il}$ and natural gas probably have sufficient resources, but oil imports are already large and gas is

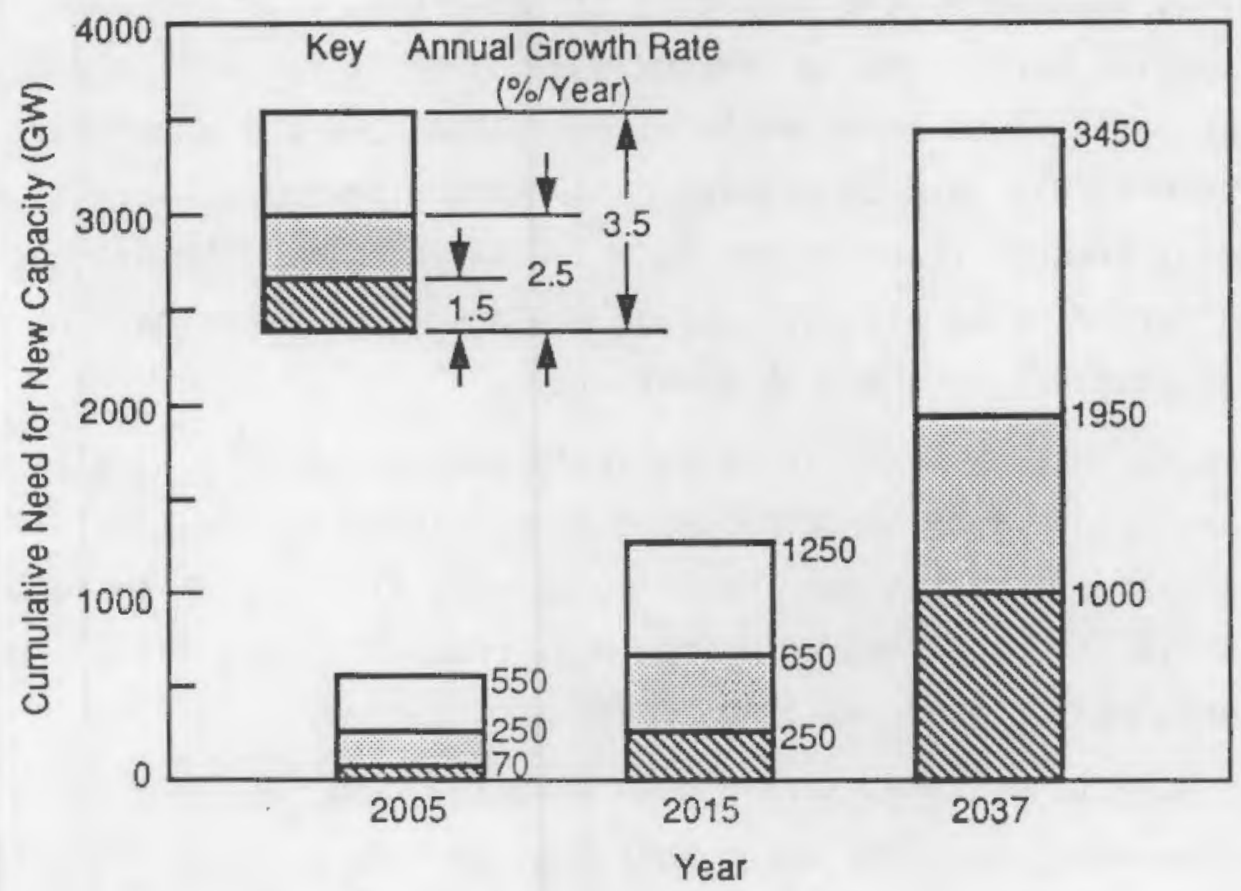

FIGURE S.1. Growth in Electricity Demand will Create a Huge Need for New Generating Capacity 
expected to be more costly and more valuable for uses other than baseload generation. Other electricity generation technologies either do not have sufficient resources or require technological breakthroughs to become competitive on a large scale.

The need for new baseload capacity at the $2.5 \%$ growth rate could be entirely met by either coal or nuclear. However, if all of this new baseload capacity is supplied by coal, today's environmental concerns about acid rain, the greenhouse effect, and other impacts from coal combustion would be increased about five-fold. Thus, the need for clean coal technologies is obvious and questions concerning the greenhouse effect need to be resolved soon. On the other hand, if all of the new baseload capacity is supplied by nuclear, then ten times as much new nuclear capacity must be built as exists today.

If the higher $(3.5 \%)$ growth rate were to occur, the fuel and waste disposal requirements would be about twice that for the $2.5 \%$ growth rate. The all-coal and all-nuclear option for this growth rate might encounter supply problems because of the depletion of resources. For instance, the all-nuclear option would consume uranium equivalent to our entire domestic resources estimated to be recoverable at less than $\$ 500$ per pound $\mathrm{U}_{3} 0_{8}$. This would undoubtedly lead to uranium conservation measures, such as the introduction of breeder reactors and $\mathrm{Pu}$ and $U$ recycle, well before the end of the study period. The all-coal option would consume about half of the domestic coal reserves at the $3.5 \%$ growth rate.

Given these consequences, it is unlikely that baseload demand at a $2.5 \%$ or higher growth rate would be supplied by either all coal or all nuclear, but rather that the need would be jointly filled by both fuel types. In addition, other technologies, e.g. renewables and fusion, would be used to help meet demand, as they became competitive.

If the lower $(1.5 \%)$ growth rate were to occur, the fuel and waste disposal requirements would be about half that for the $2.5 \%$ growth rate. However, even at this low growth rate, large amounts of new capacity are 
required. An average of $18 \mathrm{GW} /$ year of new capacity must be added between 2005 and 2015. This would increase to about $40 \mathrm{GW} /$ year at the end of 50 years.

Besides growth, the need for new generating capacity is increased by the need to replace obsolete capacity. In 1988, there were $658 \mathrm{GW}$ of installed capacity; most of this will need to be replaced over the next 50 years. The need to replace obsolete capacity is only about $1 \mathrm{GW} /$ year today but should increase to over $20 \mathrm{GW} /$ year by 2010 .

As the demand for electricity continues to grow, the need for new power plants will become more evident than it is today. Coal and nuclear, which provide nearly three-fourths of current electricity generation, will be called on to meet most of the reed for new capacity. However, large increases in both coal and nuclear usage will not be acceptable to society without solutions to many safety, environmental, and economic concerns. For coal, notable issues are acid rain, the greenhouse effect, acceptable emission limits, occupational health and safety, and mine reclamation. For nuclear, notable issues include reactor safety, radioactive waste disposal, financial risk, and liability limits. Resolution of these issues will require both technological improvements and institutional innovations. Given the long lead time for research and technology development, planning decisions must be undertaken now to assure that acceptable technology will be available to meet the future needs. Solving these problems should be approached with a sense of urgency. Today's surplus generating capacity will soon disappear.

World-wide use of nuclear power is increasing as other nations seek independence from imported fossil energy, increased cost competitiveness, and reduced environmental pollution. Many of the 31 nations that now have nuclear power plants in operation or under construction plan to increase their nuclear capacity. World nuclear capacity increased $4 \%$ in 1988 to $310 \mathrm{GW}$ produced by 428 reactors. Nuclear energy now provides $20 \%$ of the world's electricity generation and over $50 \%$ of the electricity supply in some nations. 
Most nations plan to build light water reactors, particularly the large PWR. The trend is toward larger units of standardized design; for instance, in France new plants will be 1400 MW PWRs with plans for $2000 \mathrm{MW}$ later. Most foreign nations plan to reprocess spent fuel and recycle the $\mathrm{U}$ and $\mathrm{Pu}$ in light water reactors. Development of the breeder reactor is continuing in several nations, but widespread deployment appears to be at least 30 years away.

Increasing foreign nuclear usage should impact the domestic nuclear industry in several ways. First, increased resource depletion could lead to increased fuel costs and greater incentives for uranium and plutonium recycle and breeding. Second, greater activity and international competition should spur technological advances. Third, increased operating experience should lead to improved designs and operating procedures. Fourth, more widespread usage should lessen opposition and lead to acceptable solutions to current political and institutional issues. Fifth, an active global market should sustain modern, competitive production capabilities and supporting infrastructure.

The fuel consumption in a coal-fired power plant is roughly 100,000 times greater by weight than in a nuclear plant to generate the same amount of electricity. Nearly all of the coal converts into gaseous products of combustion, predominately $\mathrm{CO}_{2}$. Although $\mathrm{CO}_{2}$ emissions are not presently regulated, atmospheric warming (the greenhouse effect) is a potential concern in the long-term. About 3 tons of $\mathrm{CO}_{2}$ are produced for every ton of coal burned. Coal combustion also produces $\mathrm{SO}_{2}$ and $\mathrm{NO}_{\mathrm{x}} \cdot \mathrm{SO}_{2}$ and $\mathrm{NO}_{\mathrm{x}}$ emissions which contribute to acid rain are regulated now, and more stringent regulations may be imposed. In contrast, nuclear fission produces no $\mathrm{CO}_{2}$ ' no $\mathrm{SO}_{2}$, no $\mathrm{NO}_{x}$, and a negligible quantity of gaseous emissions. 


\section{ACKNOWLEDGMENT}

The authors gratefully acknowledge the study guidance and constructive reviews provided by Edward MastaI, Department of Energy, and Laurin Dodd, John Burnham, William Richmond, and Richard Nightingale of the Pacific Northwest Laboratory. 


\section{CONTENTS}

ABSTRACT ..................................... i i

EXECUTIVE SUMMARY . . . . . . . . . . . . . . . . . . . v

ACKNOWLEDGMENT . . . . . . . . . . . . . . . . . . . ix

INTRODUCTION . . . . . . . . . . . . . . . . . . . 1

FORECASTS OF ELECTRICITY DEMANO . . . . . . . . . . . . . . 3

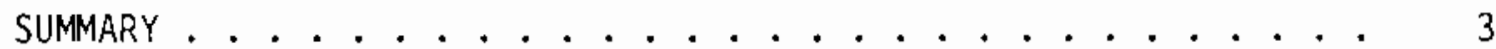

NATIONAL FORECASTS ............................. 3

FACTORS AFFECTING ELECTRICITY DEMAND...$\cdots$

NERC FORECASTS TO 1996 . . . . . . . . . . . . . . 7

REGIONAL FORECASTS ...................... 9

PROJECTIONS OF THE NEEd FOR NEW GENERATING CAPACITY . . . . . . . . . 11

SUMMARY . . . . . . . . . . . . . . . . . . 11

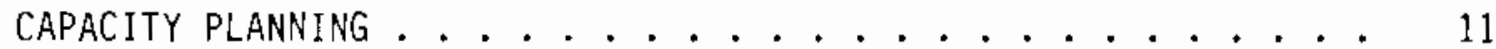

Peak Demand . . . . . . . . . . . . . . . . 11

Reserve Margin . . . . . . . . . . . . 12

Retirement of Obsolete Capacity .. . . . . . . . . 14

SCENARIOS FOR ESTIMATING LONG-TERM CAPACITY NEEDS . . . . . . . 16

PEAK DEMAND PROJECTIONS TO 2037 . . . . . . . . . . . . . . . 16

TOTAL CAPACITY REQUIREMENTS . . . . . . . . . . . . . . 17

ANNUAL REQUIREMENTS FOR NEW CAPACITY . . . . . . . . . . . . 21

Planning Uncertainties................ . . 24

IMPORTANCE OF LONG-TERM AND NEAR-TERM PROJECTIONS . . . . . . . 25

SUPPLY OPTIONS . . . . . . . . . . . . . . . . . . . . 27

GENERATION PATTERNS . . . . . . . . . . . . . . . . 27 


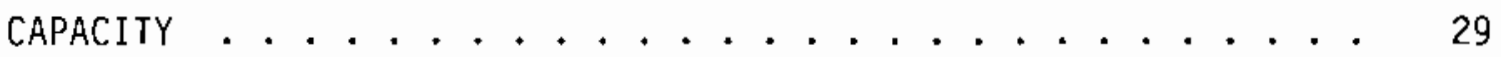

FUTURE SUPPLY OPTIONS ........................ 29

RESOURCE CONSUMPTION AND WASTE PRODUCT GENERATION . . . . . . 33

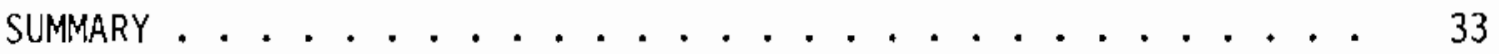

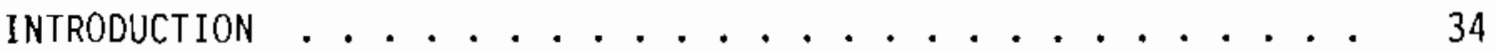

Nuclear and Coal Supply Scenarios ......... 35

Comparison with EIA Projections. . . . . . . . 36

CRITICAL RESOURCE REQUIREMENTS .................. 36

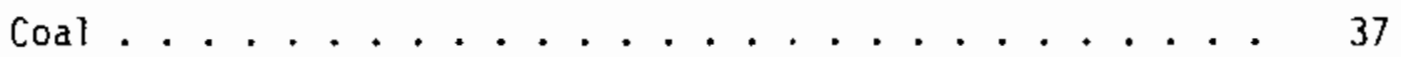

$\mathrm{U}_{30} 0_{8} \ldots \ldots \ldots \ldots \ldots$

Uranium Enrichment . . . . . . . . . . 39

Spent Fuel oisposal ............. 40

Reprocessing ................. 4 41

Potential Growth in Annual Fuel and Waste Disposal

Requirements............... 41

FOREIGN NUCLEAR TRENDS ........................ 45

DISCUSSION AND CONCLUSIONS .................... 49

REFERENCES .......................... 55

GLOSSARY ............................ 59

APPENDIX A - PROJECTIONS OF ELECTRICITY DEMAND . . . . . . . A.1

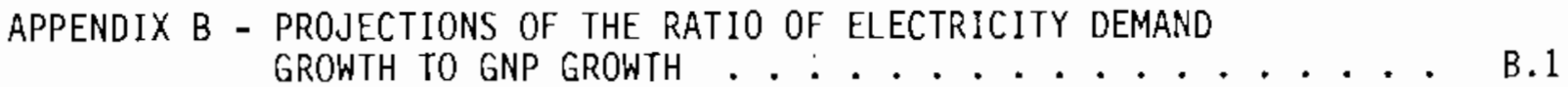

APPENDIX C - NERC REgIONS ............... C.1

APPENDIX 0 - LOAD DURATION CURVES ............ D. 1

APPENDIX E - CAPACITY PROJECTIONS . . . . . . . . . E.1

APPENDIX F - TABULATION OF RESOURCE CONSUMPTION AND WASTE 
APPENDIX G - FUEL CYCLE ASSUMPTIONS . . . . . . . . . . . G.1

APPENDIX H - NUCLEAR CONTRIBUTION BY NERC REGION IN 1986 . . . . . H. 


\section{$\underline{\text { FIGURES }}$}

1 Forecasts of Electricity Demand . . . . . . . . . . . . . 4

2 Historic Growth in Electricity Consumption and Real GNP. . . . . 5

3 Growth Rates of United States Electricity Use and GNP . . . . . 6

4 Historic Residential Electricity Prices in Constant 1987 Dollars . . . . . . . . . . . . . . . . 7

5 Historic Growth of Electricity Demand and Generating Capacity .................... 12

6 Variations in Annual National Peak Load and Energy Demand . . . . 13

7 Effect of Availability on Margins . . . . . . . . . . 15

8 Projected Peak Demand for Three Growth Rates . . . . . . . . . 17

9 Capacity Requirenents for Three Growth Scenarios . . . . . . 18

10 Incremental Capacity Requirement for Three Growth Scenarios . . . 19

11 Cumulative Retirements of obsolete Capacity for Selected
Service Life Assumptions . . . . . . . . . . . . . 20

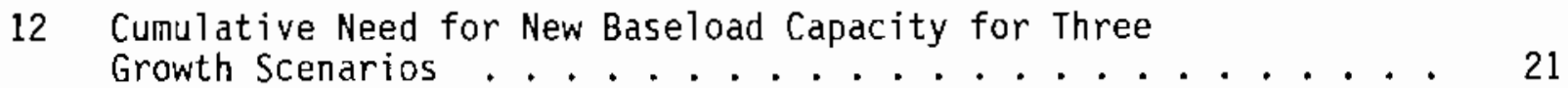

13 Annual Additions to U.S. Generating Capacity . . . . . . . . 22

Annual New Capacity Requirements in Selected Years
for Three Scenarios . . . . . . . . . . . . . 23

15 Annual Need for New Baseload Capacity in Selected Years

16 Electricity Generation by Fuel Type . . . . . . . . . . 27

17 Electricity Production by Fuel Type . . . . . . . . . . . . 28

18 Generating Capacity by Fuel Type . . . . . . . . . . . . 29 


\section{$\underline{\text { TABLES }}$}

1 NERC 1988 Forecasts for Selected Years . . . . . . . . 8

2 Projected Regional Growth Rates in Electricity Demand and

Peak Load . . . . . . . . . . . . . . . . . 10

3 Scenarios for Determining Capacity Requirements . . . . . . 16

4 Cumulative Incremental Need for New Capacity for Both

Load Growth and Replacement of Obsolete Capacity for

Selected Years ......................

5 Coal Consumption Assuming all Future Additions to Base Load

Capacity are Coal-Fired . . . . . . . . . . . . . . .

6 Consumption of $\mathrm{U}_{3} \mathrm{O}_{8}$ Assuming Nuclear Energy is used to

Meet all Future Additions to Base Load Capacity . . . . . . . . .

7 Cumulative Capacity in New Baseload Plants Required over

Fifty Years for Alternative Growth Scenarios . . . . . . . . 35

8 Alternative Coal and Nuclear Supply Scenarios and Options . . . 36

9 Consumption of U.S. Recoverable Coal Reserves Over the

Next 50 Years . . . . . . . . . . . . . . . 37

10 Consumption of $\mathrm{U}_{3} \mathrm{O}_{8}$ Over the Next 50 Years . . . . . . . 38

11 Year in which Existing Enrichment Capacity is Reached under

Alternate Scenarios ...................

12 Estimated Fuel Requirements and Waste Generation for

Coal-Generated Electricity in 1987 and 2037 . . . . . . . .

13 Estimated Fuel Cycle Requirements and waste Generation

for Nuclear-Generated Electricity in 1987 and 2037 . . . . . . 43

14 Foreign Reprocessing Capacity . . . . . . . . . . . . 46 


\section{INTRODUCTION}

The purposes of this report are: 1) to assess the potential range of future electricity demand in the United States by evaluating forecasts of electricity demand, 2) to derive estimates of the long-term need for new generating capacity, and 3) to evaluate the implications of meeting this need through alternative nuclear and coal supply scenarios.

We examine the potential demand for electricity over the next 50 years. A 50-year period was selected for several reasons: first, because of the long time required to deploy new generating technology; second, to provide a sufficient time span in which to consider the impacts of retiring most of the current capacity; and third, because nearly all power plants completed in the future will still be in operation. At least 20 years are required before new generating technology can be developed, demonstrated and deployed on a large scale. Most of the new power plants that will be brought on-line with in the next ten years are now under construction. Decisions on large capacity additions for the following ten years must be made in the next ten years and must be based largely on proven or evolutionary technology. Therefore, the potential market for new generating technology is determined primarily by the need for new capacity after the next twenty years.

Assumptions about the future are necessary for today's business decisions and provide a basis for strategic planning. Long-term projections are important, but not in an absolute sense, since plans can be periodically revised. Long-range planning is required to efficiently and reliably meet projected demands at the lowest economic and social cost, particularly taking into consideration the long lead times required for technology development, siting, power plant construction, and licensing.

In this study our primary concern is with the aggregate need for new capacity in the U.S. over the long term. Historically, the national electricity demand is strongly related to the gross national product, which is used as a predictor in most forecasts. Although utilities plan and add capacity on a regional basis, there is much commonality between regions in the supply options and in the overall economic factors that determine demand. 
The differences between regions in the supply options are primarily related to the transportation costs of fuel and the availability of indigenous economically-recoverable energy resources. A potential drawback to focusing on the aggregate need is that regional shortages may be masked in the short term, but since our perspective is on meeting long-term needs, temporary regional imbalances are not significant to our objectives.

The primary focus in this study is the need for baseload generating capacity. Baseload plants produce about $80 \%$ of the energy generated. Baseload capacity operates over extended periods of time without interruption. The remaining energy is generated by load-following plants which operate intermittently, usually cycling on a daily basis and by peaking plants which operate for short periods of time, hours or minutes, during the peak Toads.

This report is organized in six sections. The first section, Forecasts of Electricity Demand, analyzes recent long-range forecasts and discusses the factors that affect electricity demand. The second section, Projections of the Need for New Generating Capacity, estimates the long-term needs for new capacity under three scenarios. The third section, Supply options, discusses the current electricity supply and summarizes future options. The fourth section, Resource Consumption and Waste Generation, compares coal and nuclear fuel cycles currently and under the three long-term scenarios. A fifth section, Foreign Nuclear Trends summarizes nuclear trends abroad. In the sixth section, Discussion and Conclusions, the implications of the data and the various supply and demand scenarios are presented.

This report updates and expands upon a previous report on the longterm need for new generating capacity (BL 87). In the two years since the previous report, electricity demand, in response to the strong economy, has risen much more sharply than most forecasters had predicted. 


\section{FORECASTS OF ELECTRICITY DEMAND}

\section{SUMMARY}

Nearly all sources forecast electricity demand to grow at an annual rate between $1.5 \%$ and $3.5 \%$. Growth in electricity demand is closely tied to growth in the GNP. Forecasts of the ratio of growth in electricity demand to growth in the GNP range from 0.6 to 1.4 with an average of about unity. Long-range forecasts of GNP annual growth rates range from 2 to $3 \%$.

Current 10-year utility planning is based on an average annual growth in summer peak demand of $1.9 \%$ and an average annual growth in generating capacity of $1.2 \%$. This will reduce the reserve margin, on a nationwide basis, from a current value of $30 \%$ to $22 \%$ in 1997 . Utility forecasts predict summer peak demand of $594 \mathrm{GW}$ in 1997 and planned capacity of $728 \mathrm{GW}$. Most of this new capacity is currently under construction. Of the $85 \mathrm{GW}$ of planned net capacity additions from 1988 through 1997, 15 GW will be supplied by coal units, 22 GW will be supplied by nuclear units, and $20 \mathrm{GW}$ will be supplied by non-utility generators.

\section{NATIONAL FORECASTS}

Numerous forecasts of electricity demand are made each year (Appen$\operatorname{dix} A)$. Most of the forecasts fall within a range of growth rates varying from $1.5 \%$ to $3.5 \%$ per year (Figure 1 ). The most recent forecasts range from 2.0 to $3.2 \%$ growth rates. These forecasts provide estimates of the probable bounds for electricity demand to year 2015. For comparison, these growth rates are projected to the year 2037 to illustrate the long term effect of a continuation of these growth rates.

Most of the forecasts are derived from imputed relationships between electricity demand and economic activity, primarily gross national product (GNP). Recent forecasts of the ratio of electricity demand growth to GNP growth (Appendix B, Table B.1) range from 0.58 to 1.35 with the mean and median being slightly less than 1.00. Recent forecasts of annual GNP growth rates to year 2000 range from 2.3 to $2.9 \%$ with the mean at $2.6 \%$ (Appendix $B$, Table B.2). 


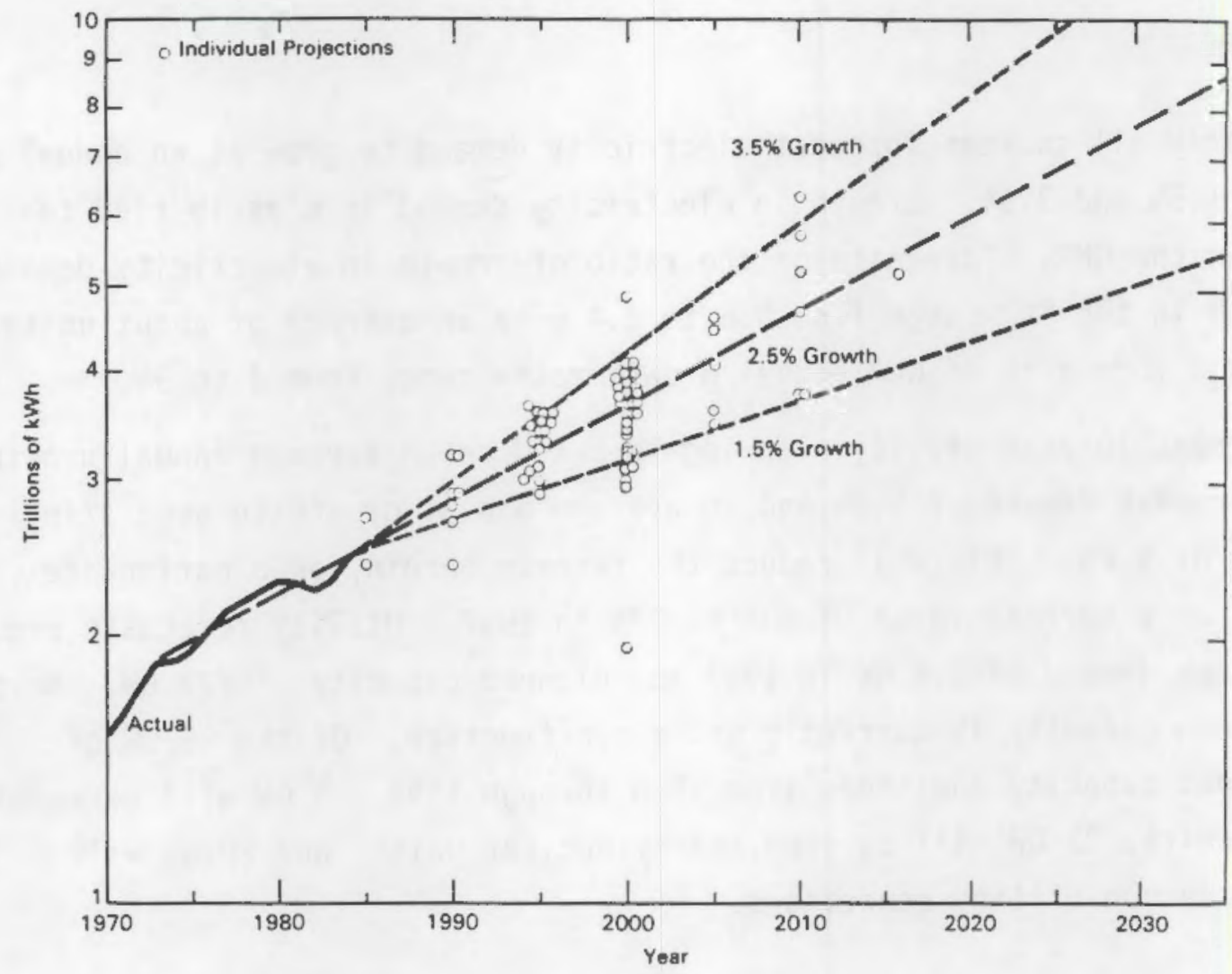

FIGURE 1. Forecasts of Electricity Demand

\section{FACTORS AFFECTING ELECTRICITY DEMAND}

Econometric studies link electricity demand to economic activity. Electricity demand and real GNP have grown consistently over time (Figure 2). The growth rate in electricity demand exceeds GNP growth rate by about a factor of two through 1973. Since 1973, electricity growth generally matches GNP growth (Figure 3 ) and electricity consumption has remained nearly constant at 0.55 kwh per dollar (1987) of real GNP.

One reason for the decline in growth rate since 1973 was the increase in real (constant dollar) electricity prices (Figure 4). Prior to 1972 real electricity prices steadily declined (DOE 85a, pp. 60-61). Steep 


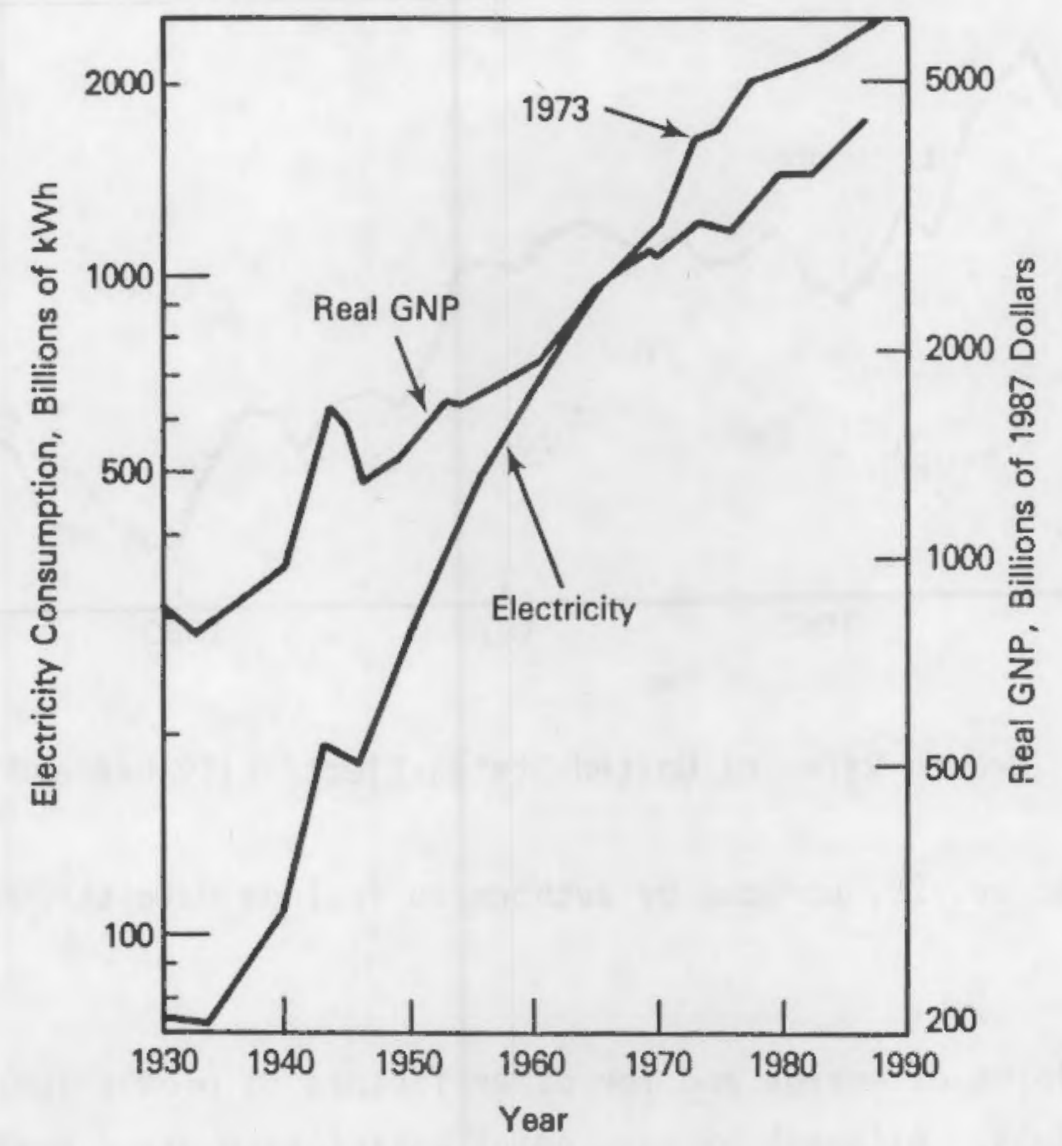

FIGURE 2. Historic Growth in Electricity Consumption and Real GNP

increases in real electricity prices followed the large increases in petroleum prices in 1973 and 1979. Real electricity prices, however, have remained nearly constant since 1982 and are projected to remain nearly constant through 2000 (EW 88, p. 69).

We think real electricity prices will decline over the long term, but much more slowly than they did in the past, in response to technology improvements and because the industry is less vulnerable to imported oil and many of the other factors that led to the severe energy price increases. Declining real prices should lead to a general increase in consumption.

Revenues from electricity sales are currently about 4\% of GNP. However, $4 \%$ in no sense represents an upper limit since electricity is substitutable 


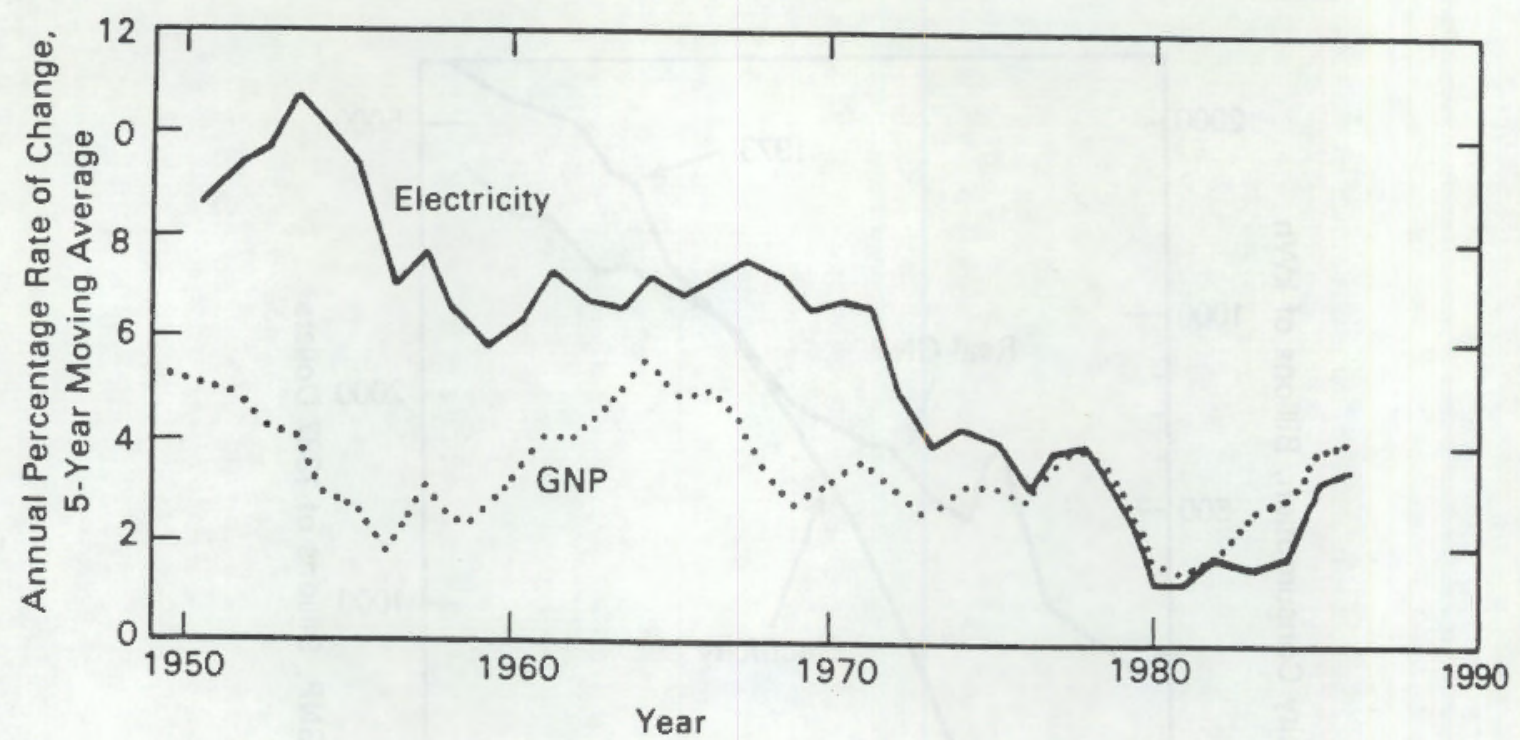

FIGURE 3. Growth Rates of United States Electricity Use and GNP

Source: NRC 86, p. 25, updated by authors to include data through 1988.

both for other forms of energy and for other factors of production; e.g., labor and materials. Although at some point market saturation must occur, that point may be substantially above the current level. Currently, total energy sales alone, for example, comprise about $10 \%$ of GNP.

Therefore, over the long-term, we expect electricity demand to track the economy. The economy, as measured by real GNP, has typically grown at the rate of 2 to $4 \%$ per year with the long-term average near 3\%. Real GNP should continue to grow in response to increased population and productivity. The average growth rate for GNP in recent forecasts is $2.6 \%$ per year to year 2000 (see Table B.2, Appendix B).

Although weather strongly affects electricity demand (DOE 85b, pp. 18-20), yearly weather variations are not predictable and tend to balance out over time. An allowance for abnormal weather must be included in the reserve margin, however. 


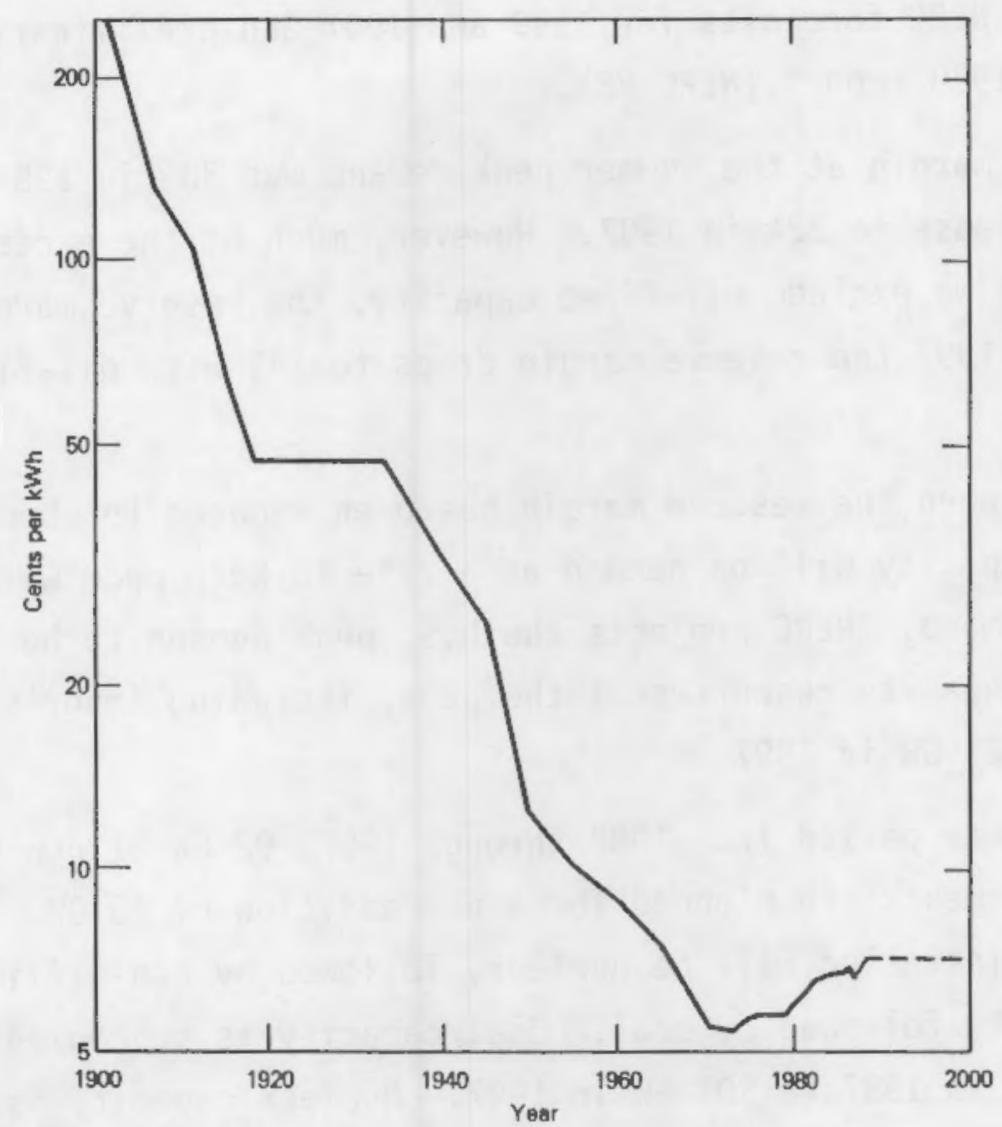

FIGURE 4. Historic Residential Electricity Prices in Constant 1987 Dollars

NERC FORECASTS TO 1996

The North American Electric Reliability Council (NERC) annually forecasts annual demand, peak demand, and capacity for the next 10 years. The forecast is an aggregation of individual utility system forecasts representing virtually all of the power systems in the United States and Canada.

The 1988 NERC forecast (NERC 88) is for average annual growth rates in the summer peak demand of $1.9 \%$, in net energy for load of $2.0 \%$, and in installed generating capacity of $1.3 \%$. The uncertainty ranges in the NERC forecasts to 1997 are estimated to be 1.0-2.6\% per year for peak load and $0.9-2.8 \%$ per year for net energy for load. The uncertainty ranges cover an $80 \%$ probability band; there is a $10 \%$ probability that the upper bound 
will be exceeded and a 10\% probability that the lower bound will be exceeded. Table 1 presents NERC forecasts for 1990 and 1997 and preliminary data for 1988 from their 1988 report (NERC 88).

The reserve margin at the summer peak demand was $30 \%$ in 1988, and is projected to decrease to $22 \%$ in 1997 . However, much of the excess capacity is oil-fired. If we exclude oil-fired capacity, the reserve margin is only $21 \%$ in 1988. By 1997 the reserve margin drops to $14 \%$ with oil-fired capacity excluded.

After 1997, when the reserve margin has been reduced to about $20 \%$, new generating capacity will be needed at a rate to keep pace with the growth in peak demand. NERC projects the U.S. peak demand to be 594 GW in 1997. The U.S. capacity resources at the peak, including imports, is projected to be $725 \mathrm{GW}$ in 1997.

In the ten-year period from 1988 through 1997, 92 GW of new capacity and $7 \mathrm{GW}$ in retirements are planned for a net addition of $85 \mathrm{GW}$. Most of the new capacity installed will be nuclear, followed by non-utility generating capacity followed by coal. Coal capacity is scheduled to increase 15 GW from 286 GW in 1987 to 301 GW in 1997. Nuclear capacity is scheduled to increase $22 \mathrm{GW}$, from 85 to $107 \mathrm{GW}$. Hydro capacity is scheduled to

\section{TABLE 1. NERC 1988 Forecasts for Selected Years}

\begin{tabular}{|c|c|c|c|c|}
\hline & $\begin{array}{l}1988 \\
\text { Preliminary } \\
\end{array}$ & $\begin{array}{l}\text { Forec } \\
1992 \\
\end{array}$ & $\frac{\text { sts }}{1997}$ & $\begin{array}{c}\text { Average Annual } \\
\text { Increase } \\
1988-1997, \% \\
\end{array}$ \\
\hline Peak demand, GW & 500 & 541 & 594 & 1.9 \\
\hline Net energy for load (TWh) & 2,690 & 2,916 & 3,210 & 2.0 \\
\hline Installed capacity, GW & 658 & 695 & 725 & 1.0 \\
\hline $\begin{array}{l}\text { Planned Capacity Resources, } \\
\text { Summer, GW }\end{array}$ & 650 & 696 & 728 & 1.2 \\
\hline Reserve Margin, $\%$ & 30 & $29^{*}$ & $22^{*}$ & $(2.7)$ \\
\hline
\end{tabular}

TWh = Tera watt hours = billions of $\mathrm{kWh}$.

* Based on planned resources. 
decrease $1 \mathrm{GW}$ to $70 \mathrm{GW}$. Natural gas capacity is scheduled to increase $9 \mathrm{GW}$ to $63 \mathrm{GW}$. 0 il capacity is scheduled to increase $3 \mathrm{GW}$ to $61 \mathrm{GW}$. Dual (oil/gas) fuel capacity is scheduled to increase $4 \mathrm{GW}$ to $72 \mathrm{GW}$. Pumped storage is scheduled to increase $2 \mathrm{GW}$ to $18 \mathrm{GW}$. Other utility generating capacity (geothermal, wind, solar, cogeneration, and biomass) is scheduled to increase from 3 to $6 \mathrm{GW}$. Non-utility generating capacity is scheduled to increase $20 \mathrm{GW}$ to $28 \mathrm{GW}$. The above capacities are rounded to the nearest GW and refer to the summer capability.

Planned retirements by utilities through 1997 are 156 units with a total capacity of $7 \mathrm{GW}$. These are primarily small petroleum and natural gas units (NERC 87). The average unit size of the capacity to be retired is $47 \mathrm{MW}$. The largest power plant to be retired is the $840 \mathrm{MW}$ Hanford nuclear plant. The planned capacity retirements are fueled by oil (2 GW) and natural gas (2 GW), coal (2 GW), and nuclear (1 GW).

The rate of retirements over the next 10 years corresponds to the installation rate of new capacity 50 to 60 years ago. Thus, the planned retirement schedule reflects overall aging and is consistent with plant life extension programs. The average age of installed capacity would reach about 23 years in 1995, up from 15 years in 1985.

\section{REGIONAL FORECASTS}

Different parts of the nation are expected to grow at different rates. Recent forecasts to 1997 (NERC 88) of peak loads and electricity demand by NERC region are shown in Table 2. Note: 1) the range of peak load growth rates varies from a low of $1.0 \%$ in the South Central Illinois subregion to a high of $2.9 \%$ in the Florida subregion, and 2) the range of net energy for load growth rates varies from a low of $1.1 \%$ in the NW Pool to a high of $3.4 \%$ in the Arizona-New Mexico subregion. 
IABLE 2. Projected Regional Growth Rates in Electricity Demand and Peak Load

\begin{tabular}{|c|c|c|c|c|c|c|}
\hline \multirow[b]{3}{*}{ NERC Regions(a) } & \multicolumn{3}{|c|}{ Summer Peak Load } & \multicolumn{3}{|c|}{ Net Energy for Load } \\
\hline & \multicolumn{2}{|c|}{ GW } & \multirow{2}{*}{$\begin{array}{l}\text { Annual } \\
\text { Growth } \\
\text { Rate, \% }\end{array}$} & \multicolumn{2}{|c|}{$\begin{array}{c}\text { Billions of } \\
\mathrm{kWh}\end{array}$} & \multirow{2}{*}{$\begin{array}{l}\text { Annual } \\
\text { Growth } \\
\text { Rate, } \%\end{array}$} \\
\hline & 1987 & 1997 & & 1987 & 1997 & \\
\hline ECAR & 72.6 & 83.0 & 1.6 & 409 & 473 & 1.5 \\
\hline ERCOT & 39.3 & 50.3 & 2.4 & 195 & 257 & 2.9 \\
\hline MAAC & 40.5 & 44.5 & 1.3 & 207 & 244 & 1.8 \\
\hline MAIN & 37.5 & 42.6 & 1.5 & 182 & 215 & 1.7 \\
\hline MAPP-US & 23.2 & 26.2 & 1.5 & 113 & 136 & 1.7 \\
\hline NPCC-US & 42.7 & 50.9 & 1.9 & 239 & 288 & 1.8 \\
\hline SERC & 109.8 & 137.3 & 2.4 & 574 & 721 & 2.4 \\
\hline SPP & 47.7 & 57.4 & 1.9 & 228 & 273 & 1.9 \\
\hline WSCC & 83.0 & 101.4 & 1.9 & 496 & 602 & 1.8 \\
\hline NERC-US Total & 496.2 & 593.7 & 1.9 & 2644 & 3210 & 2.0 \\
\hline \multicolumn{7}{|l|}{ Selected Subregions } \\
\hline S. Central Illinois (b) & 6.8 & 7.4 & 1.0 & 34 & 39 & 1.4 \\
\hline Florida $(c)$ & 25.7 & 33.1 & 2.9 & 125 & 174 & 3.3 \\
\hline Arizona-New Mexico(d) & 10.6 & 14.2 & 2.6 & 55 & 76 & 3.4 \\
\hline NW Pool ${ }^{(d)}$ & 25.7 & 29.3 & 1.2 & 186 & 215 & 1.1 \\
\hline
\end{tabular}

Source: NERC 87, pp. 11 and 16.
(a) NERC Regions are shown in Appendix C.
(b) Subregion of MAIN.
(c) Subregion of SERC.
(d) Subregion of WSCC. 


\section{PROJECTIONS OF THE NEED FOR NEW GENERATING CAPACITY}

SUMMARY

In this section, we project the long-term need for new generating capacity. Three scenarios were selected to represent the projected "most likely" situation and the high and low extremes. The most likely scenario is that national electricity demand will grow with the economy at an average rate of $2.5 \%$ year and that the plant service life will average 50 years. The high growth scenario combines a growth rate of $3.5 \%$ with a 40 -year plant life. The low growth scenario combines a growth rate of $1.5 \% /$ year with a 60-year plant life. Taking into account currently scheduled capacity additions, additional (currently unscheduled) capacity is required by 1992 under the high scenario, by 1995 under the middle scenario, and by 2000 for the low scenario. In all scenarios, once reserve margins, which are currently high, reach our assumed value of $20 \%$, annual requirements for new capacity additions increase to meet the combined growth rate and replacement rate requirements.

\section{CAPACITY PLANNING}

The need for new generating capacity comes from three sources: 1) the growth in peak demand, 2) the replacement of obsolete capacity, and 3) the need for reserve capacity. Generating capacity is added, as needed, to meet the projected peak demand; a reserve margin is added to ensure reliability. The determination of peak demand, reserve margin, and the replacement of obsolete capacity are described below.

\section{Peak Demand}

Although the growth in peak demand is the important variable for capacity planning, it is more difficult to forecast, because of its greater sensitivity to weather and end-use patterns, than the growth in annual electricity demand. However, over the long run the national peak demand and annual demand track each other rather closely (Figure 5). Over the period from 1960 through 1987 total growth in the peak load is only two percent more than the total growth in the annual electricity demand 


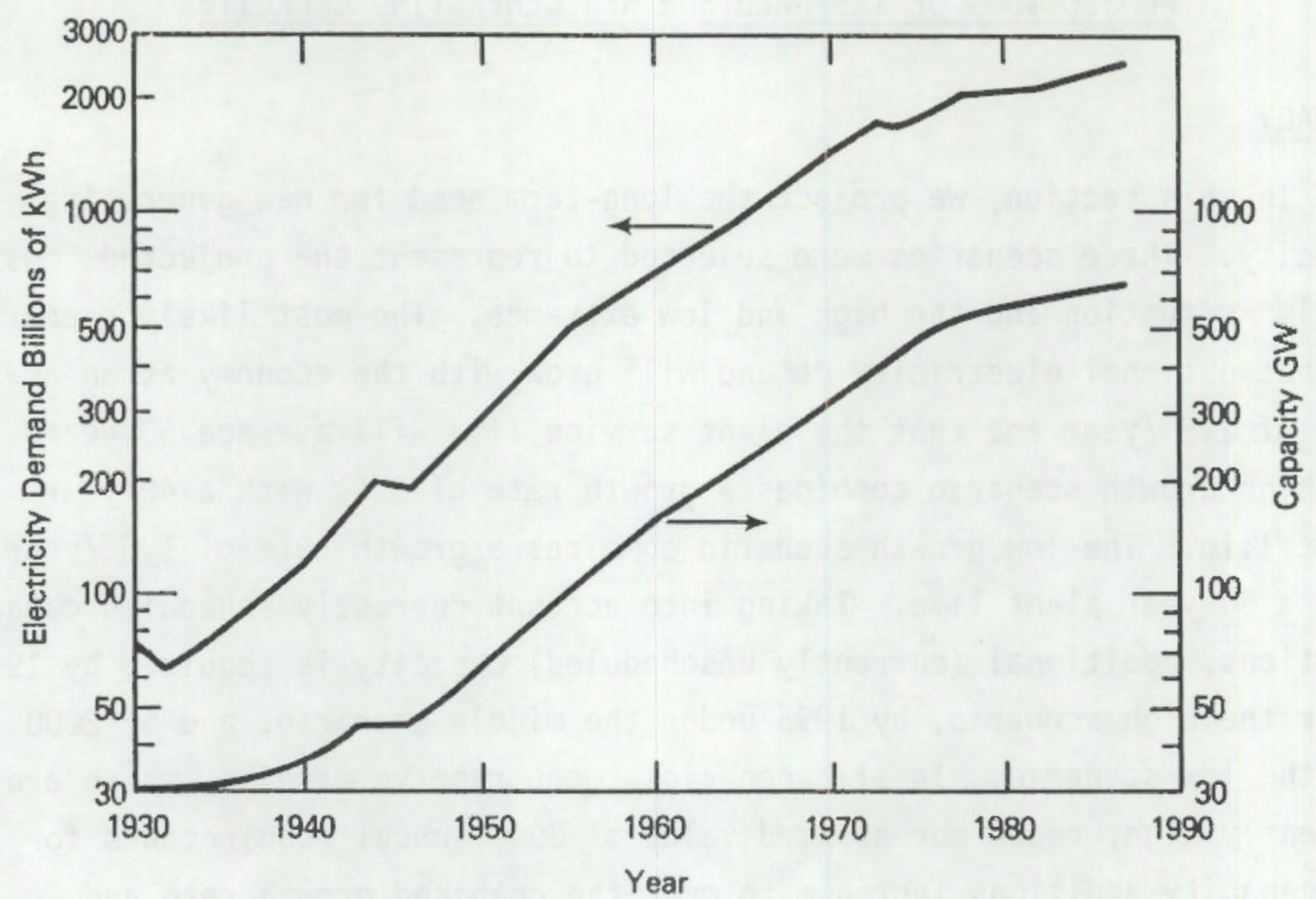

FIGURE 5. Historic Growth of Electricity Demand and Generating Capacity

(Figure 6). Thus, the forecasted growth in electricity demand, 1.5 to $3.5 \% /$ year, should be a good predictor of peak load growth and adequate for purposes of long range projection. Although the peak demand determines the amount of capacity needed, the shape of the annual demand, as reflected by the load duration curve, determines the type of capacity needed to meet reliability standards and achieve the lowest cost (see Appendix D). In this study we assume the shape of the load duration curves remains constant and thus the proportions of base, intermediate, and peak capacity remains constant.

\section{Reserve Margin}

The reserve margin is the installed capacity above that required to meet the peak load, expressed in percent, as (Capacity - Peak)/Peak. The margin allows for scheduled outages, forced outages, deratings, and higher than projected peak demands. To meet reliability criteria, a reserve margin 


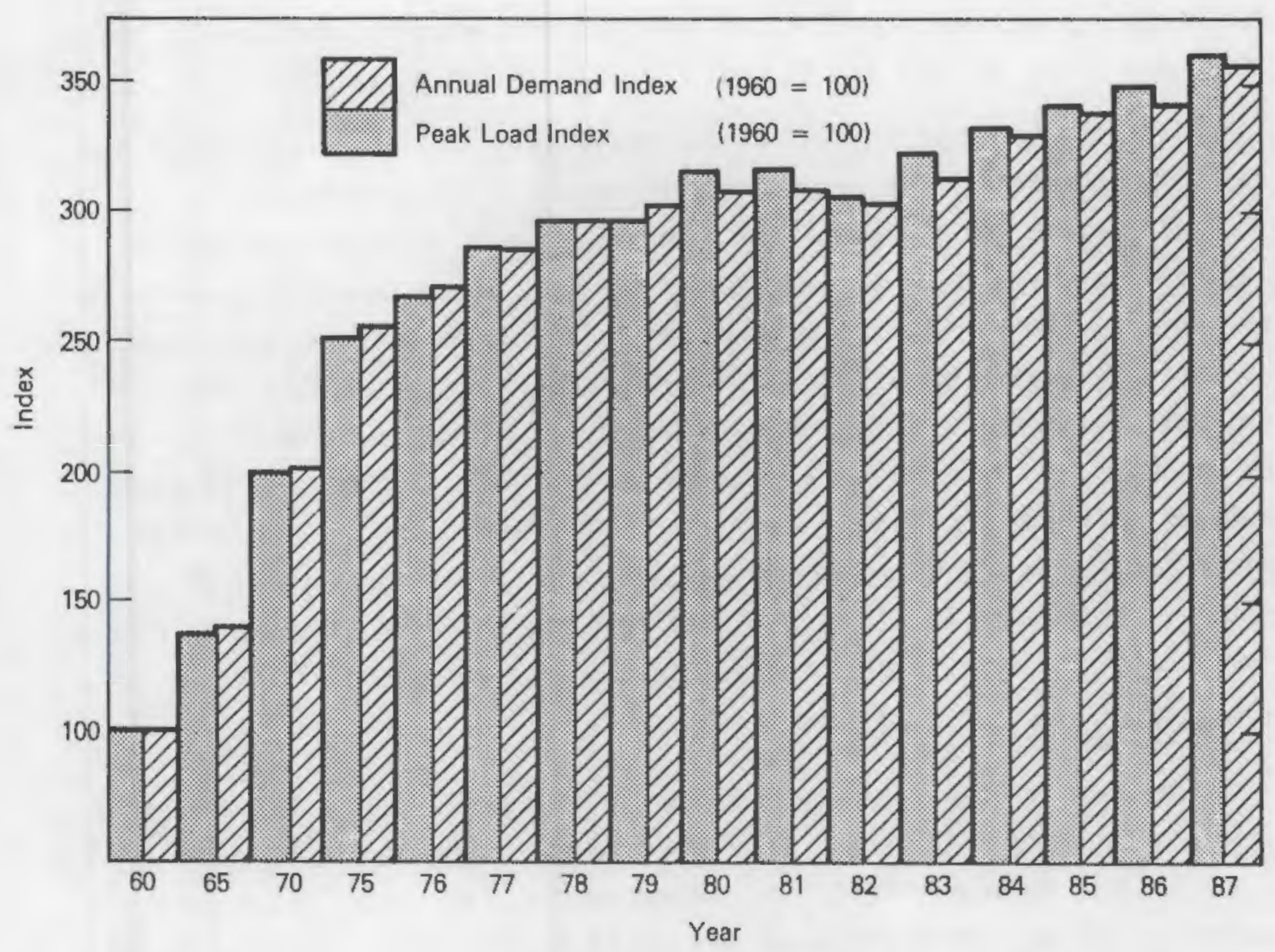

FIGURE 6. Variations in Annual National Peak Load and Energy Demand

of $20 \%$ has been the rule-of-thumb. (a) Although reserve margins have been much above this value in recent years, current utility planning is headed towards $20 \%$. Some suggest a reserve of about $25 \%$ margin (EW 85, p. 56). One study (EPRI 78, pp. S8-S11) indicates that the optimum reserve margin for some individual utilities may be about $30 \%$. On the other hand, advances in load management, time-of-day pricing, increases in plant reliability, and expanded regional interties may enable utilities to operate with lower

(a) The $20 \%$ rule-of-thumb for the reserve margin derives from a report by the Federal Power Commission (FPC), titled "The 1970 National Power Survey." The FPC concluded that a $20 \%$ reserve margin industry wide, might be advisable (Senate 85, pp. 1243-1244). 
reserve margins. The lowest and highest reserve margins, nationwide, since 1953 were $16.6 \%$ in 1969 (Hy 85, pp. 85, 103) and 39.9\% in 1982.

The term "reserve margin" can be misleading. A large fraction of the capacity included in the reserve margin is typically unavailable (out-of-service) at the peak load. The "available" reserve capacity is the critical measure of reliability at the peak load. A recent article on reliability (EPRI 86, p.10) showed that 15 to $18 \%$ of capacity was unavailable at the peak load (Figure 7). In 1983, for example, the capacity margin (a) was $25 \%$. However, at the peak $6 \%$ of the capacity was down for maintenance, $6 \%$ was down for forced outages, and $3 \%$ was not available because of partial outages and derating. Thus, $15 \%$ of the capacity was unavailable at the peak, leaving an operating margin (available reserve capacity) of $10 \%$. This is illustrated in Figure 7. Note that the percentages shown in Figure 7 refer to the capacity margin and not to the reserve margin.

Retirement of Obsolete Capacity

The need for new capacity additions also depends on the retirement of obsolete capacity. Although the average service life of plants retired since 1970 is 36 years, utilities are currently undertaking plant life extension and upgrading programs that could extend plant life to 50 to 60 years at a fraction of the cost for new capacity. As indicated earlier, the planned rate of retirements through 1996 is consistent with the rate of plant additions 50 to 60 years earlier. Therefore, an average service life ranging from 40 to 60 years reflects recent experience and current trends. The need for new capacity to replace obsolete capacity can readily be determined for future years for various service life assumptions.

The rate of peak load growth and the average service life combine to determine the need for annual capacity additions. In the past, when electricity demand was growing at $7 \%$ per year and the average service 1 ife was 36 years, the replacement rate for obsolete plants was only $9 \%$ of the annual capacity addition. However, in the future with demand growing at

(a) The capacity margin is expressed in percent as (capacity - peak)/capacity.

(b) The reserve margin $(\%)$ is equal to capacity margin $(\%) /(1$ - capacity margin $(\%) / 100)$. 


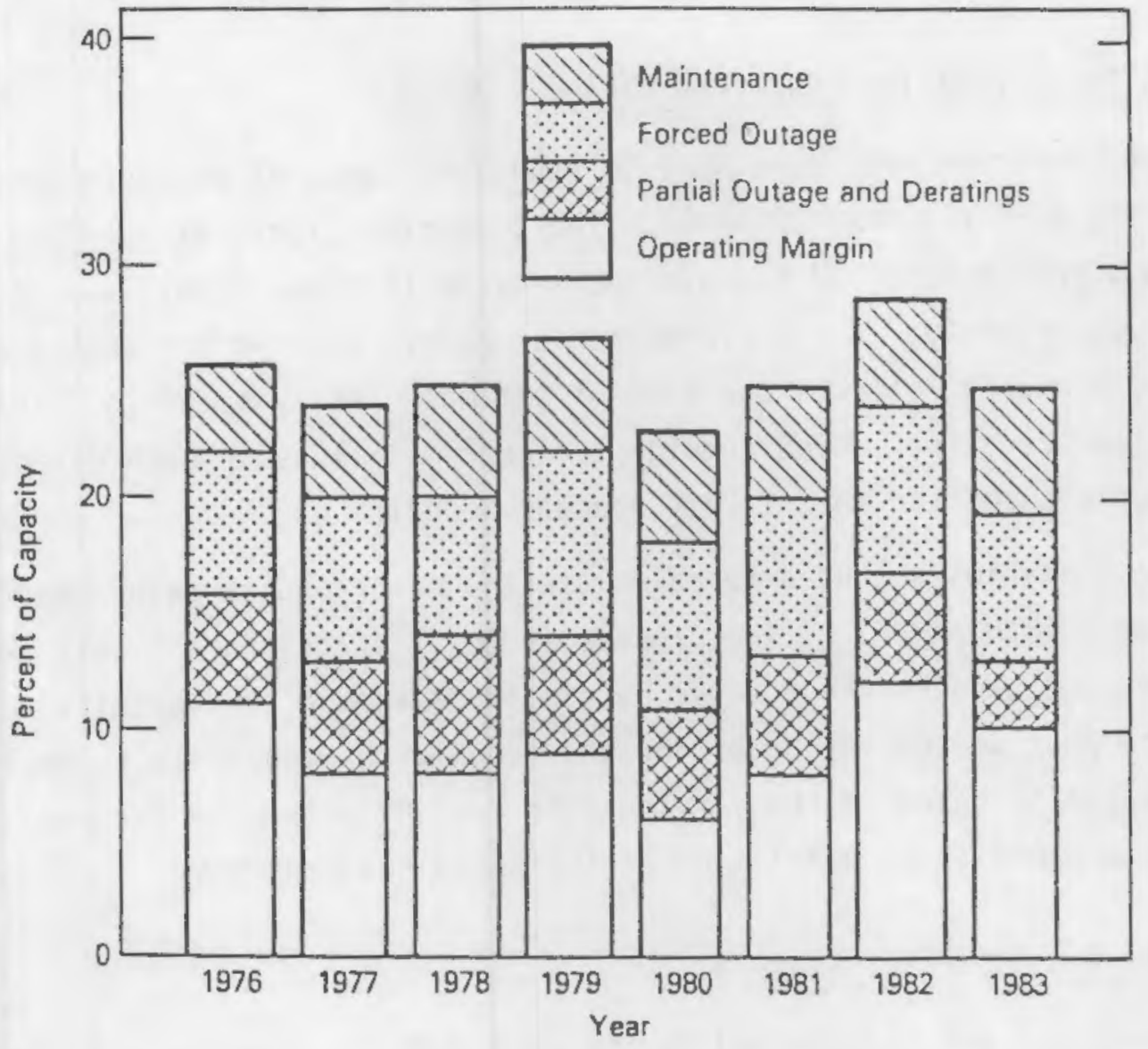

FIGURE 7. Effect of Availability on Margins (a)

Note: Providing reliable electric service requires having reserve capacity actually available when needed. A distinction must therefore be made between the theoretical capacity margin usually quoted and the operating margin provided by readily available plants. During 1983, for example, demand for electricity reached only $75 \%$ of utilities demonstrated capacity, but $15 \%$ of capacity was sometimes unavailable because of preventive maintenance, forced outages, and other causes leaving an actual operating margin as low as $10 \%$ during the summer demand peak.

(a) EPRI 86, p. 10 .

only $2.5 \%$ per year and the average service life at 50 years, the equilibrium replacement rate for obsolete capacity increases to $29 \%$ of the annual capacity addition. However, with the transition from the $7 \%$ to $2.5 \%$ growth rate, which occurred in 1973, the replacement rate should gradually increase 
to over $40 \%$ of the annual capacity addition (assuming a 50 -year service life) before the equilibrium rate of $29 \%$ is established.

\section{SCENARIOS FOR ESTIMATING LONG-TERM CAPACITY NEEDS}

Three scenarios were developed to study the range of probable needs for new capacity over the next 50 years. The scenarios (Table 3) vary the peak demand growth rate and the average service life over their expected ranges of uncertainty. A reserve margin of $20 \%$ is assumed for each scenario. The middle scenario reflects our view of the most likely scenario. The high and low scenarios, which combine the extreme values in each direction, reflect our view of the most likely boundary conditions.

These scenarios are used to calculate the new capacity requirements for each year through 2037. The process is to 1) calculate the peak demand in each year, 2) add on the reserve margin to determine the capacity required to meet the peak demand, 3) determine the need for new capacity to replace obsolete capacity based on the service life, and 4) determine the need for new baseload capacity as a fraction of the total new capacity.

\section{PEAK DEMAND PROJECTIONS TO 2037}

We projected the peak demand to the year 2037, assuming growth rates of $1.5,2.5$, and $3.5 \%$ (Figure 8 ). Even at these historically low growth rates the difference between the high and low peak demands increases rapidlyreaching $100 \mathrm{GW}$ by 1996 and growing to $1700 \mathrm{GW}$ by 2037. This provides a startling measure of the magnitude of the uncertainties in future electricity demand, considering the fact that total capacity in 1988 is $658 \mathrm{GW}$.

TABLE 3. Scenarios for Determining Capacity Requirements

\begin{tabular}{|c|c|c|c|}
\hline Scenario & $\begin{array}{l}\text { Peak Demand } \\
\text { Growth Rate } \\
(\% / \text { Year) }\end{array}$ & $\begin{array}{l}\text { Average Service } \\
\text { Life of Power } \\
\text { Plants (Years) }\end{array}$ & $\begin{array}{l}\text { Reserve } \\
\text { Margin } \\
(\%) \\
\end{array}$ \\
\hline High-Demand & 3.5 & 40 & 20 \\
\hline Middle-Demand & 2.5 & 50 & 20 \\
\hline Low-Demand & 1.5 & 60 & 20 \\
\hline
\end{tabular}




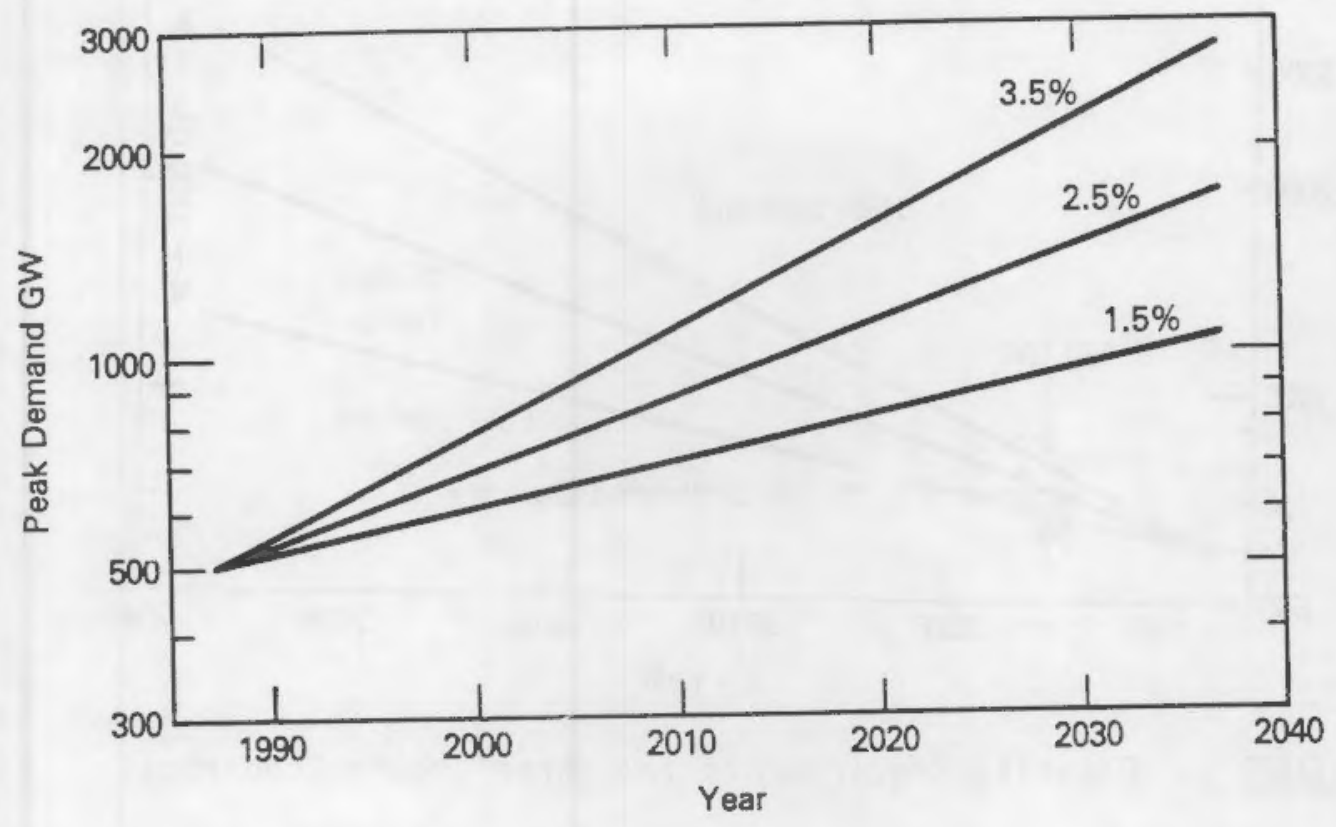

FIGURE 8. Projected Peak Demand for Three Growth Rates

\section{TOTAL CAPACITY REQUIREMENTS}

The capacity requirements (Figure 9) for each of these scenarios are obtained by adding a $20 \%$ reserve margin to the peak demand (see Appendix E for tabular data for selected years from which Figures 8 to 12, 14, and 15 were derived and for the complete year-by-year tabulation of capacity projections when both NERC plans and our scenarios are considered). By 1996, the difference in capacity requirements between the high and low scenarios grows to $130 \mathrm{GW}$; this increases to $2100 \mathrm{GW}$ in 2037.

The planned capacity in 1996 by NERC is 716 GW (NERC 87). This capacity is required in 1993 for the high scenario, in 1995 for the middle, and not until 2000 for the low scenario. Under the high scenario, construction would need to be accelerated for plants now under construction or new 


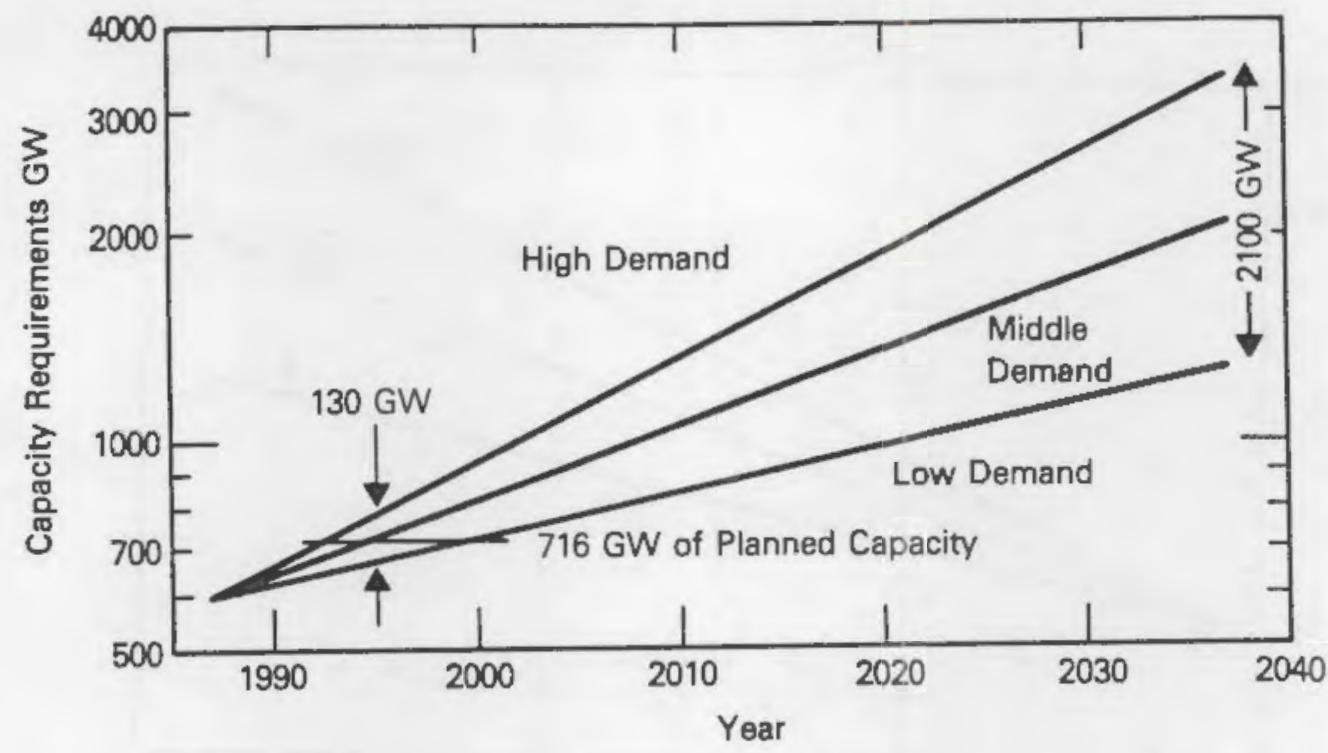

FIGURE 9. Capacity Requirements for Three Growth Scenarios

capacity commitments would need to be made soon. (a) The middle scenario corresponds closely to current capacity expansion plans. Under the low scenario, current capacity expansion plans would need to be stretched out about 5 years.

The incremental capacity requirements to meet projected load growth for each scenario over the 716 GW currently planned for 1996 are shown in Figure 10. The requirements under the high scenario exceed $2500 \mathrm{GW}$ in 2037. Because of the scale needed to show the high scenario, the large requirements for new capacity in the earlier years may appear deceptively small. For perspective, keep in mind that each GW represents one large modern plant. For example, the middle scenario required an additional

(a) Since new baseload capacity requires a lead time of eight to ten years, additional capacity requirements prior to 1996 would have to be smaller units, such as gas turbines, that could be installed more quickly. Other possibilities for the near term are upgrades of existing plants, power purchases, and phase-ins of combined cycle plants. The recent growth rate has been about in line with the middle scenario, indicating that a pick up in the orders for new baseload capacity should occur within a few years. 


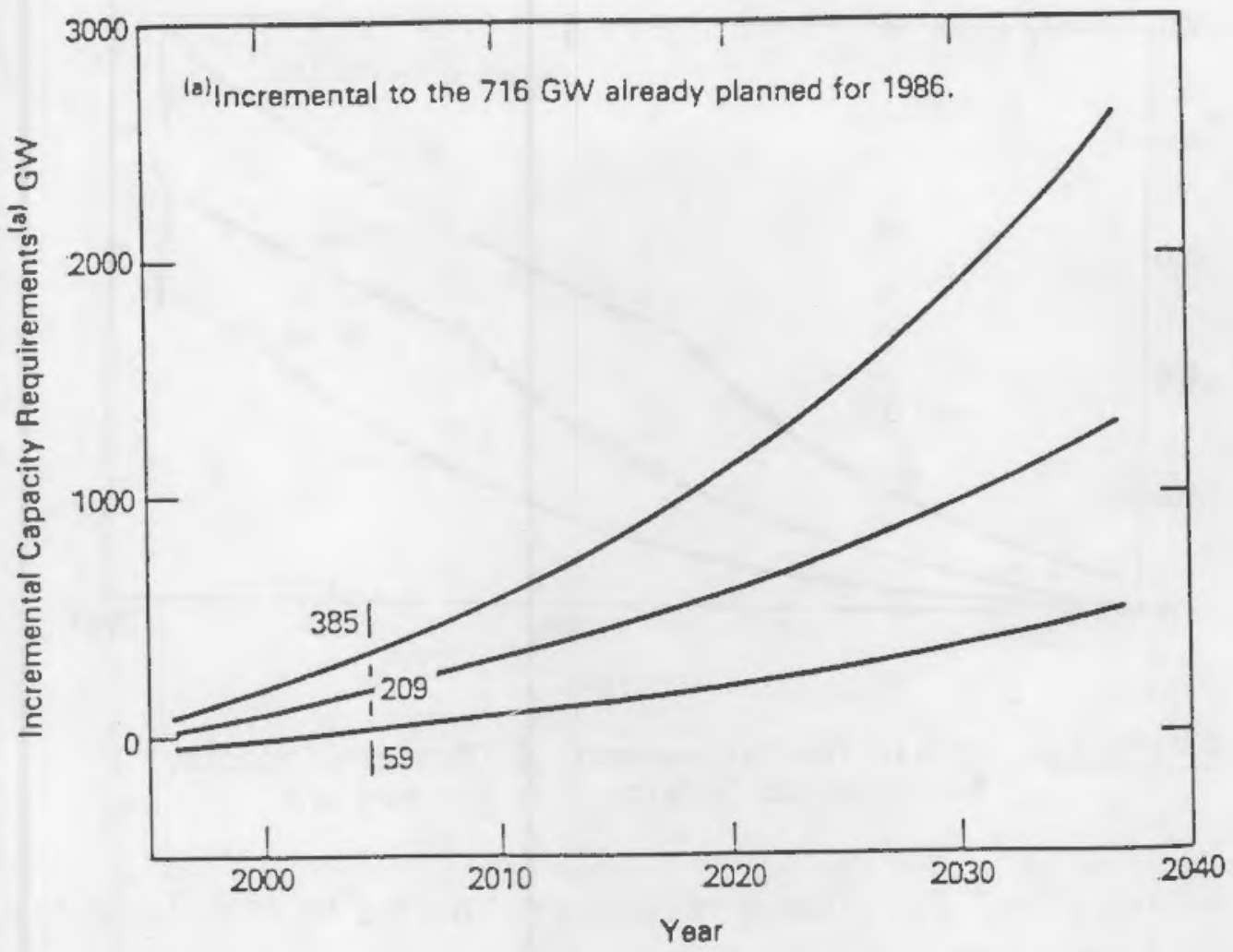

FIGURE 10. Incremental Capacity Requirement for Three Growth Scenarios

209 GW by 2005, the high scenario required an additional 385 GW by 2005 , and the low scenario required 59 GW more by 2005 .

The total new capacity requirements to meet both load growth and the need to replace plants are obtained by adding the retired capacity to the incremental capacity requirements shown in Figure 10 . The cumulative retirements of obsolete capacity for each service life assumption are shown in Figure 11. Retirements are based upon the capacity additions that were made one service life earlier. The additions through 1984 were derived from the historical capacities given by EIA scaled by the ratio of the NERC capacity to the EIA capacity in 1984 (604/672). After 1984 the additions were calculated from the planned capacity increases reported by NERC or required by our scenario, if that was larger, plus the retirements. Figure 11 illustrates the substantial impact of the service life assumption on the need for new capacity; that is, 143 GW more capacity is required by 2005 to replace obsolete plants assuming a 40 year service life than for a 


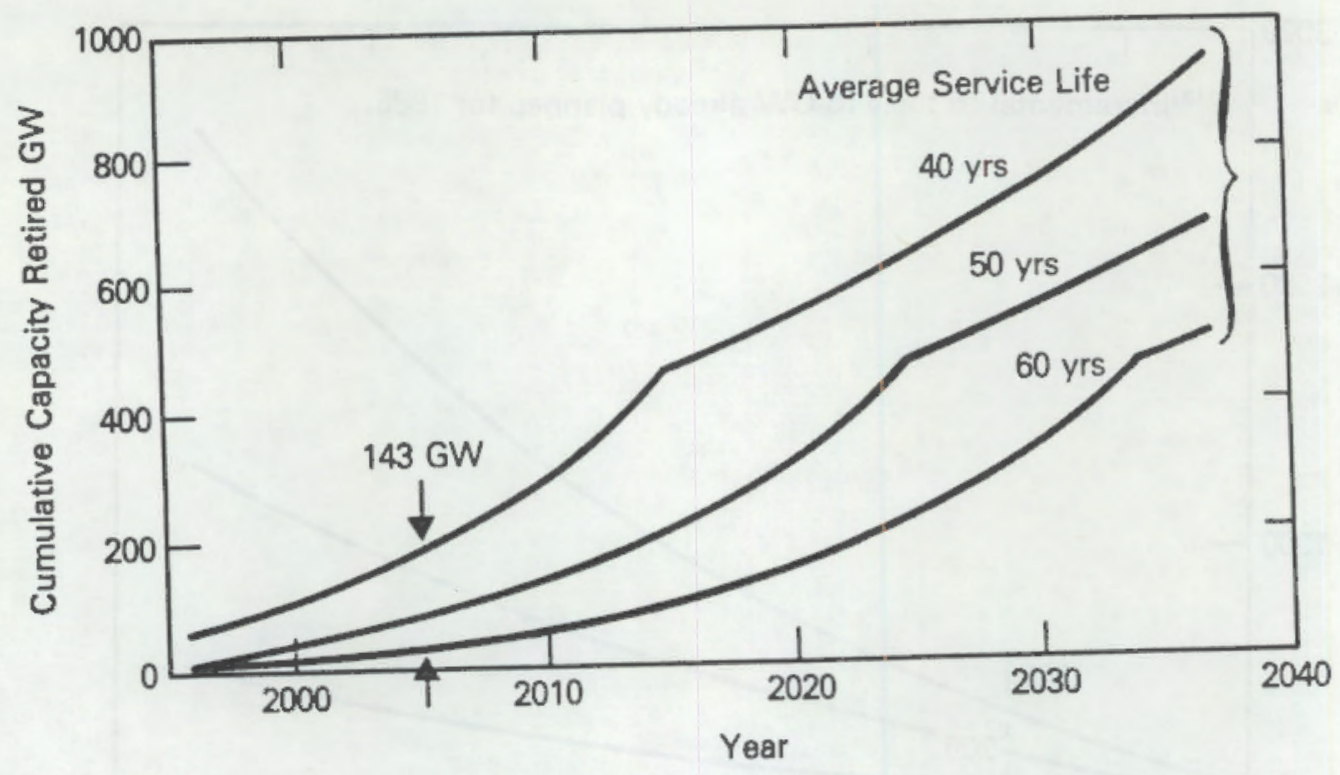

FIGURE 11. Cumulative Retirements of Obsolete Capacity for Selected Service Life Assumptions

60 year service life. The planned retirements to 1996 by NERC (NERC 87) are $11 \mathrm{GW}$; this corresponds most closely to the 60 year service life assumption. Also, note the knee in the curves reflecting the transition from the higher to the lower growth rate in capacity additions that occurred in 1973.

The total new capacity requirements (Table 4) are obtained by adding Figures 10 and 11 and subtracting $11 \mathrm{GW}$ for the planned retirements that are already included in the 716 GW planned by NERC for 1996.

The need for new baseload capacity (Figure 12) is estimated to be about $60 \%$ of the total new capacity requirements. The need for new baseload capacity determines the potential need for new nuclear or coal plants. The cumulative need for new baseload capacity to year 2037, over and above the 716 GW capacity already included in NERC plans through 1996, ranges from $601 \mathrm{GW}$ in the low scenario to $1156 \mathrm{GW}$ in the middle scenario to $2067 \mathrm{GW}$ in the high scenario. Note that the difference between the high and low scenarios exceeds 200 GW by 2000 . 
TABLE 4. Cumulative Incremental Need for New Capacity (a) (GW) for Both Load Growth and Replacement of Obsolete Capacity for Selected Years

\begin{tabular}{|c|c|c|c|}
\hline Scenario & 1996 & 2005 & 2037 \\
\hline High Demand & 143 & 534 & 3445 \\
\hline Middle Demand & 26 & 269 & 1928 \\
\hline Low Demand & $(40)$ & 70 & 1002 \\
\hline
\end{tabular}

(a) Above the currently planned capacity of $716 \mathrm{GW}$ in 1996.

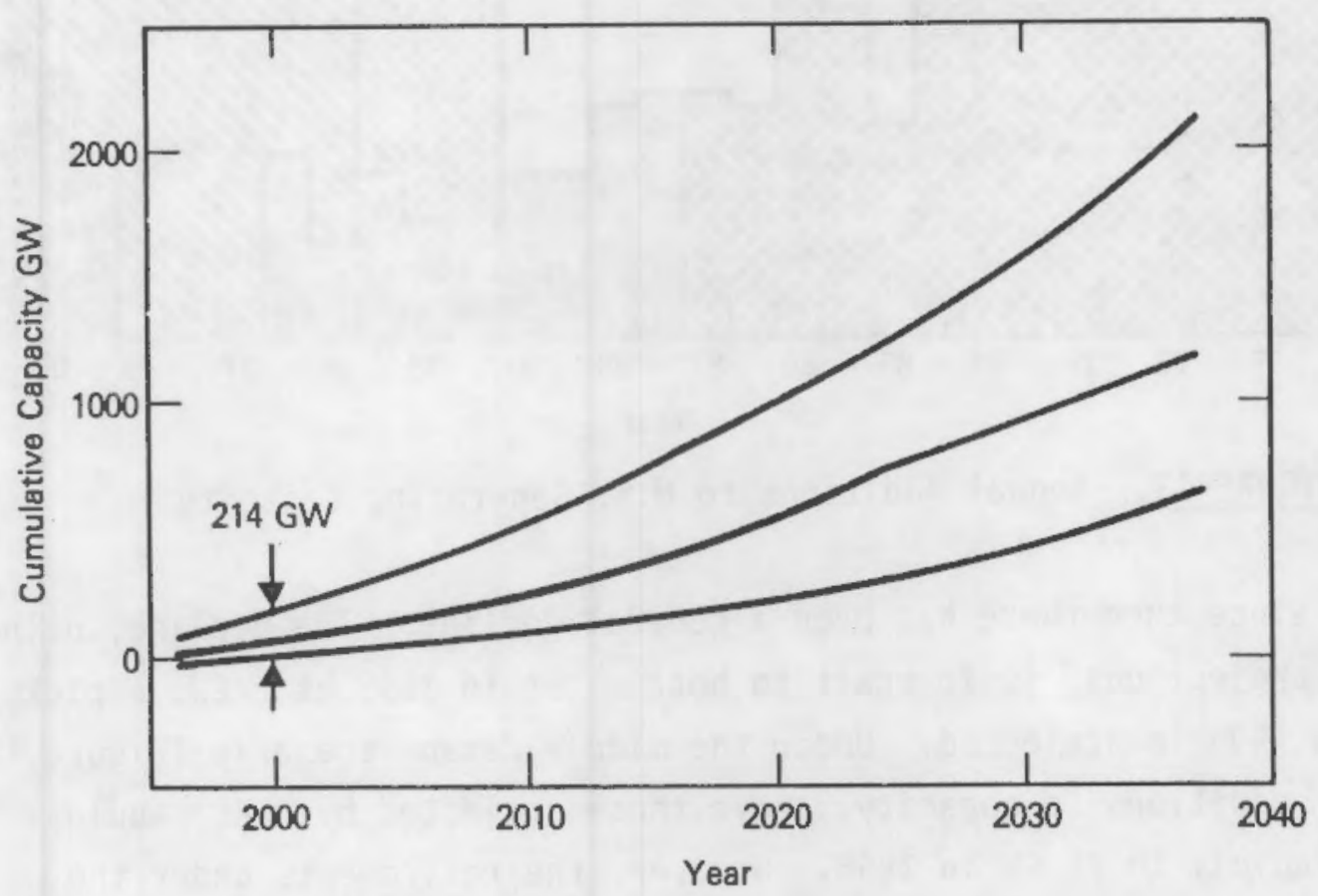

FIGURE 12. Cumulative Need for New Baseload Capacity for Three Growth Scenarios

\section{ANNUAL REQUIREMENTS FOR NEW CAPACITY}

Turn now to the annual requirements for new capacity to meet load growth, retirements, and reserve margins. For perspective, consider the steep decline in the annual additions to capacity and the prospects for recovery (Figure 13). The largest additions to capacity, $44 \mathrm{GW}$, occurred 


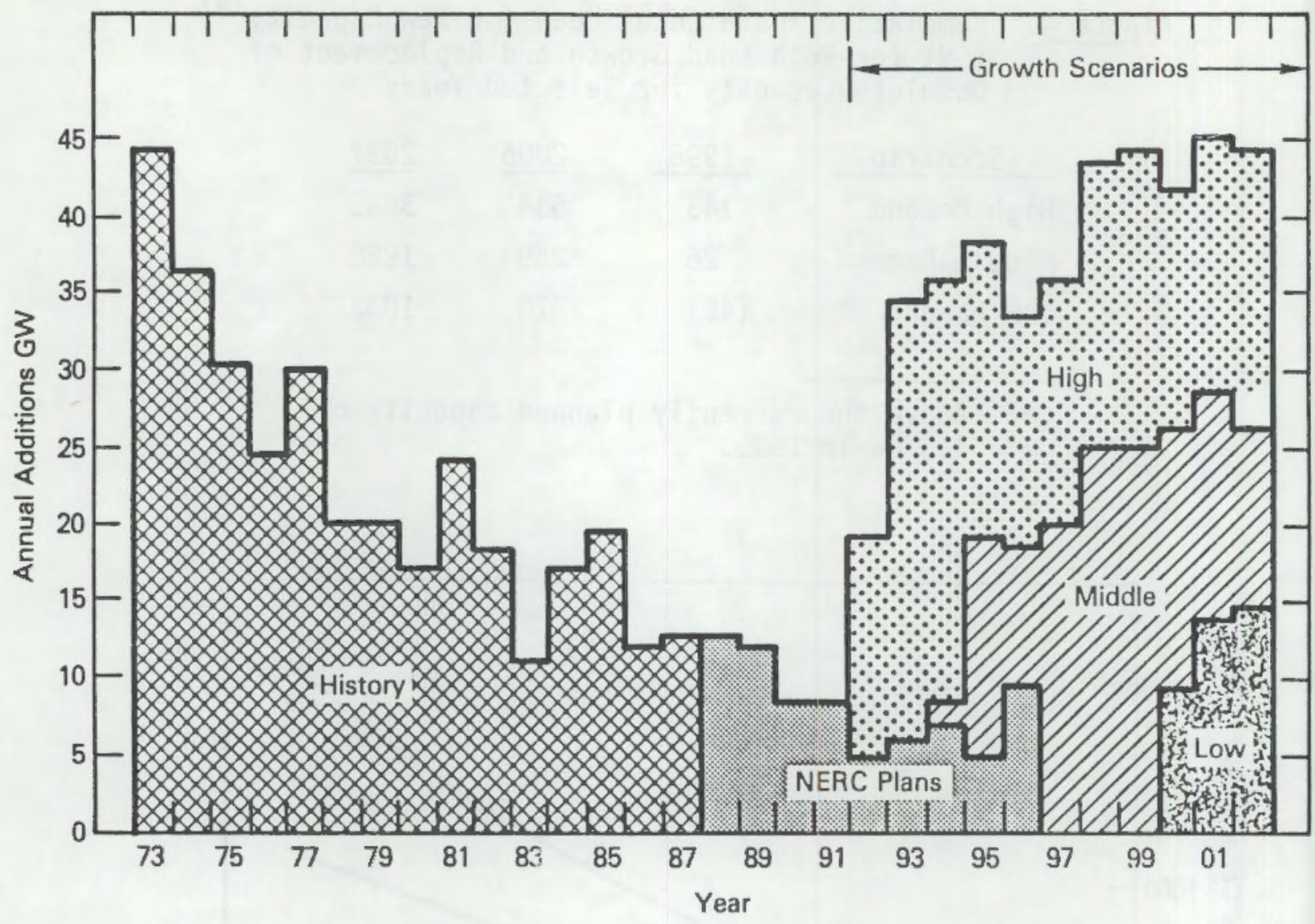

FIGURE 13. Annual Additions to U.S. Generating Capacity

in 1973. Since then there has been a general decline. The decline, using NERC 1987 projections, is forecast to bottom out in 1995 at $5 \mathrm{GW}$, a pickup to $9 \mathrm{GW}$ in 1996 is projected. Under the middle demand scenario (Figure 13), the annual additions to capacity, above those projected by NERC, would increase rapidly to $25 \mathrm{GW}$ in 1998 . However, the retirements under the 50-year service life assumed in the middle demand scenario are higher than the retirements planned for the 10 preceding years. Thus, if a longer service life does prevail (e.g., 60 years), the annual capacity additions would be about $5 \mathrm{GW}$ smaller than shown. Nonetheless, annual capacity additions would increase to over $20 \mathrm{GW}$ by the year 2000 . The high scenario requires a few additional plants in 1992, and over 35 GW per year from 1993 onward. The low scenario does not require additional plants until 2000. NERC plans, as shown in Figure 13, are intermediate between the low 
and middle scenarios; NERC 1987 projections were for a $2.1 \%$ growth which was revised to $2.0 \%$ growth in 1988 .

The annual requirements for the three scenarios are summarized for selected years in Figure 14. For example, 44 GW of new capacity are required in the year 2005 under the high demand scenario. Keep in mind that approximately $44 \mathrm{GW}$ are also required in 2006, 2007, etc., since these are annual requirements. The annual requirements are somewhat erratic in that the retirements in a given year reflect historical plant additions. For instance, the high requirements in 2025 for the middle scenario is caused by replacing plants that began service in 1975 according to the assumed 50-year retirement schedule for this scenario. Plant additions in 1975 were unusually high compared to the succeeding years.

The total new capacity requirements include the need for peaking capacity, load-following capacity, and baseload capacity. We estimate the annual need for new baseload capacity (Figure 15) to be approximately $60 \%$ of the total new capacity requirements previously shown in Figure 14.

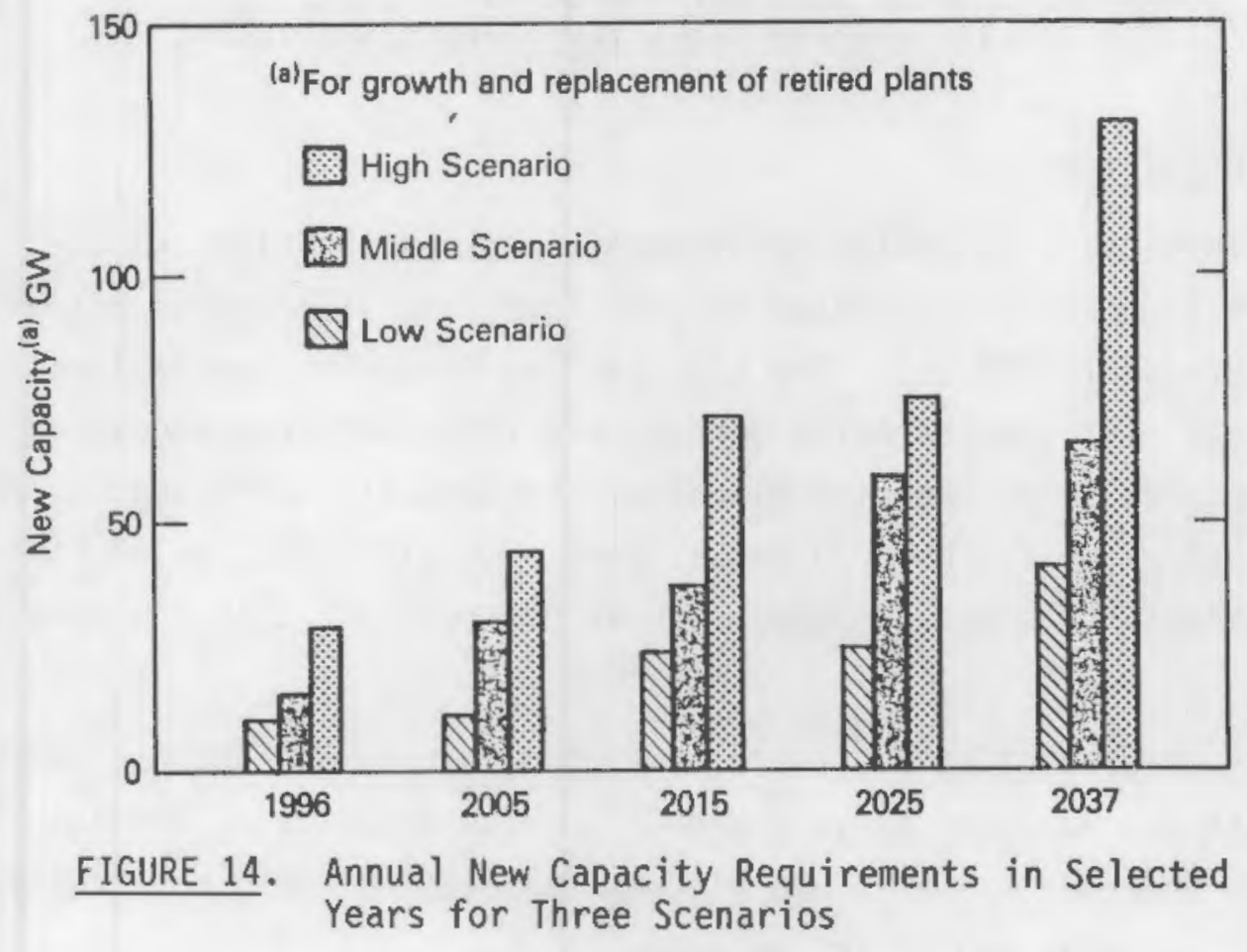




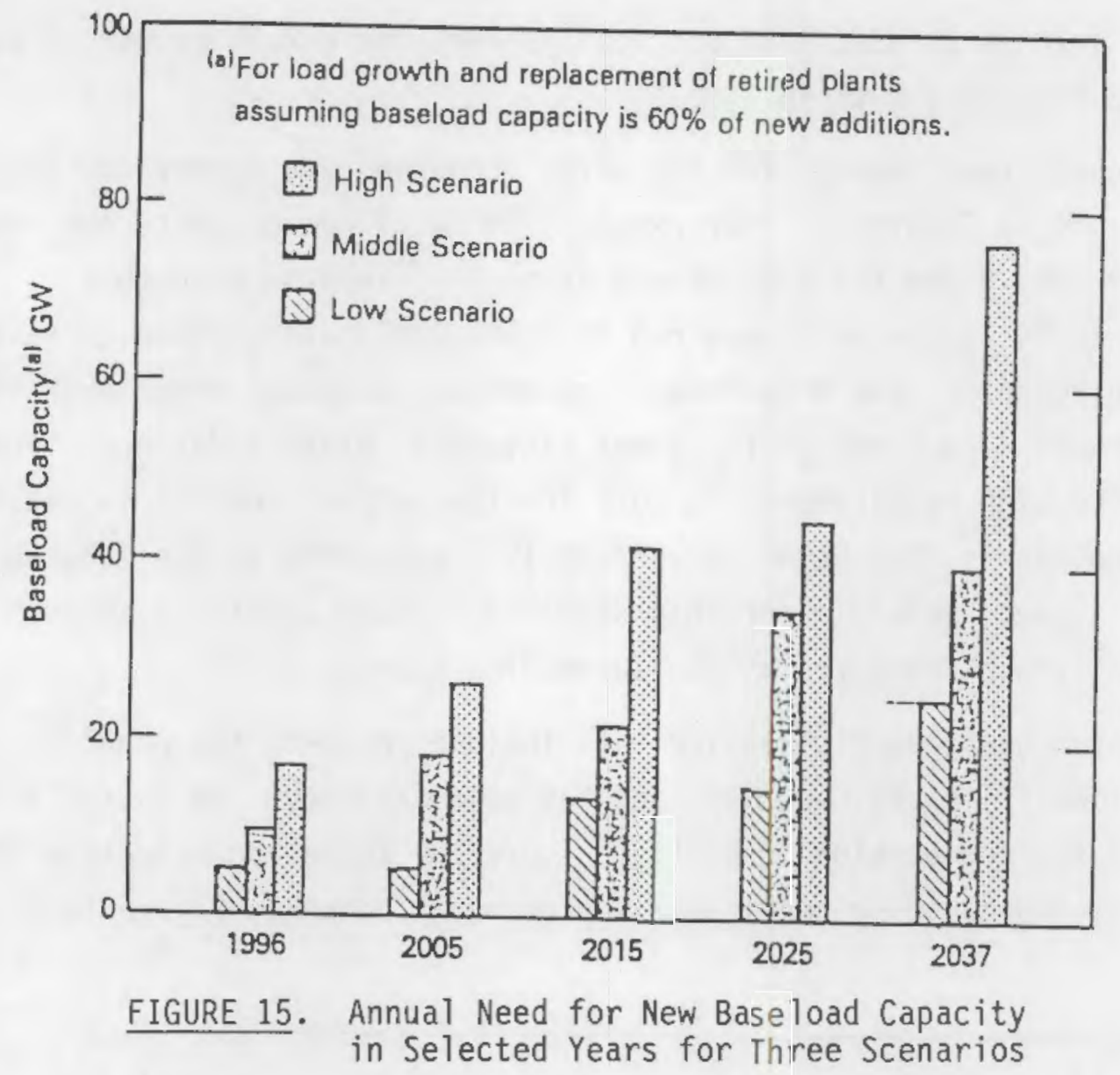

\section{Planning Uncertainties}

The differences in capacity requirements between the high and low scenarios are enormous. Translated into dollars, the differences reach into the hundreds of billions. The high and low scenarios, we believe, bound the range of future capacity demands and illustrate the magnitude of the uncertainties facing capacity planners. Fortunately, planning horizons are shorter and plans can be adjusted as events unfold. But, as we have seen, adjustments to abrupt changes, such as occurred in 1973, can take a long time.

Planning uncertainties deal with demand and supply projections and what drives them. Apparent drivers are GNP, price elasticity, and inter-fuel competition. Underneath lies a web of complex relationships, constantly changing with economic and social activity. 
One of the obvious factors that affects uncertainty is the length of the lead time between the capacity addition decisions and plant startup. The rate of divergence (2\% per year) between the low and high projections provides a measure of the relationship of uncertainty to lead time. For instance, for each year the lead time is shortened or lengthened, the uncertainty in the capacity requirements for a future target year is reduced or increased, respectively, about two percent, or about 14 GW currently.

\section{IMPORTANCE OF LONG-TERM AND NEAR-TERM PROJECTIONS}

Near-term and long-term projections serve different purposes. Nearterm projections are essential to power plant construction and conservation decisions. Long-term projections are essential for strategic planning purposes in order to foster the timely development of suitable technologies, to ensure the availability of sufficient and secure energy supplies, and to develop policies that protect against severe economic disruptions.

Accurate near-term projections are essential in order to avoid the economic and social costs that can be caused by either shortages of efficient generating capacity or by an excess capacity of capital-intensive plants. New baseload capacity, using existing coal or nuclear technology, now requires a lead time of 8 years or more for licensing and construction. Inaccurate near-term projections on the low side could result in suppliers having to utilize inefficient high cost power sources or in consumers experiencing power shortages. Inaccurate projections on the high side could result in over-building, and subsequent underutilization, of capitalintensive plants. As demonstrated in the recent past, over-building can threaten the financial viability of the utilities involved and can have a dramatic impact on rates charged to the consumers.

The absolute accuracy of long-term projections is not as important as for near-term projections, assuming that projections are frequently updated and that energy supply strategies and associated R\&D programs are appropriately re-evaluated to reflect changes in projections. However, it must be recognized that if there is a large mismatch between long-term projections and realizations, then strategies developed for meeting long-term needs 
may not be appropriate. For example, over-prediction of electricity demand growth rates in the early 1970s led to supply strategies directed toward an early introduction of both nuclear breeder reactors and recycling of uranium in light-water reactors (LWR). Similarly, under-prediction of future demand could result in non-optimum supply strategies and the unavailability of sufficient resources and new technology to meet future needs. 


\section{SUPPLY OPTIONS}

\section{GENERATION PATTERNS}

The electricity generated in 1987 came from coal (55\%), nuclear (17\%), hydro $(9 \%)$, natural gas $(10 \%)$, petroleum $(4 \%)$ and other sources $(5 \%)$ (Figure 16). Other sources include non-utility generation, net imports, geothermal, solar, refuse, and wood.

The trends in electricity production by fuel type show substantial variations over time although year to year changes are slight. The actual and forecast trends in fuel mix as a percent of total generation is illustrated in Figure 17. From 1960 to 1971 the coal contribution declines from $55 \%$ to $44 \%$, being displaced by oil. Coal generation then remains relatively constant until 1978 and then increases back to $53-55 \%$ through 1996. 0il generation grows substantially from $6 \%$ in 1960 to $16 \%$ in 1973 , in response to the low oil prices during this period. The oil share remains on a plateau until 1978, from which it declines steadily to $4 \%$ today and remains at $3-4 \%$ through 1996 . Hydroelectric generation has steadily declined

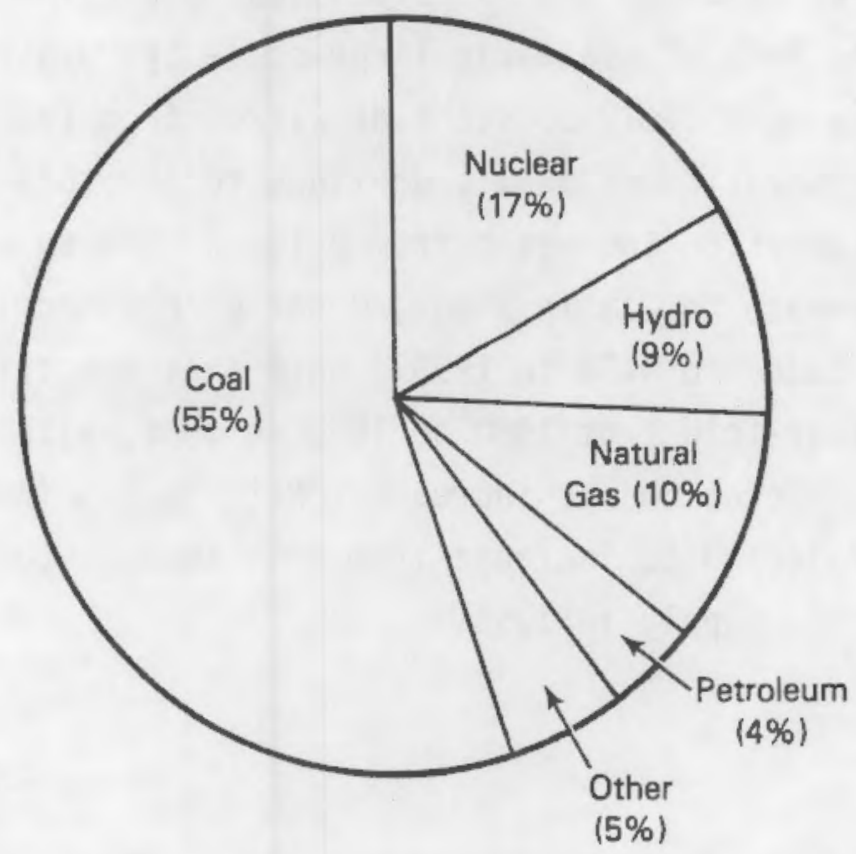

FIGURE 16. Electricity Generation by Fuel Type (1987) 


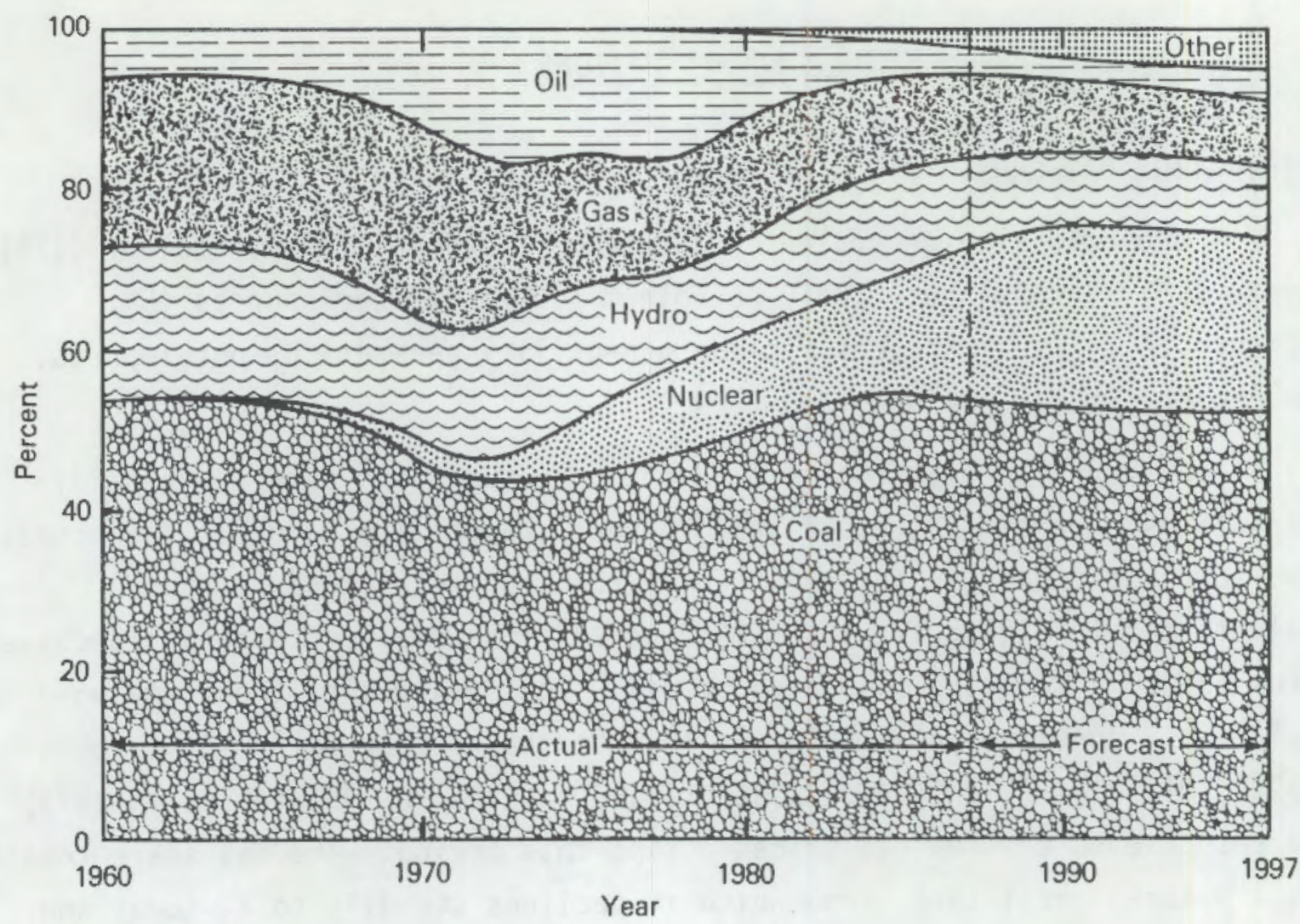

FIGURE 17. Electricity Production by Fuel Type

from $19 \%$ in 1960 to $9 \%$ today and is forecasted to decline to $8 \%$ in 1996 , in response to the lack of available large-scale hydro sites. Natural gas generation remains relatively constant at 21-24\% from 1960 through 1972, following which generation gradually declines to $10 \%$ today and to $9 \%$ in 1996. Nuclear generation increases from $0.1 \%$ in 1960 to $17 \%$ today and is forecasted to increase to $21 \%$ in 1996 . Other generation is projected to increase from $3 \%$ today to $4.5 \%$ in 1996 . Note that electricity generation increases about four-fold from 1960 to 1996 so that, although a fuel share may drop, actual generation may increase. Net imports (not shown in Figure 17) are projected to increase from less than $2 \%$ today to $4 \%$ of the domestic electricity supply in 1996. 


\section{CAPACITY}

In 1987 (NERC 87), coal-fired units had the largest capacity (286 GW), followed by nuclear ( $85 \mathrm{GW})$, conventional hydro (70 GW), dual (oil/gas) $(68 \mathrm{GW})$, oil ( $58 \mathrm{GW})$, gas ( $54 \mathrm{GW})$, and other (27 GW) (Figure 18). The capacity data represents the summer capability.

From 1987 through 1996, 85 GW of new capacity is scheduled to be added and $11 \mathrm{GW}$ is scheduled to be retired for a net addition of $74 \mathrm{GW}$. Most of this new capacity is comprised of coal ( $26 \mathrm{GW}$ ), nuclear (28 GW) and other (13 GW). Should additional capacity be.required, smaller blocks of peaking capacity, such as gas turbines, would be brought in quickly, perhaps as part of a staged-construction, combined-cycle plant (ED $86, p .1$ ).

\section{FUTURE SUPPLY OPTIONS}

The future electricity supply is expected to come from many sources, but only coal and nuclear currently have the extensive domestic reserves and proven technology to reliably provide large blocks of economic power.

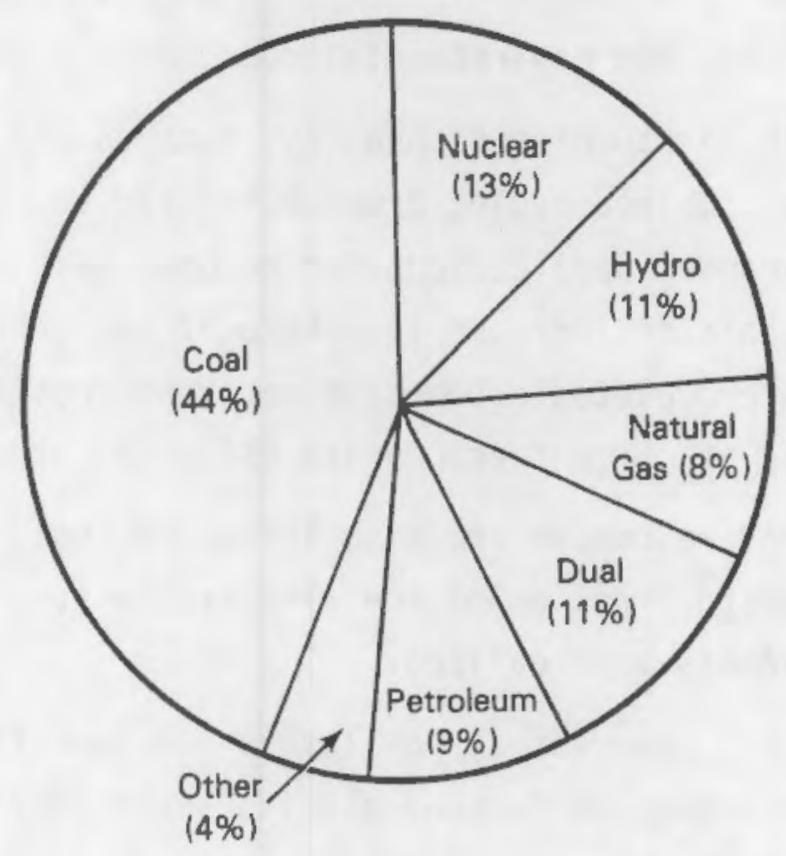

FIGURE 18. Generating Capacity by Fuel Type (1987)

Note: Dual uses either natural gas or petroleum. 
However, since new developments frequently alter the competitive situation, pursuing diverse energy options is advantageous and avoids dependency on a single option.

Many improvements in both coal and nuclear technology are on the horizon that address concerns over expanded use of these fuels. For example, 1) new developments in clean coal technology and recent experience in coal gasification offer promise to alleviate some of the environmental drawbacks to expanded coal usage and 2) improvements in LWR designs and new developments in liquid metal reactors and HTGRs offer promise to sharply reduce safety and risk concerns over nuclear power plants. Therefore, under foreseeable conditions, including the potential for improved technology, the future electricity supply is expected to be generated primarily by coal and nuclear baseload plants.

In addition, the existing large hydroelectric plants have an indefinite life and should continue to generate electricity at or above their current levels. Since few new large scale sites are available, the percentage of hydro's contribution should drop as electrical usage expands. However, small scale hydro has the potential to make a significant contribution if it becomes competitive, and environmental concerns are satisfied.

Advancements in gas turbine technology, such as the steam-injected gas turbine and the combined cycle, promise to lead to large efficiency improvements and expanded applications for natural gas. This should enable natural gas to maintain or increase its share of the generation until the low cost reserves are depleted. Domestic gas resources are large and gas reserves recoverable at current prices are estimated at nineteen years.

Renewable energy resources are also large and could provide a significantly increased fraction of the electricity supply if breakthroughs in their competitiveness are realized.

With domestic oil reserves at low levels and imports running high, oil generation should decline further and its share of electricity production should continue to drop. 
Fusion energy, although a potentially inexhaustible source of electricity, appears to be at least 30 years away from significant commercial use.

Canadian imports are expected to increase and become a more important source of supply, particularly in the Northeast. However, for reliability reasons imports are unlikely to become a dominant percentage of a system's load.

Conservation is also a potential supply option. The sharp decrease in the electricity growth rate beginning in 1973 is attributable to conservation. Conservation has not played as important a role in electricity usage as in overall energy usage. A crude measure of conservation is the productivity of electricity as measured by the ratio of real GNP to electricity generation. There has been only a slight increase (3\%) in this ratio over the last decade. In contrast, the ratio of real GNP to overall energy consumption has increased about $30 \%$ over the same period (Hy 85, p. 101). The slight increase in electricity productivity was probably caused by shifts in the economy away from electricity consuming industries. A potentially larger improvement in productivity was partially offset by substitution of electricity for primary energy in some industries. Decreases in electricity consumption per unit of output did occur in the top four electricity intensive industries, chemicals, paper, primary metals, and food processing. 



\section{RESOURCE CONSUMPTION AND WASTE PRODUCT GENERATION}

\section{SUMMARY}

This section estimates the coal and nuclear fuel consumption and resulting waste generation for the three growth scenarios studied in the preceeding section. For each scenario we examine the consequences of pursuing two extreme fuel supply options. One extreme assumes the phasing out of nuclear and its replacement with coal. The opposite assumes the phasing out of coal and its replacement with nuclear.

Exclusive use of domestic coal reserves in the all coal options would result in a significant depletion over fifty years (Table 5). Under the high growth scenario, the depletion of coal reserves would reach $37 \%$ and the annual consumption of coal would increase about 500\% over the 1987 consumption of 700 million tons. The annual generation of solid waste and gaseous emissions would tend to increase proportionally to coal consumption.

\section{TABLE 5. Coal Consumption Assuming all Future Additions to Base Load Capacity are Coal-Fired}

\begin{tabular}{|c|c|c|c|c|}
\hline $\begin{array}{c}\text { Electricity } \\
\text { Growth } \\
\text { Scenario } \\
\end{array}$ & $\begin{array}{l}\text { Cumulative } \\
\text { Consumption to } \\
2037 \text { (billions } \\
\text { of tons) } \\
\end{array}$ & $\begin{array}{l}\text { Depletion } \\
\text { of Coal } \\
\text { Reserves (a) } \\
\end{array}$ & $\begin{array}{l}\text { Annual Coal } \\
\text { Consumption in } \\
2037 \text { (billions } \\
\text { of tons) }\end{array}$ & $\begin{array}{c}\text { Increase } \\
\text { over } 1987 \\
\text { Consumption }(\%)\end{array}$ \\
\hline $\begin{array}{l}\text { High, } \\
3.5 \% / \text { year }\end{array}$ & 90 & $37 \%$ & 4.1 & 490 \\
\hline $\begin{array}{l}\text { Medium, } \\
2.5 \% / \text { year }\end{array}$ & 62 & $25 \%$ & 2.5 & 260 \\
\hline $\begin{array}{l}\text { Low, } \\
1.5 \% / \text { year }\end{array}$ & 43 & $18 \%$ & 1.4 & 100 \\
\hline
\end{tabular}

(a) Based on estimated recoverable coal reserves of 245 billion tons. Reserves are economically recoverable with current technology. 
In the all nuclear scenarios the consumption of uranium over the next fifty years would represent a significant fraction of the domestic resource (Table 6). In the high growth scenario, the consumption would be equivalent to $86 \%$ of these resources. However, since a large fraction of the uranium supply would be imported, the actual depletion of domestic resources would be much lower. The annual consumption of $\mathrm{U}_{3} \mathrm{O}_{8}$ in 2037 would increase $1650 \%$ in the high growth scenario over the 1987 consumption of 0.02 million tons.

\section{INTRODUCTION}

Previous sections of this report clearly identify the long-term need for new baseload electricity generation plants. Based on current experience, coal and nuclear technologies are unique 1) in their proven ability to provide low cost electricity using domestic fuels and 2) in their potential for significantly increased utilization. Both technologies will play a role in the future; however, the relative roles of the two technologies is subject to questions.

Aside from meeting the pure demand requirements, other factors influence decisions on the relative roles of nuclear and coal technologies. These factors include economics, reliability of the fuel supply, waste product generation and disposal, environmental and health concerns, and public acceptability.

TABLE 6. Consumption of $\mathrm{U}_{3} 0_{8}$ Assuming Nuclear Energy is used to Meet all Future Additions to Base Load Capacity

\begin{tabular}{|c|c|c|c|c|}
\hline $\begin{array}{c}\text { Growth } \\
\text { Scenario } \\
\end{array}$ & $\begin{array}{l}\text { Cumulative } \\
\text { Consumption to } \\
2037 \text { (millions } \\
\text { of tons) }\end{array}$ & $\begin{array}{l}\text { Equivalent } \\
\text { Percentage } \\
\text { of Domestic } \\
\text { Resource (a) }\end{array}$ & $\begin{array}{l}\text { Annual Consumption } \\
\text { of U308 in } 2037 \\
\text { (million tons) } \\
\end{array}$ & $\begin{array}{c}\text { Increase } \\
\text { over } 1987 \\
\text { Consumption }(\%) \\
\end{array}$ \\
\hline High & 6.1 & $86 \%$ & 0.35 & 1650 \\
\hline Medium & 3.9 & $55 \%$ & 0.21 & 950 \\
\hline Low & 2.2 & $31 \%$ & 0.11 & 450 \\
\hline
\end{tabular}

(a) Based on estimated $\mathrm{U}_{3} \mathrm{O}_{8}$ resources of 7.07 million tons recoverable at less than $\$ 500$ per pound: resources include identified, inferred, and undiscovered resources. Assumes no introduction of breeders, and no $U$ and Pu recycle. 
The purpose of this section is to assess the resource requirements and estimate the quantities of wastes generated for future supply scenarios involving various mixes of coal and nuclear plants. Projections of resource requirements and waste generation provide a perspective for formulating long range research and development plans to improve technology, mitigate adverse impacts, assure the availability of critical resources, and increase the utilization of potential by-products.

Nuclear and Coal Supply Scenarios

The three electricity growth scenarios, $1.5,2.5$, and $3.5 \% /$ year, described in the previous section, cover the prospective boundary and intermediate conditions for baseload capacity requirements. The cumulative capacity of new baseload plants required for each scenario over the next 50 years is shown in Table 7 .

We analyzed three fuel supply options, $100 \%$ coal, $50 \%$ coal $/ 50 \%$ nuclear, and $100 \%$ nuclear, for each growth scenario (Table 8). The all coal and all nuclear options have a degree of credibility. There have been calls for the phasing out of nuclear power, both here and abroad, and problems related to acid rain, the greenhouse effect, and the impacts of coal mining could conceivably severely restrict coal usage. These extreme options bracket the ranges of coal and nuclear usage expected over the long-term. An intermediate fuel supply option appears more realistic; the 50/50 option corresponds closely with recent experience in new plant additions.

TABLE 7. Cumulative Capacity (GW) in New Baseload Plants Required over Fifty Years for Alternative Growth Scenarios

\begin{tabular}{|c|c|}
\hline $\begin{array}{l}\text { Growth Rate } \\
\text { Scenario }\end{array}$ & $\begin{array}{l}\text { New Baseload } \\
\text { Capacity, GW }\end{array}$ \\
\hline High & 2067 \\
\hline Middle & 1156 \\
\hline Low & 601 \\
\hline
\end{tabular}


TABLE 8. Alternative Coal and Nuclear Supply Scenarios and Options Electricity Growth Rate Scenario Fuel Supply Options

$\begin{array}{llll}\text { High } & \text { all coal } & 50 \% \text { coal } / 50 \% \text { nuclear } & \text { all nuclear } \\ \text { Middle } & \text { all coal } & 50 \% \text { coal } / 50 \% \text { nuclear } & \text { all nuclear } \\ \text { Low } & \text { all coal } & 50 \% \text { coal } / 50 \% \text { nuclear } & \text { all nuclear }\end{array}$

Comparison with EIA Projections

A recent EIA report (DOE 87, Table 8) provided four projections of U.S. operable nuclear capacity. Our scenarios and fuel supply options encompass the EIA projections as noted below.

The EIA projections were based upon 40 year operating lifetimes whereas we assumed 40,50, and 60 year lifetimes, depending on the growth rate, for our scenarios. If we had also used 40 year lifetimes the following similarities are noted. Our all coal options were equivalent to the EIA no new nuclear orders case except that our nuclear capacity peaks at $107 \mathrm{GW}$ whereas EIA peaks at $103 \mathrm{GW}$. Our low growth scenario with the $50 \%$ nuclear option was similar to the EIA lower reference case. The EIA upper reference case was about midway between our low and middle growth scenarios each with the $50 \%$ nuclear option. The EIA optimistic case was about midway between our middle and high growth scenarios each with the $50 \%$ nuclear option.

\section{CRITICAL RESOURCE REQUIREMENTS}

The following section examines the consumption of critical resources for each of the supply scenarios. The upper boundary scenarios explore the extreme trends to see what difficulties they lead to. From a strategic point of view, this helps to identify the actions and their timing that might be undertaken to mitigate the difficulties. 
$\underline{\text { Coal }}$

The consumption of coal for each of the scenarios and fuel supply options is summarized in Table 9. The extreme case is the all-coal option in the high growth scenario; this option would consume 90 billion tons, $37 \%$ of the coal reserves, by 2037 and, if this growth rate continued, $100 \%$ would be reached in 2061. Under the middle growth $(2.5 \% /$ year) scenario, 62 billion tons of coal, cumulative, would be required through 2037 for the all-coal option; this is $25 \%$ of the United States recoverable coal reserves. And, if this rate of growth continued, $100 \%$ of the recoverable coal reserves would be consumed by 2079 .

Under the extreme case, annual coal consumption would increase to 4.1 billion tons, about six times current usage. Under the middle scenario all-coal option, annual coal consumption would reach 2.5 billion tons in

TABLE 9. Consumption of U.S. Recoverable Coal Reserves Over the Next 50 Years

\begin{tabular}{|c|c|c|c|}
\hline \multirow[b]{2}{*}{ Scenarios } & \multicolumn{3}{|c|}{ New Coal Plants } \\
\hline & $0 \%$ & $50 \%$ & $\underline{100 \%}$ \\
\hline Low & $\begin{array}{l}26^{(a)} \\
11 \%\end{array}$ & $\begin{array}{l}34 \\
14 \%\end{array}$ & $\begin{array}{l}43 \\
18 \%\end{array}$ \\
\hline Mid & $\begin{array}{l}22 \\
9 \%\end{array}$ & $\begin{array}{l}42 \\
17 \%\end{array}$ & $\begin{array}{l}62 \\
25 \%\end{array}$ \\
\hline High & $\begin{array}{r}19 \\
8 \%\end{array}$ & $\begin{array}{l}55 \\
22 \%\end{array}$ & $\begin{array}{l}90 \\
37 \%\end{array}$ \\
\hline
\end{tabular}

(a) Billion of tons consumed; lower

figure is the $\%$ of U.S. recoverable reserves of 245 billion tons (NCA 85). Reserves are economically recoverable with current technology. More abundant coal resources are recoverable at higher prices. 
2037, over three times current consumption. (a) However, this amount of increased coal combustion could exacerbate concerns over the environmental impacts of coal plants and lead to more stringent environmental control standards. More stringent standards, in turn, could result in lower fuel efficiency and the need for increased fuel consumption.

$\underline{\mathrm{U}_{3} \mathrm{O}_{8}}$

The cumulative consumption of $\mathrm{U}_{3} \mathrm{O}_{8}$ for each of the scenarios and fuel supply options is summarized in Table 10; in the extreme case (high growthall nuclear) the $\mathrm{U}_{3} \mathrm{O}_{8}$ consumption would reach 6.1 million tons, which is equivalent to $86 \%$ of the U.S. resources. Under the all-nuclear option for

IABLE 10. Consumption of $\mathrm{U}_{3} \mathrm{O}_{8}$ Over the Next 50 Years

\begin{tabular}{|c|c|c|c|}
\hline \multirow[b]{2}{*}{$\underline{\text { Scenario }}$} & \multicolumn{3}{|c|}{ New Nuclear Plants } \\
\hline & $0 \%$ & $50 \%$ & $100 \%$ \\
\hline Low & $\begin{array}{l}0.9^{(a)} \\
13 \%\end{array}$ & $\begin{array}{l}1.5 \\
22 \%\end{array}$ & $\begin{array}{l}2.2 \\
31 \%\end{array}$ \\
\hline Middle & $\begin{array}{l}0.8 \\
12 \%\end{array}$ & $\begin{array}{l}2.3 \\
33 \%\end{array}$ & $\begin{array}{l}3.9 \\
55 \%\end{array}$ \\
\hline High & $\begin{array}{r}0.6 \\
9 \%\end{array}$ & $\begin{array}{l}3.4 \\
48 \%\end{array}$ & $\begin{array}{l}6.1 \\
86 \%\end{array}$ \\
\hline
\end{tabular}

(a) Million of tons consumed; lower figure is the equivalent $\%$ of the mean estimate for domestic $\mathrm{U}_{3} \mathrm{O}_{8}$ resources of $7.07 \mathrm{million}$ tons recoverable at less than $\$ 500$ per pound ( $\mathrm{Pi} 81, \mathrm{p}$. $\mathrm{i} i$ ).

(a) Although coal could be phased-in to replace existing nuclear capacity over a number of years, an immediate shutdown in nuclear capacity and replacement with coal could cause severe economic disruptions in at least five of the nine NERC regions (Appendix $\mathrm{H}$ ). The reserve margins in these five regions would fall below $20 \%$. Nuclear generated between 20 and $44 \%$ of the electricity in these regions in 1988. 
the middle scenario, 3.9 million tons, cumulative, of $\mathrm{U}_{3} \mathrm{O}_{8}$ would be required through 2037; this is $55 \%$ of the total United States $\mathrm{U}_{3} \mathrm{O}_{8}$ resource recoverable at less than $\$ 500$ per pound.

For perspective, 3.9 million tons of $\mathrm{U}_{3} \mathrm{O}_{8}$ could be recovered at production costs under $\$ 100$ per pound $\mathrm{U}_{3} \mathrm{O}_{8}$ and 6.1 million tons could be recovered at less than $\$ 150$ per pound ( $\mathrm{Pi} 81, \mathrm{P} .3 .4$ ). However, since imports should continue to provide a substantial fraction of the $\mathrm{U}_{3} 08$ supply, the depletion of domestic resources should be much lower. The actual price increases, therefore, should be much lower. In addition, an increase in demand of this magnitude should provide sufficient incentive for $\mathrm{Pu}$ and $\mathrm{U}$ recycle and the introduction of breeder or advanced converter reactors well before the end of the period in order to avoid significant resource depletion, over-dependence on imports, and much higher uranium prices.

Under the middle scenario all-nuclear option, annual $\mathrm{U}_{3} 08$ requirements would increase to 208,000 tons in 2037, about ten times current consumption. Consequently, the number of fuel assemblies required would increase about ten-fold to 45,000. Similarly, U308 consumption would reach 351 thousand tons in 2037 for the all nuclear, high growth option; about 17 times current consumption.

Mine development is the critical path step in the expansion of uranium production. The current capacity of United States uranium mines is uncertain. Many mines have shut down because of the depressed state of the industry. But if all of the $\mathrm{U}_{3} \mathrm{O}_{8}$ requirements in the all-nuclear option of the middle scenario were met by domestic mines, United States uranium production would reach new peaks about 1997 (U308 production peaked at 22,000 tons in 1980) (00E 86c,p.40). The amount of uranium imports, which is a major factor in the domestic supply, will determine the need for domestic mine development. The long lead times for power plant construction should provide sufficient time for obtaining $\mathrm{U}_{3} \mathrm{O}_{8}$ supplies, either foreign or domestic, to meet the growing needs. Uranium Enrichment

Existing United States enrichment capacity (currently 27 million separative work units; DOE 85e, p. 40) appears to be adequate for at least 
20 years. Under the half-nuclear option for the middle growth scenario, the separative work capacity would be reached about 2015 (Table 11). By this time, new enrichment capacity or plutonium recycle would be required to maintain the reference fuel exposure, assuming no imports of enrichment services. The year in which existing enrichment capacity is reached for each of the scenarios is shown in Table 11.

Spent Fuel Disposal

The federal government, through the nuclear waste policy act, is planning to provide waste repositories for spent nuclear fuel. The first repository is planned to begin operation about 2003. Assuming a once-through cycle and spent fuel cooled 10 years: 1) the middle growth scenario with the $50 \%$ nuclear option would require a second repository $(70,000$ MTU capacity) in 2021 and a third repository would be needed in 2033; 2) the middle growth all nuclear scenario would require the second repository in 2017 and the third repository in 2028; 3) the high growth scenario with the all nuclear option would require the second repository in 2015 and the third in 2023. The all coal options for all scenarios would require only one repository.

TABLE 11. Year in which Existing Enrichment Capacity is Reached under Alternate Scenarios

\begin{tabular}{|c|c|c|}
\hline Electricity Growth Rate & $\begin{array}{l}\text { Load } \\
50\end{array}$ & $\begin{array}{l}\text { ants } \\
100\end{array}$ \\
\hline High, $3.5 \% /$ year & 2010 & 2000 \\
\hline Medium, $2.5 \% /$ year & 2015 & 2010 \\
\hline Low, $1.5 \% /$ year & 2030 & 2020 \\
\hline
\end{tabular}




\section{Reprocessing}

Reprocessing of spent nuclear fuels provides a potential to conserve enrichment capacity, uranium resources, and waste generation. Reprocessing is capital intensive and requires a lengthy lead time. Although reprocessing is currently not included in fuel cycle planning, the lack of capacity could constrain nuclear power growth under high growth scenarios in which $\mathrm{U}_{3} \mathrm{O}_{8}$ depletion becomes significant. Reprocessing is required for breeder reactor deployment.

\section{Potential Growth in Annual Fuel and Waste Disposal Requirements}

In 1987, coal generated 1453 billion kWh and the coal consumption was 705 million tons (NERC 87). For illustration, the coal consumption and waste generation in 1987 is compared with the projected consumption and waste generation in 2037 for the all coal option for the middle growth scenario (Table 12). The consequences of pursuing the all coal option would lead to a 3.5 fold increase in annual coal consumption and waste generation.

In 1987, nuclear generated 452 billion KWh; 20,000 tons of $U_{308}$ were consumed in fabricating $2000 \mathrm{MT}$ (U) of enriched $\mathrm{U}_{2}$ fuel assemblies to produce this electricity. Pursuing the all nuclear option in the middle growth scenario would lead to a ten-fold increase in the nuclear fuel cycle requirements and nuclear waste generation (Table 13).

Comparing Tables 12 and 13 also illustrates the orders of magnitude greater fuel consumption and waste generation associated with coal compared to nuclear fuel. The fuel consumption and waste generation for selected intermediate years for all scenarios and fuel options are shown in Appendix F. 
TABLE 12. Estimated Fuel Requirements and Waste Generation for Coal-Generated Electricity in 1987 and 2037 (a)

\begin{tabular}{|c|c|c|}
\hline & 1987 & $2037(a)$ \\
\hline $\begin{array}{l}\text { Mining } \\
\text { (tons mined) }\end{array}$ & $840,000,000$ & $2,945,000,000$ \\
\hline $\begin{array}{l}\text { Mine and Mill waste } \\
\text { (cubic yards) }\end{array}$ & $110,000,000$ & $391,000,000$ \\
\hline Coal Shipments (tons) & $705,000,000$ & $2,474,000,000$ \\
\hline $\begin{array}{l}\text { Electricity Generation } \\
(\text { TWh })(b)\end{array}$ & 1,453 & 6,109 \\
\hline $\begin{array}{l}\text { Non-Radioactive waste } \\
\text { (cubic yards) }\end{array}$ & $115,000,000$ & $403,000,000$ \\
\hline \multicolumn{3}{|l|}{$\begin{array}{l}\text { Gaseous Emissions } \\
\text { (thousands of tons) }\end{array}$} \\
\hline $\mathrm{SO}_{2}$ & 2,800 & 9,900 \\
\hline $\mathrm{NO}_{\mathrm{x}}{ }^{(\mathrm{c})}$ & 3,900 & 14,000 \\
\hline $\mathrm{CO}_{2}$ & $2,300,000$ & $7,900,000$ \\
\hline
\end{tabular}

(a) For middle growth $(2.5 \%)$ scenario-all coal option.

(b) TWh = one billion kWh.

(c) Based on current emission limits. 
TABLE 13. Estimated Fuel Cycle Requirements and Waste Generation for Nuclear-Generated Electricity in 1987 and 2037

\begin{tabular}{|c|c|c|}
\hline & 1987 & $2037(a)$ \\
\hline $\begin{array}{l}\text { Mining } \\
\text { (tons mined) }\end{array}$ & $16,000,000$ & $165,000,000$ \\
\hline $\begin{array}{l}\text { Mine and Mill Waste } \\
\text { (cubic yards) }\end{array}$ & $13,000,000$ & $137,000,000$ \\
\hline $\mathrm{U}_{3} \mathrm{O}_{8}$ Shipments (tons) & 20,000 & 208,000 \\
\hline $\begin{array}{l}\text { Uranium Enrichment } \\
\text { (millions of separa- } \\
\text { tive work units) }\end{array}$ & 9 & 97 \\
\hline $\begin{array}{l}\text { Fuel Fabrication } \\
\text { (Equivalent number of } \\
\text { PWR fuel assemblies) }\end{array}$ & 4,300 & 45,000 \\
\hline $\begin{array}{l}\text { Electricity Generation } \\
(\text { TWh })(b)\end{array}$ & 452 & 5,943 \\
\hline $\begin{array}{l}\text { Non-Radioactive waste } \\
\text { (cubic yards) }\end{array}$ & 4,400 & 46,000 \\
\hline $\begin{array}{l}\text { Low Level Radioactive } \\
\text { waste (cubic yards) }\end{array}$ & 77,000 & 832,000 \\
\hline $\begin{array}{l}\text { High Level Radioactive } \\
\text { Waste (cubic yards) }\end{array}$ & 1,300 & 13,000 \\
\hline Gaseous Emissions & 0 & \\
\hline
\end{tabular}

(a) For middle growth (2.5\%) scenario-all nuclear option.

(b) TWh = one billion kwh. 



\section{FOREIGN NUCLEAR TRENDS}

World-wide trends are toward increasing use of nuclear power in most of the nations that now have nuclear capacity and towards the introduction of nuclear capacity into some developing nations. The incentives are reduced dependence on imported energy supplies, cost competitiveness, and reduced environmental pollution. Increasing foreign usage should impact the U.S. situation in several ways. First, increased resource depletion could lead to increased fuel costs and greater incentives for fuel recycle and breeding. Second, greater activity and competition should spur technological advances. Third, increased operating experience should lead to improved designs and operating procedures. Fourth, more widespread usage should provide more opportunities for creative solutions to political and institutional issues. And fifth, an active global market should provide competitive state-ofthe-art production capabilities and supporting infrastructure for reactor construction and for all parts of the fuel cycle.

Most nations plan to build light water reactors, particularly the large PWR. The trend is toward larger units of a standardized design: for instance, in France new plants will be 1400 MW PWRs with plans for 2000 MW later. The USSR is building 1000 MW PWRs and designing an 1800 MW PWR. Great Britain is planning to construct several 1150 MW PWRs.

Foreign and U.S. nuclear policies differ notably in their plans for reprocessing spent LWR fuel and recycling the uranium and plutonium into LWRs. The foreign nations with the largest nuclear capacities plan to reprocess and recycle. Japan and France are most advanced in their reprocessing and recycling programs. After Pu fuel irradiation tests now underway in Japan are completed, up to 23 Japanese reactors will burn mixed oxide (MOX) fuel reloads by late 1990's. Japan is also developing Puburning advanced thermal reactors. France plans to load mixed oxide fuel into sixteen 900 MWe PWRs by 1995 . The net savings in France from recycle fuel is estimated at $\$ 98$ million per year by 1995 and the cumlative savings are put at $\$ 770$ million in constant 1987 dollars: $\$ 570$ million in $U_{30}$ purchases and $\$ 200$ million in separate work (Nuclear Fuel, November 16 , 1987). 
Foreign commercial reprocessing capacity is 2738 MI(HM) per year; new capacity under construction is 6150 MT(HM) per year (Table 14).

France, West Germany, Japan, and Belgium are known to have operable MoX fuel fabrication facilities (NEI89); the total current capacity for MOX fuel fabrication is estimated to be over $100 \mathrm{MT} /$ year. In Belgium the Dessel plant has a MOX capacity of $35 \mathrm{MT} /$ year. Existing MOX plants in France and West Germany each have capacities of 25 MT/year. The new Melox plant in France will have 150 MT/year MOX capacity and should be commissioned in 1992. The UK participates with France and Belgium in MOX fuel R\&D. A new UK MOX fuel plant may be brought into operation in late 1990's.

Many European countries have joined together with Japan, under cooperative agreement, to develop the breeder reactor. However, no large scale deployment is planned during the next 20 years.

TABLE 14. Foreign Reprocessing Capacity (MT/year)

\begin{tabular}{|c|c|c|c|}
\hline & Operable & Under Construction & Total \\
\hline France & 800 & 1600 & 2400 \\
\hline West Germany & 40 & 350 & 390 \\
\hline India & 280 & 1000 & 1280 \\
\hline Japan & 210 & 800 & 1010 \\
\hline UK & 1008 & 1200 & 2208 \\
\hline USSR & 400 & 1200 & 1600 \\
\hline Total & $2738^{\star}$ & 6150 & $8888^{*}$ \\
\hline
\end{tabular}

* Some existing capacity may be shutdown or decommissioned when new capacity is brought online.

Sources: Nuclear Engineering International, World Nuclear Industry Handbook, 1989, Sutton Surry, UK and CR Cooley, OCAWM-DOE, Foreign Travel Report: IAEA International Waste Management Advisory Committee meeting, Vienna, Austria, April 10-14, 1989; presentation and discussion by AS Nikiforov, USSR. 
Many of the 31 nations that now have nuclear power plants in operation or under construction plan to increase their nuclear capacity. New nuclear plants are now under construction in 22 nations.

World nuclear capacity increased 4\% in 1988 to $310 \mathrm{GW}$ with 428 reactors in operation. Twelve new reactors, with a combined capacity of $12 \mathrm{GW}$, were completed in France, Germany (FRG), Korea, Spain, UK, USSR, and the U.S. (Nuclear News, April 1989, p. 80). Nuclear power was being produced in 26 countries at the end of 1988. An additional 109 nuclear plants, representing $88 \mathrm{GW}$, were under construction. Completion of these units will increase nuclear capacity to $398 \mathrm{GW}$ or about $25 \%$ of the world's total generating capacity.

Nuclear energy provides $20 \%$ of the world's electricity generation and a much larger fraction of the electricity supply in several nations. Nearly all of the nations with substantial nuclear capacity strongly support nuclear power since continued and increased reliance on nuclear energy is vital to their economic competitiveness, environmental objectives, and energy security (Nucleonics week 12/10/87). The International Chamber of Commerce (ICC) in a policy statement said that nuclear energy "should be retained as a major source of energy for electricity generation" and that nuclear energy has "proved its competitiveness" and "its environmental advantages" during normal operation.

Opposition to nuclear power is strong in several countries. Moratoria, phase-outs, and construction bans are in-place or planned in west Germany, Sweden, Italy, Spain, and Yugoslavia, all of which now have operating nuclear plants. Several nations, e.g., Austria and Ireland which do not have nuclear plants, have banned nuclear construction.

Most of the national policies for radioactive waste disposal assume interim storage for periods of 10 to 60 years followed by geologic disposal of either vitrified high level waste or spent fuel assemblies.

The ordering rate for new nuclear capacity has slowed recently in response to slower growth rates in electricity demand and opposition to nuclear power, and should continue slow over the next decade. 



\section{DISCUSSION AND CONCLUSIONS}

Growth in electricity demand has historically been closely linked to growth in GNP. For the first three-quarters of the twentieth century, a period of declining real electricity costs, the electricity demand grew faster than the growth in GNP. Since the 1973 oil embargo, real electricity costs have increased and the growth rate of electricity consumption has been approximately the same as that of the GNP.

During the next decade electricity demand is likely to increase at a slightly faster rate than real GNP growth because the real price of electricity should decline over this period. There are several reasons to expect reductions in the real price of electricity:

- Energy supplies should remain abundant during most of the decade because of current over-capacity.

- Completion of new power plants will slow markedly, resulting in fewer additions to utility rate bases.

- Lower interest rates are permitting refinancing of existing utility debt, thus lowering fixed charges.

- Current surplus capacity will be eliminated through growth, thus increasing the overall system capacity factor.

- The potential exists for increased competition between electricity suppliers in the future.

Over the longer term, the potential exists for continued reductions in the real price of electricity through technology improvements, continued low interest rates, and construction cost decreases resulting from the standardization of plant designs, shorter construction periods, and increased regulatory stability. If the real price of electricity declines, electricity demand will probably increase at a rate faster than that of the real GNP. 
On the other hand, several factors could result in increasing prices of electricity and slower growth rates over the long-term. Some possibilities are:

- Introduction of more stringent limits on emissions resulting from coal combustion could significantly increase the costs of electricity generated by coal plants.

- Over-reliance on a single technology could decrease the competitive environment that now exists between technologies (e.g., coal and nuclear).

- Utilities could choose to use higher cost technologies for new capacity because of shorter lead times and reduced financial risks (e.g., gas turbines).

- Under-estimating growth in demand could cause increased utilization of higher cost, short lead time technologies.

On balance we believe that real electricity prices are more likely to either fall or hold steady than rise. Therefore, we expect electricity demand to grow or remain constant relative to GNP. Over the long term GNP should continue to grow in the $2-3 \%$ range in response to productivity improvements and population growth. Even if population stabilizes, the desire for higher standards of living should cause continued growth in GNP. In fact, increased electricity usage is usually involved in productivity and materials improvements.

Most forecasts of electricity demand project an average growth rate between 1.5 and $3.5 \%$ per year over the next three decades. At these growth rates new plants will be required in the year 2000 at a "best estimate" annual rate of about $30 \mathrm{GW}$ per year. This is comparable to the $33 \mathrm{GW}$ per year that were added during the 1973-1977 time period and is significantly more than the planned addition of about $7 \mathrm{GW}$ per year during the 1991-1995 time frame. It is important to recognize that once the current surplus capacity no longer exists, 10-25 GW per year will be required to meet growth needs alone (excluding the need for replacement of obsolete capacity). 
The need to replace obsolete capacity will have a significant impact on the need for building new plants. For instance, if the average age of plants at retirement is 60 years, only $10 \mathrm{GW}$ of obsolete capacity will have to be replaced during the 1995-2005 time frame; whereas $200 \mathrm{GW}$ of obsolete capacity must be replaced for average plant lifetimes of 40 years. Thus, the average annual requirement for replacenent of obsolete capacity during that time frame will range from $1 \mathrm{GW}$ to $20 \mathrm{GW}$. The wide range in potential requirements for replacing old plants demonstrates the enormous incentives that might be realized if the lifetimes of these plants can be extended from 40 to 60 years. This should give planners some sense of urgency in the need to pursue plant life extension efforts.

Based on current experience, only coal and nuclear technologies have the abundant indigenous resources and demonstrated capability to economically meet new growth requirements. In 1984, coal and nuclear plants generated $68 \%$ of the electricity; this increased to $74 \%$ in 1987 and is projected to continue at about $74 \%$ through 1997. Planned additional new baseload capacity through 1997 is about equally divided between coal and nuclear plants. For a number of decades beyond that time frame, sufficient indigenous resources exist such that either coal or nuclear technologies alone could meet growth requirements. However, because of concerns over each energy source and because of benefits associated with utilizing both technologies, an over-dependence on either should continue to be avoided. Significant concerns and benefits are summarized below.

- The continuing fuel requirements and waste generation associated with coal plants are orders of magnitude greater than for nuclear plants. Nothing can change this. There are already concerns over the risks and environmental consequences of the existing level of coal usage. These concerns could limit future increases in coal usage. Research is needed to determine acceptable emission limits relevant to acid rain and possibly, in the future, to $\mathrm{CO}_{2}$ emissions. New technologies will be needed to meet future emission limits and handle the solid waste residues. 
- Many concerns over the safety and economic viability of nuclear power have increased public opposition and eroded utility support. These concerns, unless resolved, could limit the future rate of growth of nuclear energy. Measures are needed to reduce financial risk to utilities, simplify licensing, reduce reactor construction times and costs, resolve nuclear waste disposal concerns, and alleviate public concerns about nuclear safety.

- Reliance on a single technology would lead to a less competitive environment, probably resulting in higher electricity prices. For example, a measure of the economic success of a particular nuclear power plant design is its ability to compete economically with coal plants.

- Although we have large domestic coal reserves, $25 \%$ or more would be consumed in the next 50 years if we were to rely exclusively on coal for new baseload capacity. It is probably not in the long-term national interest to deplete this resource at that rate. Much of the coal reserves are in the West on federal lands. These lands would have to be opened to leasing and mine development. Large scale importation of coal is not a viable option. However, utilization of large amounts of imported uranium is feasible because compared to coal, the transportation requirements are orders of magnitude lower, stockpiling costs are lower, and the cost per unit of electricity production is substantially lower. Additionally, nuclear power holds the promise for extending domestic uranium supplies for many centuries through the use of breeder reactors.

- The drop-off in domestic orders threatens the viability of the domestic nuclear industry, but increasing foreign use of nuclear power should preserve the nuclear option for the U.S. Adoption of foreign technology could impact the U.S. in several ways, such as, by limiting the reactor options to large or larger PWRs of standardized designs. Increasing foreign usage should increase resource depletion and potentially lead to increased fuel costs. 
A growing foreign market could provide foreign suppliers with a competitive advantage in having modern production facilities and supporting infrastructure.

All of the foregoing data point to the general conclusion that new base load plants must and will be constructed. The future demand is immense, easily large enough to support development of completely new generating technologies. The future demand is also too large to be filled solely by a new technology in less than 30 years, given typical technology penetration rates. Thus, existing technologies must continue to play an important role in the near to mid term.

The United States and the world should develop and apply the best technology to make maximum use of limited resources to meet future energy demands, notably electricity. Technology improvements and waste management practices obviously must be pursued and implemented to mitigate environmental impacts from electricity generation. Improvements in safety over the entire fuel cycle are always motivating factors in technology development and application. Additions to generating capacity and improvements in the quality of generating technology are not options but imperatives. 


\section{REFERENCES}

BL 87 Bloomster, C. H., and E. T. Merril1. 1987. Long-Term Need for New Generating Capacity. PNL-6193, Pacific Northwest Laboratory, Richland, Washington.

DOE 83 Energy Projections to the Year 2010. 1983. DOE/PE-0029/2. NTIS-PR-360, National Technical Information Service, U.S. Department of Commerce, Springfield, Virginia.

DOE 84 U.S. Department of Energy (DOE). 1984. "The Role of Nuclear Power," DOE/NE-0054. Washington, D.C.

DOE 85 Energy Information Administration. 1985. Commercial Nuclear Power: Prospects for the United States and the World. DOE/EIA-0438(85), U.S. Government Printing office, Washington, D.C.

DOE 85a Energy Information Administration, Office of Coal, Nuclear, Electric, and Alternate Fuels. 1985. Annual Outlook for U.S. Electric Power 1985. DOE/EIA-0474(85), U.S. Government Printing Office, Washington, D.C.

DOE 85b Cornett, C. M. 1984. Analys is of Growth in Electricity Demand. 1980-1984. DOE/EIA-0476. Superintendent of Documents, U.S. Government Printing Office, Washington, D.C.

DOE 85c Inventory of Power Plants in the United States 1984. 1984. DOE/EIA-0095(84), Superintendant of Documents, U.S. Government Printing Office, Washington, D.C.

DOE 85d Energy Information Administration. 1985. Electric Power Annual 1984. DOE/EIA-0348(84), U.S. Government Printing Office, Washington, D.C.

DOE 85e Energy Information Administration. 1985. World Nuclear Fuel Cycle Requirements 1985. DOE/EIA-0436(85), U.S. Government Printing office, Washington, D.C.

DOE 86a Energy Information Administrations. 1986. Domestic Uranium Mining and Milling Industry: 1985 Viability Assessment. DOE/EIA-0477(85), U.S. Government Printing office, Washington, D.C. , November 13, 1986.

DOE 86b Energy Information Administrations. 1986. Domestic Uranium Mining and Milling Industry: 1986 Viability Assessment. DOE/EIA-0477(85), U.5. Government Printing Office, Washington, D.C., November 13, 1986. 
DOE 86c Energy Information Administration. October 9, 1987. Uranium Industry Annual 1986. DOE/EIA-0478(86), U.S. Government Printing office, Washington, D.C.

DOE 87 Energy Information Administration, Commercial Nuclear Power 1987: Prospects for the United States and the World, DOE/EIA-0438(87) (Washington, DC, July 1987), Table 8.

DOE 87a Energy Information Administration. October 1987. Uranium Industry Annual 1986, D0E/EIA-0478(86), U.S. Government Printing office, Washington, D.C.

ED 86 "Virginia Power Orders New Gas-Fired Plant." 1986. The Energy Daily. Vol. 14, No. 162.

EPRI 78 Costs and Benefits of Over/Under Capacity in Electric Power System Planning. 1978. EPRI EA-927, Decision Focus, Incorporated, Palo Alto, California.

EPRI 84 Kurgan, G. J., J. M. Balestrino, and J. R. Daley. 1984. Coal Combustion By-products Utilization Manual - Volume 1. EPRI CS-3122, Electric Power Research Institute, Palo Alto, California.

EPRI 85 Electric Power Research Institute (EPRI). 1985. NERC Summary Load Forecasts: A Retrospective Appraisal and Technical Analysis.

EPRI 86 Douglas, J. 1986. "The Value of Reliability." In the EPRI Journal. Vol. 11, Number 2.

EW 85 "36th Annual Electric Utility Industry Forecast." Electrical World, September 1985.

EW 88 "Annual Industry Forecast." Electrical World, October 1988, pp. $67-72$.

Fi 84 Finley, N. C., and N. H. Clark. 1984. Review and Evaluation of Literature on Coal and Nuclear Fuel Cycle Risk Comparisons. DE840D15124, Sandia National Laboratories, Albuquerque, New Mexico.

Hy 85 Hyman, L. S. 1985. America's Electric Utilities: Past, Present, and Future. No. ISBN 0-910325-08-1. Public Utilities Reports, Inc., Arlington, Virginia.

NCA 85 National Coal Association. 1985-86 Facts About Coal. Washington, D.C.

NERC 85 North American Electric Reliability Council. 1985. Electric Power Supply \& Demand for 1985-1994, October 1985. 
NERC 86 North American Electric Reliability Council. 1986. Electricity Supply and Demand for 1986-1995, October 1986.

NERC 87 North American Electric Reliability Council. 1987. Electricity Supply and Demand for 1987-1996, October 1987.

NERC 88 North American Electric Reliability Council. 1988. Electricity Supply and Demand for 1988-1997, October 1988.

NRC 86 Cormittee on Electricity in Economic growth, Energy Engineering Board, Commission on Enginerring and Technical Systems, National Research Council. 1986. Electricity in Economic Growth. National Academy Press, Washington, D.C.

OTA 84 U.S. Congress, Office of Technology Assessment. 1984. Nuclear Power in an Age of Uncertainty. E OTA-E-216, Washington, D.C.

Pi 85 Piepel, G. F., L. W. Long, R. A. McLaren, and C. E. Ford. 1981. Probabilistic Estimates of U.S. Uranium Supply. PNL-3595, Pacific Northwest Laboratory, Richland, Washington.

Se 85 Searl, M. F. 1985. Electricity and Economic Growth in the U.S. 1947-2000. Paper presented at the ANS Annual Meeting, June 11, 1985, Boston, Maine.

Senate 85 Committee on Energy and Natural Resources. 1985. Hearings before the Committee on Energy and Natural Resources United States Senate Ninety-Ninth Congress. No. 53-859 0, U.S. Government Printing office, Washington, D.C.

Wi 75 Williams, Roy E. 1975. Waste Production and Disposal in Mining, Milling, and Metallurgical Industries. ISBM 0-87931-035-3, Milton Freeman Publications, Inc. 



\section{GLOSSARY}

Baseload Capacity: The generating equipment normally operated to serve loads on an around-the-clock basis.

Boiling-Water Reactor (BWR): A light-water reactor in which water, used as both coolant and moderator, is allowed to boil in the reactor core. The resulting steam can be used directly to drive a turbine.

Capability: The maximum generating capacity available at a given instant of time, usually the sumner peak. The capability is often less than the rated capacity because of deratings caused by high cooling water temperatures in the heat rejection system and other factors.

Capacity: The load for which a generating unit is rated, either by the user or by the manufacturer.

Capacity Factor: The ratio of the electricity produced by a generating unit, for the period of time considered, to the energy that could have been produced at continuous full-power operation during the same period.

EIA: Energy Information Administration, part of DOE.

Elasticities of Demand: The proportionate change in the quantity of energy demanded resulting from a proportionate change in price. The income elasticity of demand is defined similarly for changes in income. Elasticities are calculated as the ratio of the respective proportionate changes.

Generation (Electricity): The process of producing electric energy from other forms of energy; also, the amount of electric energy produced, expressed in watthours (Wh).

Gross Generation: The total amount of electric energy produced by generating units in a generating station or stations, measured at the generator terminals.

Net Generation: Gross generation less the electric energy consumed at the generating station for station use. (Energy required for pumping at pumped-storage plants is regarded as plant use and is subtracted from gross generation or from hydroelectric generation.)

Gigawatt (GW): One billion watts.

Gross National Product (GNP): A measure of the final output of goods and services by citizens of a country, whether living at home or in foreign countries. GNP comprises GDP and factor incomes from abroad accruing to residents, less the income earned in the domestic economy accruing to citizens of other countries. 
HTGR: High Temperature Gas-cooled Reactor, a graphite-moderator heliumcooled reactor operating at a high temperature and high thermal to electric conversion efficiency.

Intermediate or Load-following Capacity: Generating capacity that operates on an intermediate (between the baseload and peaking capacities) basis.

Kilowatt $(\mathrm{kw})$ : One thousand watts.

Kilowatthour (kWh): One thousand watthours.

Light Water: Ordinary water $\left(\mathrm{H}_{2} \mathrm{O}\right)$, as distinguished form heavy water or deuterium oxide $\left(\mathrm{D}_{2} \mathrm{O}\right)$.

Light-water Reactor (LWR): A nuclear reactor that uses water as the primary coolant and moderator, with slightly enriched uranium as fuel. There are two types of commercial light-water reactor--the boiling-water reactor $(B W R)$ and the pressurized-water reactor (PWR).

Load Following: Regulation of the power output of electric generators within a prescribed area in response to changes in system frequency, tieline loading, or the relation of these to each other, so as to maintain the scheduled system frequency and/or the established interchange with other areas within predetermined limits.

Megawatt (MW): One million watts.

Megawatthour (MWh): One million watthours.

Nameplate Capacity: The nominal electrical output of a generator, as specified by the manufacturer.

NERC (North American Electric Reliability Council): An organization of the electric utility industry founded to promote the reliability of bulk power supply in the electric utility systems of North America.

Net Energy for Load: The annual electrical energy needed to serve the utilities customers. It includes transmission losses. It represents the net energy generated internally plus energy purchases (imports) less energy sales (exports).

Nuclear Power Plant: A single-or multi-unit facility in which heat produced in a reactor(s) by the fissioning of nuclear fuel is used to drive a steam turbine $(\mathrm{s})$. 
Nuclear Reactor: An apparatus in which the nuclear fission chain can be initiated, maintained, and controlled so that energy is released at a specific rate. The reactor apparatus includes fissionable material (fuel) such as uranium or plutonium; fertile material; moderating material (unless it is a fast reactor); a heavy-walled pressure vessel; shielding to protect personnel; provision for heat removal; and control elements and instrumentation.

Peaking Capacity: Generating capacity operated for short periods of time to meet peak demands on a daily or seasonal basis.

Peak Demand: In this report peak demand usually refers to the highest annual national demand. This is the sum of the peak annual demands in each region. The regional peaks are non-coincident. There are daily peak demands and seasonal peak demands for which peaking capacity is required.

Planned Resources: The total generating capacity, existing, under construction, or planned, plus scheduled capacity purchases less capacity sales.

Plutonium $(\mathrm{Pu})$ : A heavy, fissionable, radioactive, metallic element (atomic number 94). Plutonium occurs in nature in trace amounts. It can also be produced as a byproduct of the fission reaction in a uranium-field nuclear reactor and can be recovered for future use.

Pressurized-Water Reactor (PWR): A nuclear reactor in which heat is transferred from the core to a heat exchanger via water kept under high pressure, so that high temperatures can be maintained in the primary system without boiling the water. Steam is generated in a secondary circuit.

Reliability: The degree to which the performance of the elements of a bulk power electric system results in power being delivered to consumers within accepted standards and in the amount desired.

Reserve Margin: The installed capacity above the peak demand, defined as, (capacity less peak demand)/peak demand, and expressed in percent.

Separative Work Unit (SWU): A measure of the work or energy expended to separate a quantity of uranium of a given assay into two components, one having a higher percentage of uranium-235 and one having a lower percentage.

Summer Capability: The gross electrical output measured at the output terminals of the turbine generator(s) at the summer peak.

Terawatthour (TWh): One trillion $\left(10^{12}\right)$ wathours. 
Uranium $(U)$ : A heavy, naturally radioactive, metallic element (atomic number 92). Its two principally occurring isotopes are uranium-235 and uranium-238. Uranium-235 is indispensable to the nuclear industry, because it is the only isotope existing in nature to any appreciable extent that is fissionable by thermal neutrons. Uranium-238 is also important, because it absorbs neutrons to produce a radioactive isotope that subsequently decays to plutonium-239, an isotope that also is fissionable by thermal neutrons. 
APPENDIX A

PROJECTIONS OF ELECTRICITY DEMAND 


\section{APPENDIX A}

\section{PROJECTIONS OF ELECTRICITY DEMAND}

This appendix lists the projections of electricity demand made over the past several years by numerous forecasters. The base (reference) year and the forecasted year are listed for each forecast. The average annual growth rate is the value of interest in comparing the forecasts covering different base years and time frames. 
TABLEA.1. Projections of Electricity Demand

\begin{tabular}{|c|c|c|c|c|c|c|}
\hline Source & $\begin{array}{l}\text { Base } \\
\text { Year }\end{array}$ & $\begin{array}{l}\text { Base value, }{ }^{(a)} \\
\text { billions kwh } \\
\end{array}$ & $\begin{array}{l}\text { Average } \\
\text { Annua } 1 \\
\text { Growth } \\
\text { Rate, }\end{array}$ & $\begin{array}{l}\text { Fore- } \\
\text { Cast } \\
\text { Year }\end{array}$ & $\begin{array}{l}\text { Forecast } \\
\text { Value, } \\
\text { billions kwh }\end{array}$ & Reference \\
\hline DOE-EIA (High) & 1985 & 2470 & 3.8 & 1995 & 3586 & 1 \\
\hline DOE-EIA (Low) & 1985 & 2470 & 3.7 & 1995 & 3552 & 2 \\
\hline DOE-EIA (Base) & 1985 & 2470 & 3.2 & 1995 & 3384 & 3 \\
\hline Siegel/Sillin & 1983 & 2310 & 4.5 & 2000 & 4881 & 4 \\
\hline DOE-EIA & 1983 & 2310 & 3.3 & 1995 & 3410 & 5 \\
\hline $\begin{array}{l}\text { Data } \\
\text { Resources, } \\
\text { Inc. }\end{array}$ & 1983 & 2310 & 3.1 & 2000 & 3881 & 6 \\
\hline DOE & 1982 & 2241 & 2.8 & 2000 & 3683 & 7 \\
\hline $\begin{array}{l}\text { Electrical } \\
\text { World }\end{array}$ & 1983 & 2310 & 2.8 & 2000 & 3693 & 8 \\
\hline $\begin{array}{l}\text { Dept. of } \\
\text { Commerce }\end{array}$ & 1983 & 2310 & 2.5 & 2000 & 3514 & 9 \\
\hline $\begin{array}{l}\text { Ntl. Coal } \\
\text { Assoc. }\end{array}$ & 1982 & 2241 & 2.3 & 1995 & 3011 & 10 \\
\hline Wharton & 1983 & 2310 & 3.0 & 1994 & 3197 & 11 \\
\hline GRI & 1983 & 2310 & 2.4 & 2000 & 3457 & 12 \\
\hline Conoco, Inc. & 1982 & 2241 & 2.1 & 2000 & 3257 & 13 \\
\hline $\begin{array}{l}\text { R.W. Sant, } \\
\text { et al. }\end{array}$ & 1981 & 2295 & 1.5 & 2000 & 3045 & 14 \\
\hline $\begin{array}{l}\text { National } \\
\text { Audubon } \\
\text { Society }\end{array}$ & 1980 & 2286 & -0.8 & 2000 & 1946 & 15 \\
\hline NERC & 1983 & 2310 & 2.7 & 1993 & 3015 & 16 \\
\hline Chemical Bank & 1982 & 2241 & 2.9 & 2000 & 3749 & 17 \\
\hline NERC & 1984 & 2413 & 2.35 & 1994 & 3044 & 18 \\
\hline Wharton & 1984 & 2413 & 2.8 & 1994 & 3180 & 19 \\
\hline
\end{tabular}

(a) A11 values converted to net generation basis. Base values are as reported by EIA. Net generation is approximately $9 \%$ greater than end use consumption. 
IABLE A.1. (contd)

\begin{tabular}{|c|c|c|c|c|c|c|}
\hline Source & $\begin{array}{l}\text { Base } \\
\text { Year }\end{array}$ & $\begin{array}{l}\text { Base value }{ }^{(a)} \\
\text { billions kWh } \\
\end{array}$ & $\begin{array}{l}\text { Average } \\
\text { Annual } \\
\text { Growth } \\
\text { Rate, \% }\end{array}$ & $\begin{array}{l}\text { Fore- } \\
\text { Cast } \\
\text { Year }\end{array}$ & $\begin{array}{l}\text { Forecast } \\
\text { Value, } \\
\text { billions kwh }\end{array}$ & Reference \\
\hline DRI & 1985 & 2470 & 2.9 & 1995 & 3287 & 20 \\
\hline Koomanoff & 1983 & 2310 & 0.5 & 1990 & 2392 & 21 \\
\hline $\begin{array}{l}\text { DOE-CPPA } \\
\text { Scenario B }\end{array}$ & 1982 & 2241 & $\begin{array}{l}4.5 \\
3.2 \\
3.0 \\
2.8 \\
2.5\end{array}$ & $\begin{array}{l}1985 \\
1990 \\
1995 \\
2000 \\
2005\end{array}$ & $\begin{array}{l}2600 \\
2900 \\
3300 \\
3700 \\
4500\end{array}$ & 22 \\
\hline Scenario A & 1982 & 2241 & $\begin{array}{l}4.5 \\
2.9 \\
2.4 \\
2.2 \\
2.1 \\
1.9\end{array}$ & $\begin{array}{l}1985 \\
1990 \\
1995 \\
2000 \\
2005 \\
2010\end{array}$ & $\begin{array}{l}2600 \\
2800 \\
3100 \\
3300 \\
3600 \\
3800\end{array}$ & 23 \\
\hline Scenario C & 1982 & 2241 & $\begin{array}{l}4.5 \\
3.4 \\
3.1 \\
2.9 \\
2.7 \\
2.6\end{array}$ & $\begin{array}{l}1985 \\
1990 \\
1995 \\
2000 \\
2005 \\
2010\end{array}$ & $\begin{array}{l}2600 \\
2900 \\
3300 \\
3700 \\
4100 \\
4700\end{array}$ & 24 \\
\hline LOW GNP & 1982 & 2241 & $\begin{array}{l}2.6 \\
2.5 \\
2.0 \\
2.0 \\
2.0 \\
1.9\end{array}$ & $\begin{array}{l}1985 \\
1990 \\
1995 \\
2000 \\
2005 \\
2010\end{array}$ & $\begin{array}{l}2400 \\
2700 \\
2900 \\
3200 \\
3500 \\
3800\end{array}$ & 25 \\
\hline High GNP & 1982 & 2241 & $\begin{array}{l}5.8 \\
4.5 \\
3.7 \\
3.4 \\
3.2 \\
3.0\end{array}$ & $\begin{array}{l}1985 \\
1990 \\
1995 \\
2005 \\
2015 \\
2010\end{array}$ & $\begin{array}{l}2700 \\
3200 \\
3600 \\
4100 \\
4600 \\
5200\end{array}$ & 26 \\
\hline $\begin{array}{l}\text { Roles } \\
\text { Reference } \\
\text { Cases }\end{array}$ & 1980 & 2286 & $\begin{array}{l}3.5 \\
3.0 \\
3.1\end{array}$ & $\begin{array}{l}1990 \\
2000 \\
2010\end{array}$ & $\begin{array}{l}3200 \\
4100 \\
5700\end{array}$ & 27 \\
\hline
\end{tabular}

(a) Ail values converted to net generation basis. Base values are as reported by EIA. Net generation is approximately $9 \%$ greater than end use consumption. 
TABLE A.1. (contd)

\begin{tabular}{|c|c|c|c|c|c|c|}
\hline Source & $\begin{array}{l}\text { Base } \\
\text { Year }\end{array}$ & $\begin{array}{l}\text { Base value, }(\mathrm{a}) \\
\text { billions kWh } \\
\end{array}$ & $\begin{array}{l}\text { Average } \\
\text { Annual } \\
\text { Growth } \\
\text { Rate, } \%\end{array}$ & $\begin{array}{l}\text { Fore- } \\
\text { Cast } \\
\text { Year } \\
\end{array}$ & $\begin{array}{l}\text { Forecast) } \\
\text { Value, } \\
\text { billions kWh }\end{array}$ & Reference \\
\hline $\begin{array}{l}\text { Roles } \\
\text { (Enhanced) }\end{array}$ & 1980 & 2286 & 3.4 & 2010 & 6300 & 28 \\
\hline 0 il Co. A & 1982 & 2241 & 3.1 & 2000 & 3800 & 29 \\
\hline $0 i 1$ Co. D & 1982 & 2241 & 2.4 & 2000 & 3434 & 30 \\
\hline$A G A$ & 1982 & 2241 & 1.9 & 2000 & 3100 & 31 \\
\hline GRI & 1982 & 2241 & 2.7 & 2000 & 3600 & 32 \\
\hline DRI & 1982 & 2241 & 2.8 & 2000 & 3600 & 33 \\
\hline AES & 1982 & 2241 & 1.8 & 2000 & 3000 & 34 \\
\hline ORAU & 1982 & 2241 & 2.3 & 2000 & 3300 & 35 \\
\hline $\begin{array}{l}\text { Electrical } \\
\text { world }\end{array}$ & 1986 & 2487 & $\begin{array}{l}2.3 \\
2.3\end{array}$ & $\begin{array}{l}1995 \\
2000\end{array}$ & $\begin{array}{l}3052 \\
3442\end{array}$ & $\begin{array}{l}36 \\
36\end{array}$ \\
\hline $\begin{array}{l}\text { DOE (base) } \\
\text { (low growth) } \\
\text { (high growth) } \\
\text { (high demand) } \\
\text { (reduced } \\
\text { capacity) }\end{array}$ & $\begin{array}{l}1985 \\
1985 \\
1985 \\
1985 \\
1985\end{array}$ & $\begin{array}{l}2470 \\
2470 \\
2470 \\
2470 \\
2470\end{array}$ & $\begin{array}{l}2.8 \\
2.5 \\
3.0 \\
3.2 \\
2.8\end{array}$ & $\begin{array}{l}1995 \\
1995 \\
1995 \\
1995 \\
1995\end{array}$ & $\begin{array}{l}3242 \\
3176 \\
3313 \\
3401 \\
3250\end{array}$ & $\begin{array}{l}37 \\
37 \\
37 \\
37 \\
37\end{array}$ \\
\hline GRI & 1985 & $642(\mathrm{GW})$ & $\begin{array}{l}3.0 \\
2.2 \\
2.2 \\
2.0 \\
1.9\end{array}$ & $\begin{array}{l}1990 \\
1995 \\
2000 \\
2005 \\
2010\end{array}$ & $\begin{array}{r}744 \quad(\mathrm{GW}) \\
801 \\
883 \\
958 \\
1017\end{array}$ & 38 \\
\hline GRI & 1985 & 2470 & $\begin{array}{l}3.0 \\
3.3 \\
2.9 \\
2.6 \\
2.3\end{array}$ & $\begin{array}{l}1990 \\
1995 \\
2000 \\
2005 \\
2010\end{array}$ & $\begin{array}{l}2862(\mathrm{~b}) \\
3433(\mathrm{c}) \\
3785 \text { (c) } \\
4106 \text { (c) } \\
4359(\mathrm{c})\end{array}$ & 38 \\
\hline AER & 1985 & 2470 & 2.4 & 2000 & 3526 & 39 \\
\hline
\end{tabular}

\footnotetext{
(a) All values converted to net generation basis. Base values are as reported by EIA. Net generation is approximately 9\% greater than end use consumption.

(b) $44 \%$ system capacity factor.

(c) $49 \%$ system capacity factor.
} 
TABLE A.1. (contd)

\begin{tabular}{|c|c|c|c|c|c|c|}
\hline Source & $\begin{array}{l}\text { Base } \\
\text { Year }\end{array}$ & $\begin{array}{l}\text { Base value, }{ }^{(a)} \\
\text { billions kWh }\end{array}$ & $\begin{array}{l}\text { Average } \\
\text { Annual } \\
\text { Growth } \\
\text { Rate, \% }\end{array}$ & $\begin{array}{l}\text { Fore- } \\
\text { Cast } \\
\text { Year }\end{array}$ & $\begin{array}{l}\text { Forecast } \\
\text { Value, } \\
\text { billions kwh }\end{array}$ & Reference \\
\hline $\begin{array}{l}\text { Electrical } \\
\text { World }\end{array}$ & 1985 & 2470 & 2.5 & 2000 & 3577 & 40 \\
\hline NEMA & 1985 & 2470 & 2.0 & 1994 & 2952 & 40 \\
\hline NERC & 1985 & 2470 & 2.1 & 1995 & 3041 & 41 \\
\hline NERC & 1986 & 2487 & 1.9 & 1996 & 2990 & 42 \\
\hline NCA (Low) & 1987 & 2599 & 1.8 & 2000 & 3277 & 43 \\
\hline NCA (Moderate) & 1987 & 2599 & 2.2 & 2000 & 3449 & 43 \\
\hline NCA (High) & 1987 & 2599 & 2.6 & 2000 & 3628 & 43 \\
\hline EEI & 1987 & 2599 & 2.6 & 2000 & 3628 & 44 \\
\hline EEI & 1987 & 2599 & 2.0 & 2015 & 4525 & 44 \\
\hline $\begin{array}{l}\text { Electrical } \\
\text { World }\end{array}$ & 1987 & 2599 & 2.0 & 2000 & 3362 & 45 \\
\hline
\end{tabular}

(a) All values converted to net generation basis. Base values are as reported by EIA. Net generation is approximately 9\% greater than end use consumption. 
TABLE A.1. (contd)

Reference:

1-3 DOE, Energy Information Administration. "Annual Outlook for U.S. Electric Power 1985." DOE/EIA-0474 (85).

4-17 From William W. Hogan, "Energy Demand and the Outlook for Electricity." July 1985 in hearings before the Committee on Energy and Natural Resources, United States Senate, July 23 and 25, 1985. SHRG 99-253.

15 The Audubon forecast assumed the adoption of certain energy conservation policies that did not occur.

18 North American Electric Reliability Council. "1985 Electric Power Supply and Demand." Princeton, New Jersey.

19 Mark W. French. SHRG 99-253, p. 129.

20 Stephen A. Smith. SHRG 99-253, p. 148.

21 As reported in Siegel and Sillin, "Revitalizing Nuclear Power. The Case for Deregulation." Public Utilities Fortnightly, January 23, 1986.

22-26 DOE, Office of Policy, Planning and Analysis. "Energy Projections to the Year 2010" D0E PE-0029/2. October 1983.

27,28 DOE, Assistant Secretary for Nuclear Energy," The Role of Nuclear Power." DOE/NE-0054. July 1984.

29-35 Derived from data in D0E/PE-0029/2, p. 7-18.

36 Electrical world, September 1987, p. 37.

37 Annual Outlook for U.S. Electrical Power, 1986, D0E/EIA-0474 (86), p. 14.

38 Energy Daily, November 16, 1987, pp. 1-2; DOE/EIA-0474 (86), p. 14.

39 Public Utilities Fortnightly, April 30, 1987, p. 6; DOE/EIA-0474 (86), p. 14 .

40 Energy Security, DOE-0057/S, p. 137, March 1987.

41 NERC, "1986 Electricity Supply and Deinand," p. 34.

42 NERC, "1987 Electricity Supply and Demand," pp. 6 and 15. 
TABLE A.1. (contd)

43 National Coal Association, reported in Energy Daily, March 2, 1989, p. 2 .

44 EEI, reported in Energy Daily, February 9, 1989, pp. 1-2.

45 Electrical World, October 1988, pp. 67-72. 



\section{APPENDIX B}

PROJECTIONS OF THE RATIO OF ELECTRICITY DEMAND

GROWTH TO GNP GROWTH 
APPENDIX B

PROJECTIONS OF THE RATIO OF ELECTRICITY DEMAND

GROWTH TO GNP GROWTH

This appendix list projections of the ratio of electricity demand growth to GNP growth made by numerous forecasters. Both the mean and median values are slightly below unity. Many, probably most, electricity demand forecasts are based, at least partly, on an imputed relationship between electricity demand and GNP. Table B.2 lists several recent projections of GNP growth rates. Note that the average projection (excluding DOE) is 2.50, which when combined with the mean elasticity ratio 0.97 in Table $B .1$ converts to a projected growth rate of $2.4 \%$ for electricity demand. 
TABLE B.1. Projections of the Ratio of Electricity Demand Growth to GNP Growth

\begin{tabular}{|c|c|c|c|}
\hline Number & Source & Period & Ratio \\
\hline 1 & Siege ] & $1983-2000$ & 1.29 \\
\hline 2 & AEO & $1983-1995$ & 1.14 \\
\hline 3 & Data Resources, Inc. & $1983-2000$ & 1.07 \\
\hline 4 & DOE & $1982-2000$ & 1.00 \\
\hline 5 & Electrical World & $1983-2000$ & 0.97 \\
\hline 6 & Dept. of Commerce & $1983-2000$ & 0.93 \\
\hline 7 & National Coal Assocication & $1982-1995$ & 0.92 \\
\hline 8 & Wharton & $1983-1994$ & 0.91 \\
\hline 9 & GRI & $1983-2000$ & 0.86 \\
\hline 10 & Conoco, Inc. & $1982-2000$ & 0.75 \\
\hline 11 & R. W. Sant & $1980-2000$ & 0.58 \\
\hline 12 & National Audubon Society & $1980-2000$ & -0.32 \\
\hline 13 & DRI & $1985-1995$ & 1.00 \\
\hline 14 & Roles-Reference & $1980-2010$ & 1.15 \\
\hline 15 & Roles-Enhanced & $1980-2010$ & 1.13 \\
\hline 16 & $\begin{array}{l}\text { DOE-OPPA } \\
\text { Scenario B }\end{array}$ & $1982-2010$ & 0.96 \\
\hline 17 & Scenario A & $1982-2010$ & 0.79 \\
\hline 18 & Scenario $\mathrm{C}$ & $1982-2010$ & 1.04 \\
\hline 19 & LOW GNP & $1982-2010$ & 0.87 \\
\hline 20 & High GNP & $1982-2010$ & 1.06 \\
\hline 21 & DOE-EIA (Middle) & $1985-1990$ & 1.10 \\
\hline 22 & DOE-EIA (Middle) & $1991-1995$ & 1.35 \\
\hline 23 & DOE-EIA (Middle) & $1985-1995$ & 1.19 \\
\hline 24 & DOE-EIA (LOW) & $1985-1995$ & 1.35 \\
\hline 25 & DOE-EIA (High) & $1985-1995$ & 1.12 \\
\hline 26 & $0 i 1 \mathrm{CO} . \mathrm{A}$ & $1982-2000$ & 1.11 \\
\hline 27 & $0 i 1 \mathrm{CO} . \mathrm{B}$ & $1982-2000$ & 1.00 \\
\hline 28 & $A G A$ & $1982-2000$ & 0.66 \\
\hline 29 & GRI & $1982-2000$ & 1.04 \\
\hline
\end{tabular}


IABLE B.1. (contd)

\begin{tabular}{|c|c|c|c|}
\hline Number & Source & Period & Ratio \\
\hline 30 & DRI & $1982-2000$ & 1.00 \\
\hline 31 & AES & $1982-2000$ & 0.69 \\
\hline 32 & ORAU & $1982-2000$ & 0.79 \\
\hline 33 & Electrical World & $\begin{array}{l}1986-1995 \\
1986-2000\end{array}$ & $\begin{array}{l}0.97 \\
1.00\end{array}$ \\
\hline 34 & $\begin{array}{l}\text { DOE-EIA } \\
\text { LOw Growth } \\
\text { Base } \\
\text { High Growth } \\
\text { High Electricity Demand } \\
\text { Reduced Capacity }\end{array}$ & $\begin{array}{l}1985-1995 \\
1985-1995 \\
1985-1995 \\
1985-1995 \\
1985-1995\end{array}$ & $\begin{array}{l}1.04 \\
0.98 \\
0.94 \\
0.91 \\
0.99\end{array}$ \\
\hline 35 & National Coal Association & $1985-2000$ & 0.91 \\
\hline 36 & Department of Commerce & $1985-2000$ & 0.96 \\
\hline 37 & ICF, Inc. & $1985-2000$ & 0.85 \\
\hline 38 & Data Resources & $1985-2000$ & 1.00 \\
\hline 39 & GRI & $1985-2000$ & 0.67 \\
\hline 40 & Electrical World & $1985-2000$ & 1.00 \\
\hline 41 & Applied Energy Services & $1985-2000$ & 0.93 \\
\hline 42 & Wharton & $1985-2000$ & 0.86 \\
\hline 43 & DOE & $1985-2000$ & 0.86 \\
\hline 44 & Electrical World & $1987-2000$ & 0.96 \\
\hline 45 & EEI & $1987-2000$ & 1.04 \\
\hline 46 & EEI & $1987-2015$ & 0.87 \\
\hline 47 & $N C A$ - Low & $1987-2000$ & 0.78 \\
\hline 48 & NCA - Moderate & $1987-2000$ & 0.96 \\
\hline \multirow[t]{5}{*}{49} & NCA - High & $1987-2000$ & 1.13 \\
\hline & & Mean & $0.97^{(a)}$ \\
\hline & & Median & 0.97 \\
\hline & & Median w/o DOE & $0.96^{(b)}$ \\
\hline & & Median recent & $0.96^{(c}$ \\
\hline
\end{tabular}


TABLE B.1. (contd)

\begin{tabular}{|c|c|}
\hline Number & Period \\
\hline \multicolumn{2}{|c|}{ References: } \\
\hline $1-12$ & Hogan op. cit., p. 96 \\
\hline 13 & Smith op. cit., p. 149 \\
\hline $14-15$ & DOE, Assistant Secretary of Nuclear Energy, op. cit. \\
\hline $16-20$ & DOE, Office of Policy, Planning and Analysis, op. cit. \\
\hline $21-25$ & DOE, EIA - 0474 (85) op. cit. \\
\hline $26-32$ & Derived from DOE (PE-0029/2, pp. $7-13$ and $7-18$ ) \\
\hline 33 & $\begin{array}{l}\text { Derived from Electrical World, September, 1987, pp. } 37 \\
\text { and } 38 \text {. }\end{array}$ \\
\hline 34 & Derived from DOE/EIA-0474 (86), pp. 14 and 21 \\
\hline $35-43$ & Derived from DOE-0057/S, March 1987, p. 137 \\
\hline 44 & Derived from Electrical World, October 1988, pp. 67-72 \\
\hline $45-46$ & Derived from Energy Daily, February 9, 1989, pp. 1-2. \\
\hline $47-49$ & Derived from Energy Daily, March 2, 1989, p. 2 . \\
\hline
\end{tabular}

(a) Excluding Audubon projection.

(b) Excluding all DOE projections.

(c) Most recent projections, references 33-49. 
TABLE B.2. GNP Projections

\begin{tabular}{|c|c|c|c|}
\hline Number & Source & Period & $\begin{array}{c}\text { Annual } \\
\text { Growth } \\
\text { Rate }(\%)\end{array}$ \\
\hline 1 & Electrical world & $1986-2000$ & 2.4 \\
\hline 2 & $\begin{array}{l}\text { DOE/EIA } \\
\text { LOw Growth } \\
\text { Base } \\
\text { High Growth } \\
\text { High Electricity Demand } \\
\text { Reduced Capacity }\end{array}$ & $\begin{array}{l}1985-1995 \\
1985-1995 \\
1985-1995 \\
1985-1995 \\
1985-1995\end{array}$ & $\begin{array}{l}2.4 \\
2.8 \\
3.2 \\
3.6 \\
2.8\end{array}$ \\
\hline 3 & National Coal Association & $1985-2000$ & 2.3 \\
\hline 4 & Department of Commerce & $1985-2000$ & 2.5 \\
\hline 5 & ICF, Inc. & $1985-2000$ & 2.6 \\
\hline 6 & Data Resources & $1985-2000$ & 2.6 \\
\hline 7 & GRI & $1985-2000$ & 2.7 \\
\hline 8 & Electrical Worid & $1985-2000$ & 2.5 \\
\hline 9 & Applied Energy Service & $1985-2000$ & 2.8 \\
\hline 10 & wharton & $1985-2000$ & 2.9 \\
\hline 11 & DOE & $1985-2000$ & 2.9 \\
\hline 12 & Electrical World & $1987-2000$ & 2.1 \\
\hline 13 & EEI & $1987-2000$ & 2.5 \\
\hline 14 & EEI & $1987-2015$ & 2.3 \\
\hline 15 & NCA & $1987-2000$ & 2.3 \\
\hline \multicolumn{3}{|c|}{ Average } & 2.64 \\
\hline \multicolumn{3}{|c|}{ Average W/O DOE } & 2.50 \\
\hline \multicolumn{4}{|c|}{ Reference: } \\
\hline 1 & \multicolumn{3}{|l|}{ September 1986, p. 36} \\
\hline 2 & \multicolumn{3}{|c|}{ DOE/EIA-0474, "Annual Low Outlook for Electric Power," 1986, p. 13.} \\
\hline $3-11$ & \multicolumn{3}{|c|}{$\mathrm{DOE}-0057 / \mathrm{S}$, p. 137} \\
\hline 12 & \multicolumn{3}{|l|}{ October 1988, p. 68.} \\
\hline $13-14$ & \multicolumn{3}{|c|}{ Energy Daily, February 9, 1989, pp. 1-2. } \\
\hline 15 & \multicolumn{3}{|c|}{ Energy Daily, March 2, 1989, p. 2} \\
\hline
\end{tabular}




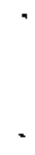




\section{NORTH AMERICAN ELECTRIC RELIABILITY COUNCIL}

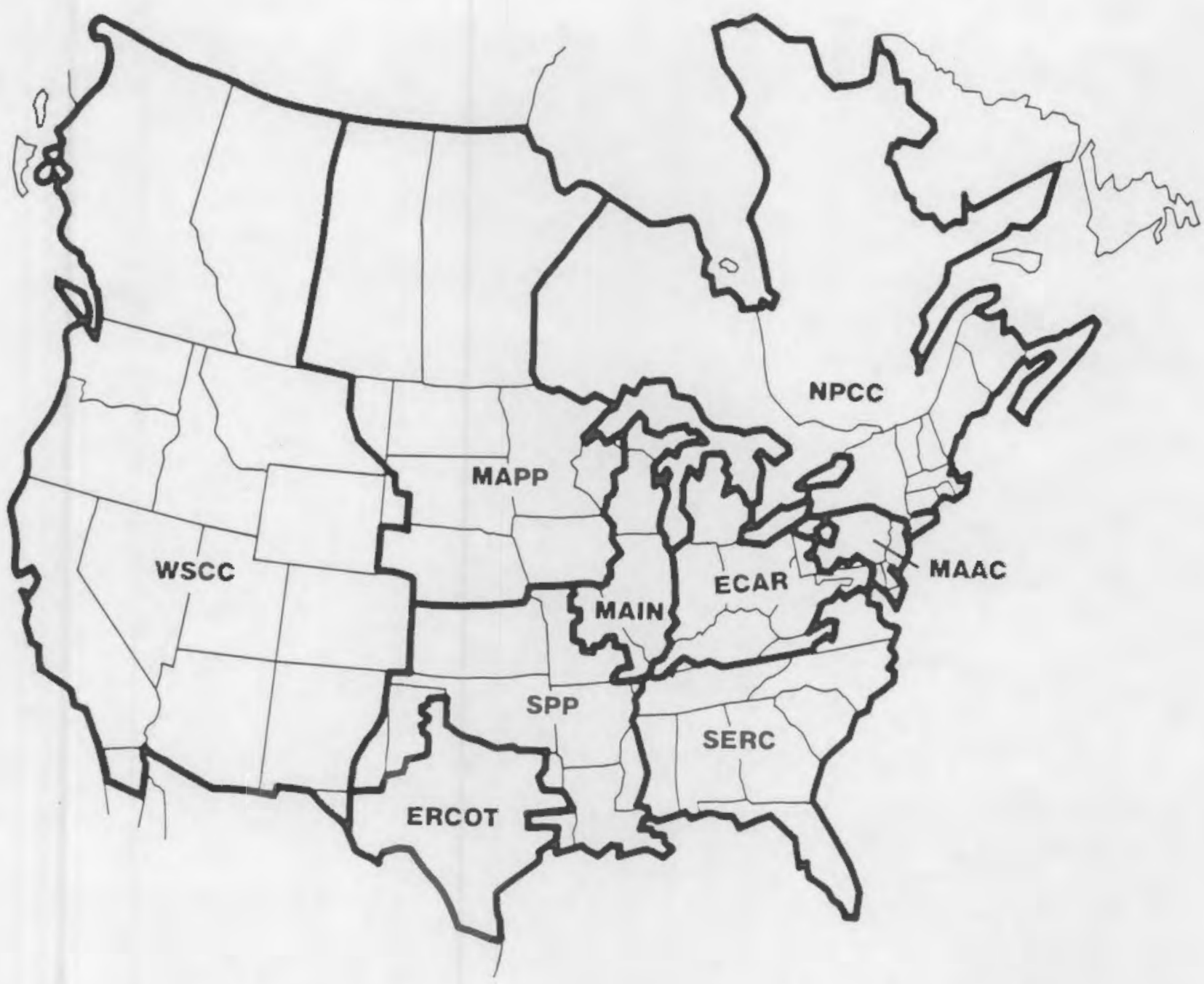

ECAR

East Central Area Reliability Coordination Agreement

EACOT

Electric Reliability Council of Texas

MAAC

Mid-Atlantic Area Council

MAIN

Mid-America Interconnected Network

MAPP

Mid-continent Area Power Pool

NPCC

Northeast Power Coordinating Council
SERC

Southeastern Electric Reliability Council SPP

Southwest Power Pool

wSCC

Western Sylems Coordinating Council

Copyright ' 1987 by Nivth American Electric Reliability Council. All rights reverved. 

APPENDIX D

LOAD DURATION CURVES 


\section{APPENDIX D}

\section{LOAD DURATION CURVES}

The need for each type of capacity is determined by the shape of the load duration curve. A typical load duration curve is illustrated in Figure D.1. The load duration curve shows the hours of operation (abscissa) at each load level (ordinate) throughout the year. The three types of capacity (base, intermediate, and peak) are shown on the right vertical axis. The boundaries between each type are somewhat arbitrary. Assuming that the area, $M$, under the line $A B C$ represents the electricity generated by the baseload capacity, then the average capacity factor for the baseload capacity is $M /(M+N)$. Similarly, assuming that the area $P$ is generated by the intermediate load capacity, then the average capacity factor for the intermediate load capacity is $P /(P+Q)$. Correspondingly, the average capacity factor for the peak load capacity is $R /(R+S)$. Collectively, the average capacity factor of the entire system is $(R+P+M) /(R+P+M+S+Q+N)$. The fraction of electricity generated by the baseload capacity is $M /(M+P+R)$; this is typically on the order of $80 \%$ in many systems. Note that if outages occur in the baseload capacity, particularly during the hours from $A$ to $B$, the baseload capacity would not be able to supply $M$ amount of energy. The deficit in that case would be made up by the other capacity. The area $\mathrm{N}$ is mainly used for scheduled outages of base load capacity.

The distribution of the need for baseload or peak load capacity is profoundly impacted by the shape of the load duration curve. This is easily illustrated by two hypothetical extreme examples (Figures D.2 and D.3). In Figure D.2, the need for peaking capacity far exceeds the need for baseload capacity. In Figure D.3, the reverse is true. 


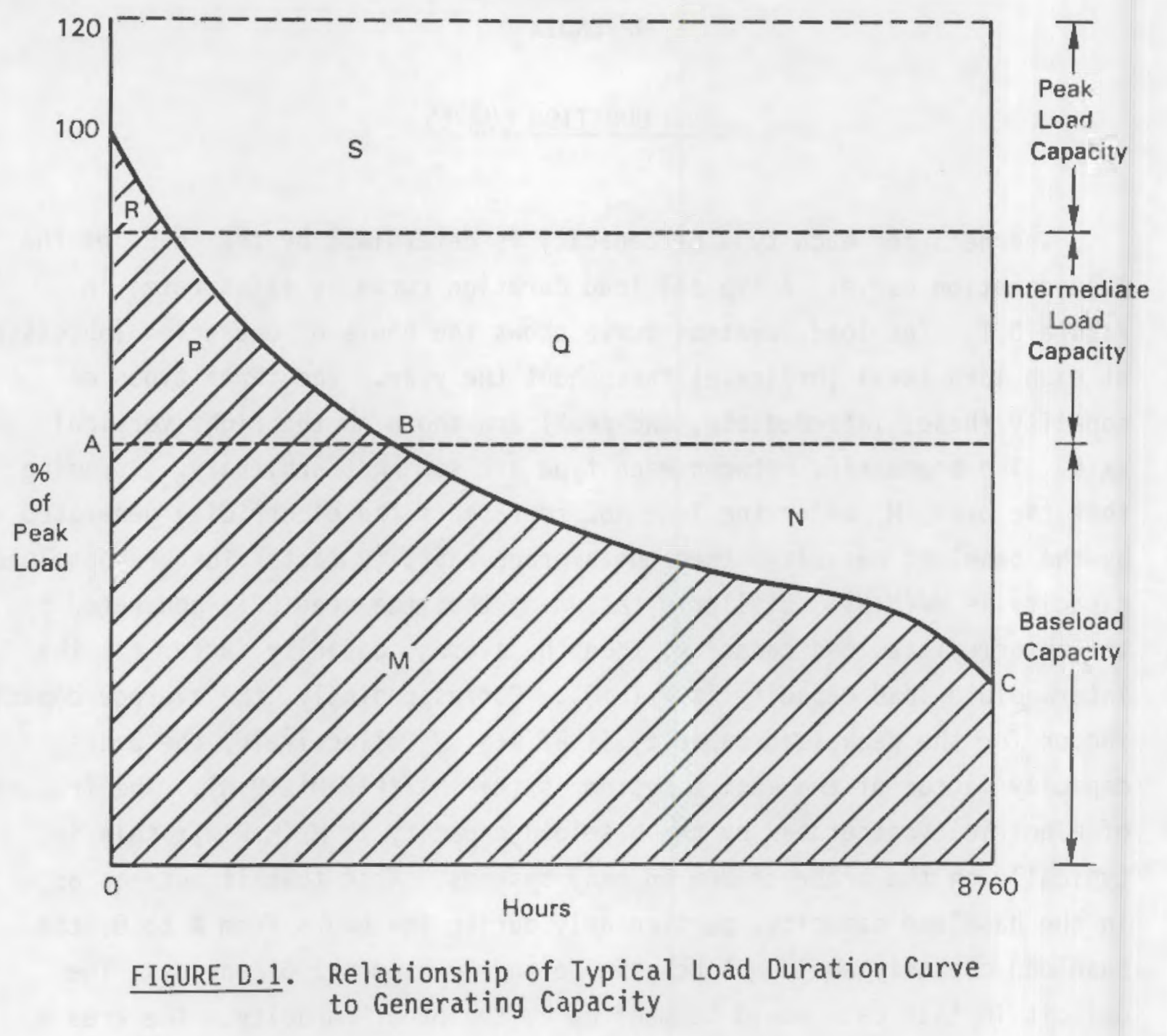




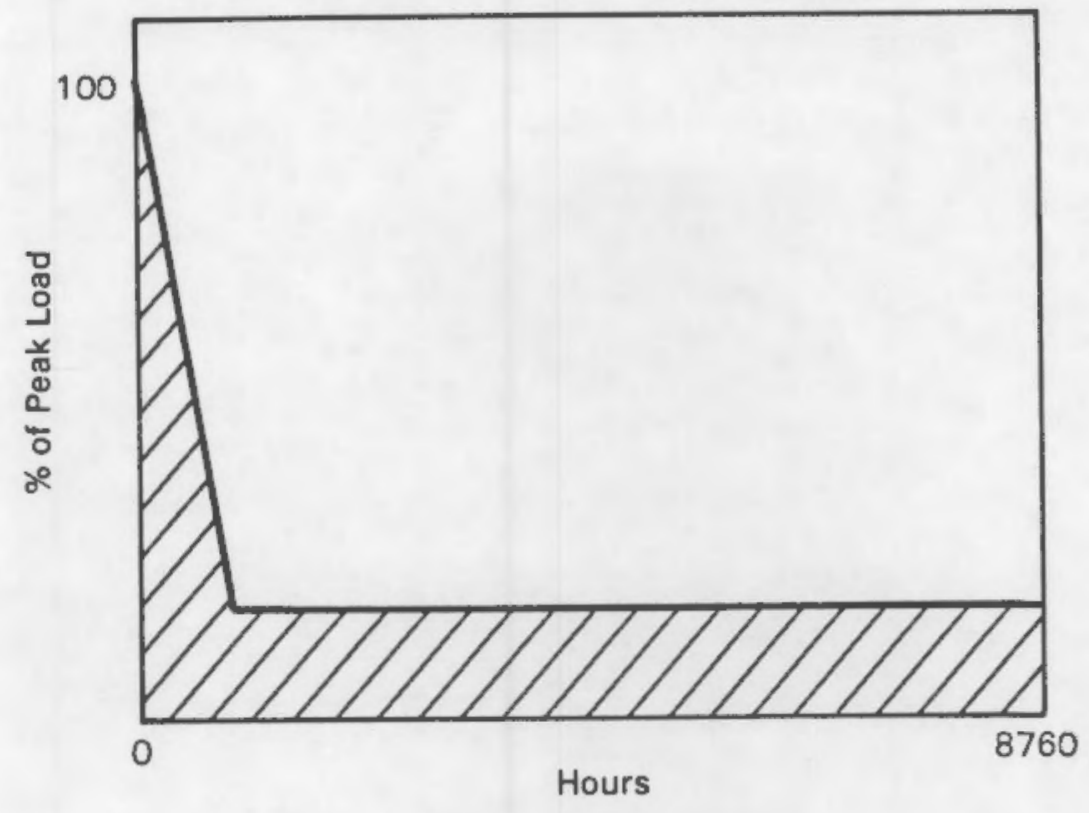

FIGURE D.2. Low Baseload Example

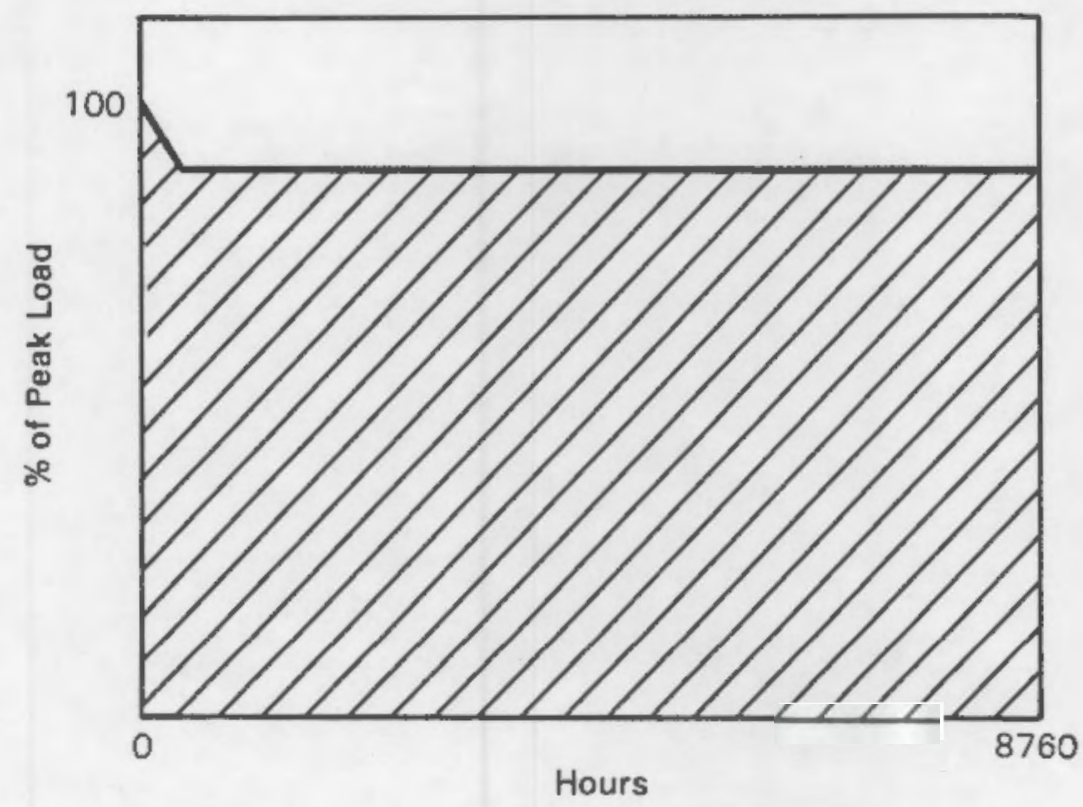

FIGURE D.3. High Baseload Example

Hypothetical Examples Illustrating Extreme Diversity in Load Duration Curve 

APPENDIX E

CAPACITY PROJECTIONS 


\section{APPENDIX E}

\section{CAPACITY PROJECTIONS}

Capacity projections for each of the scenarios are summarized for selected years on page E.2. The base year is 1987. Yearly capacity projections are shown on page E.3 for the three scenarios; years 1984 through 1987 are historical data. Years 1988 through 1996 corresponds to NERC plans until additional capacity is required, i.e., 1992 for the high scenarios, 1995 for the middle scenarios, and 2000 for the low scenario. 
Projected Peak Demand

\begin{tabular}{|c|c|c|c|c|c|c|c|}
\hline Year & Low & Middle & High & Year & Low & Middle & High \\
\hline 1987 & 494 & 494 & 494 & 1987 & 593 & 593 & 593 \\
\hline 1996 & 565 & 617 & 673 & 1996 & 678 & 740 & 808 \\
\hline 2005 & 646 & 770 & 918 & 2005 & 775 & 925 & 1101 \\
\hline 2015 & 750 & 986 & 1294 & 2015 & 899 & 1184 & 1553 \\
\hline 2025 & 870 & 1263 & 1826 & 2025 & 1044 & 1515 & 2191 \\
\hline 2037 & 1040 & 1698 & 2759 & 2037 & 1248 & 2038 & 3311 \\
\hline
\end{tabular}

\section{Capacity Requirements}

Incremental Capacity Requirements

\begin{tabular}{lrrr} 
Year & Low & Middle & High \\
\cline { 1 - 2 } 1996 & -38 & 24 & \\
2005 & 59 & 209 & 385 \\
2015 & 183 & 468 & 837 \\
2025 & 328 & 799 & 1475 \\
2037 & 532 & 1322 & 2595
\end{tabular}

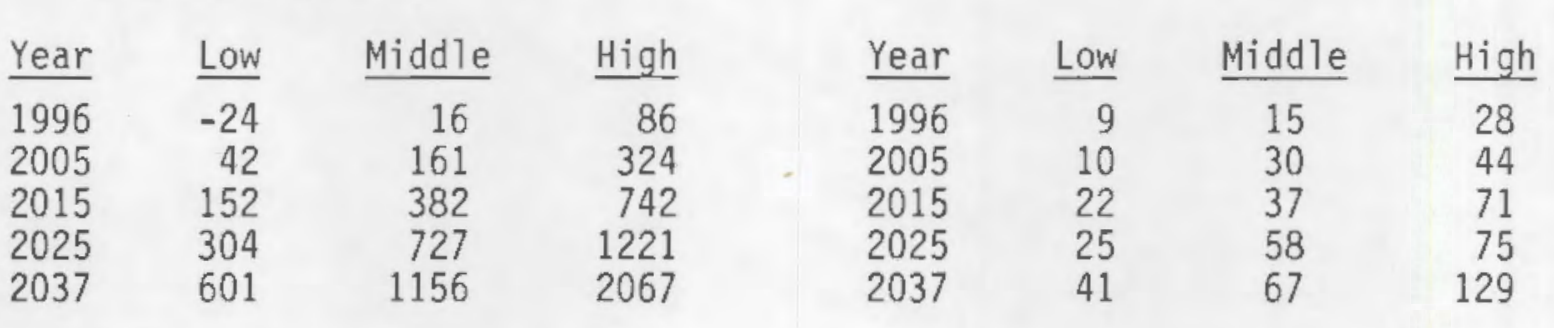

Cumulative Capacity Retired

$\begin{array}{rrrr}\frac{\text { Year }}{1996} & \text { Low } & \text { Middle } & \text { High } \\ 2005 & 9 & 13 & 62 \\ 2015 & 81 & 71 & 165 \\ 2025 & 190 & 180 & 410 \\ 2037 & 481 & 624 & 571 \\ & 617 & 861\end{array}$

Cumulative Need for New Baseload Capacity

Annual Need for New Capacity$$
\text { Year }
$$

Annual Need for New Baseload Capacity

\begin{tabular}{|c|c|c|c|}
\hline Year & Low & Middle & High \\
\hline 1996 & 6 & 9 & 17 \\
\hline 2005 & 6 & 18 & \\
\hline 2015 & 13 & 22 & 42 \\
\hline 202 & 15 & 35 & 45 \\
\hline 2037 & 25 & 40 & 77 \\
\hline
\end{tabular}




\begin{tabular}{|c|c|c|c|}
\hline \multirow[b]{2}{*}{ Year } & \multicolumn{3}{|c|}{ Capacity Projections } \\
\hline & Low (a) & Likely (b) & High(c) \\
\hline 1984 & 604 & 604 & 604 \\
\hline 1985 & 617 & 617 & 617 \\
\hline 1986 & 633 & 633 & 633 \\
\hline 1987 & 647 & 647 & 647 \\
\hline 1988 & 662 & 662 & 662 \\
\hline 1989 & 674 & 674 & 674 \\
\hline 1990 & 681 & 681 & 681 \\
\hline 1991 & 690 & 696 & 690 \\
\hline 1992 & 694 & 694 & 704 \\
\hline 1993 & 699 & 698 & 729 \\
\hline 1994 & 765 & 705 & 754 \\
\hline 1995 & 710 & 722 & 781 \\
\hline 1996 & 716 & 740 & 808 \\
\hline 1997 & 716 & 759 & 836 \\
\hline 1998 & 716 & 778 & 865 \\
\hline 1999 & 716 & 797 & 896 \\
\hline 2000 & 719 & 817 & 927 \\
\hline 2001 & 730 & 838 & 960 \\
\hline 2002 & 741 & 859 & 993 \\
\hline 2003 & 752 & 880 & 1028 \\
\hline 2064 & 764 & 902 & 1064 \\
\hline 2005 & 775 & 925 & 1101 \\
\hline 2006 & 787 & 948 & 1146 \\
\hline 2007 & 798 & 971 & 1180 \\
\hline 2008 & 810 & 996 & 1221 \\
\hline 2009 & 823 & 1021 & 1264 \\
\hline 2010 & 835 & 1046 & 1368 \\
\hline 2011 & 847 & 1072 & 1354 \\
\hline 2012 & 860 & 1699 & 1401 \\
\hline 2013 & 873 & 1126 & 1450 \\
\hline 2014 & 886 & 1155 & 1501 \\
\hline 2015 & 899 & 1184 & 1553 \\
\hline 2016 & 913 & 1213 & 1608 \\
\hline 2617 & 927 & 1243 & 1664 \\
\hline 2018 & 946 & 1275 & 1722 \\
\hline 2019 & 955 & 1306 & 1782 \\
\hline $202 \theta$ & 969 & 1339 & 1845 \\
\hline 2021 & 983 & 1373 & 1909 \\
\hline 2022 & 998 & 1467 & 1976 \\
\hline 2923 & 1013 & 1442 & 2045 \\
\hline 2024 & 1028 & 1478 & 2117 \\
\hline 2625 & 1644 & 1515 & 2191 \\
\hline 2026 & 1659 & 1553 & 2268 \\
\hline 2027 & 1075 & 1592 & 2347 \\
\hline 2028 & 1691 & 1631 & 2429 \\
\hline 2029 & 1168 & 1672 & 2514 \\
\hline 2936 & 1124 & 1714 & 2662 \\
\hline 2031 & 1141 & 1757 & 2693 \\
\hline 2032 & 1158 & 1801 & 2788 \\
\hline 2933 & 1178 & 1846 & 2885 \\
\hline 2034 & 1193 & 1892 & 2986 \\
\hline 2035 & 1211 & 1939 & 3091 \\
\hline 2836 & 1236 & 1988 & 3199 \\
\hline 2037 & 1248 & 2638 & 3311 \\
\hline
\end{tabular}

(a) Low indicates a growth rate of $1.5 \%$ per year and 60 year life.

(b) Likely indicates a growth rate of $2.5 \%$ per year and 50 year life.

(c) High indicates a growth rate of $3.5 \%$ per year and 40 year life.

Note that early years are history or NERC plans.

E.3 

APPENDIX F

TABULATION OF RESOURCE CONSUMPTION AND WASTE GENERATION FOR THREE GROWTH SCENARIOS 
APPENDIX F

TABULATION OF RESOURCE CONSUMPTION AND WASTE GENERATION

FOR THREE GROWTH SCENARIOS

The electricity generation, resource requirements, and waste generation for the three growth scenarios and three supply options are tabulated in this appendix.

\section{ASSUMPTIONS USED IN THE SCENARIOS}

We assumed that the proportion of coal plus nuclear generation to the total generation would remain constant at $68 \%$. (a) As noted earlier, coal plus nuclear electricity generation was $72 \%$ of the internal generation in 1987 and is expected to remain near $72 \%$ through 1997 . Thus, $68 \%$ is a conservative assumption over the next decade or two.

We assumed that the coal and nuclear plants now under construction would be completed by 1996 according to NERC plans. We further assumed that the nuclear plants would gradually increase their average capacity factor from $60 \%$ in 1984 to $65 \%$ in the year 2000 .

In the all-coal scenarios, no new nuclear plants are ordered. If the coal plus nuclear generation based on NERC plans exceeds $68 \%$ of the total generation projected for any year, the planned NERC generation for coal is used and nuclear is cut back. The nuclear plants are retired in 40,50 , or

(a) By implication we assume that 32 percent of the future electricity generation will come from other fuels. We expect those to be hydro, natural gas, oil, geothermal, solar, biomass, refuse, waste heat, etc. Current trends point to a decline in the percentage of hydro, natural gas, and oil used in utility generation. If the trends continue, this assumption would imply substantial growth in the alternative generation technologies and in non-utility generation. Much of this growth during the next ten years will come from non-utility generators (NUG). The fuel usage identified to date by the NUG is predominately natural gas, followed by coal and geothermal. The fuel type for most of the planned capacity additions by the NUG has not yet been specified. 
60 years after startup according to the growth scenario. The coal generation is calculated by subtracting the nuclear generation from the total coal plus nuclear generation.

In the all-nuclear scenarios, coal generation is calculated as above for nuclear. This generation is reduced year-by-year in proportion to the generation capacity retired, assuming a 40,50 , or 60 year plant life as appropriate. The nuclear generation is then obtained by difference.

The impacts of the half-coal/half-nuclear scenarios were estimated to be midway between the all-coal and all-nuclear scenarios.

The calculations are based on state-of-the-art technology assumptions (Appendix G). Improvements in technology could reduce fuel requirements and/or impacts. For simplicity, all steps of each fuel cycle were assumed to occur in the same year as electricity production. 
Low Grouth Scenario

Electricity Ceneration (Billions of kWh)

\begin{tabular}{|c|c|c|c|c|c|c|}
\hline \multirow[b]{2}{*}{ Year } & \multicolumn{2}{|c|}{ All Coal Case } & \multicolumn{2}{|c|}{$56 / 50$ Case } & \multicolumn{2}{|c|}{ All Nuclear Case } \\
\hline & Coal & Nuclear & Coal & Nuclear & Coal & Kuclear \\
\hline 1995 & 1549 & 478 & 1487 & 558 & 1386 & 839 \\
\hline 2665 & 1709 & B41 & 1631 & 719 & 1553 & 797 \\
\hline 2015 & 2086 & 641 & 1754 & 974 & 1421 & 1366 \\
\hline 2625 & 2525 & 640 & 1858 & 1315 & 1175 & 1990 \\
\hline 2937 & 3401 & 383 & 1958 & 1826 & 515 & 3269 \\
\hline Total & 105553 & 28688 & 84878 & 49781 & 63863 & 70636 \\
\hline
\end{tabular}

Nunber of 100 Car Coal Trains

\begin{tabular}{|c|c|c|}
\hline \multirow[b]{2}{*}{ Year } & \multicolumn{2}{|c|}{ All Coal Case } \\
\hline & Cool & Nuclear \\
\hline 1995 & 69687 & $\theta$ \\
\hline 2805 & 76894 & - \\
\hline 2015 & 93871 & s \\
\hline 2025 & 113819 & 0 \\
\hline 2937 & $153 \% 50$ & - \\
\hline
\end{tabular}

\begin{tabular}{|c|c|}
\hline $58 \mathrm{~b}$ & Case \\
\hline Coal & Nuclear \\
\hline 66628 & $\theta$ \\
\hline 73486 & 10 \\
\hline 78912 & 6 \\
\hline 83245 & 0 \\
\hline 88122 & 6 \\
\hline 3816519 & b \\
\hline
\end{tabular}

All Nuclear Case

Coal Nuclear

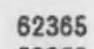

69998

83953

52870

23195

2871147

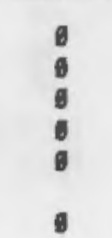

Millions of Tons of Coal or Ore Mined

\begin{tabular}{|c|c|c|c|c|c|c|}
\hline \multirow[b]{2}{*}{ Year } & \multicolumn{2}{|c|}{ All Coal Case } & \multicolumn{2}{|c|}{ 50/50 Case } & \multicolumn{2}{|c|}{ All Nuclear Case } \\
\hline & Coal & Nuclear & Coal & Nuclear & Coal & Nuclear \\
\hline 1995 & 746 & 13 & 767 & 16 & 668 & 18 \\
\hline 2095 & 824 & 18 & 786 & 20 & 749 & 22 \\
\hline 2615 & 1095 & 18 & 645 & 27 & 685 & 36 \\
\hline 2025 & 1217 & 18 & 892 & 37 & 568 & 55 \\
\hline 2637 & 1839 & 11 & 944 & 51 & 248 & 91 \\
\hline
\end{tabular}

Annual Rate of Change in Generation for Selected Years Percent Change from Previous Year

\begin{tabular}{|c|c|c|c|c|c|}
\hline \multirow[b]{2}{*}{ Year } & \multirow{2}{*}{$\frac{\text { All Coal Case }}{\text { Coal Nuclear }}$} & \multicolumn{2}{|c|}{$50 / 50$ C250 } & \multicolumn{2}{|c|}{ All Nuclear Case } \\
\hline & & Coal & Nucloar & Coal & Nuclear \\
\hline & $1.8 \%$ & $1.8 \mathrm{x}$ & $6.7 \mathrm{n}$ & & $6.7 x$ \\
\hline & $2.1 \mathrm{x}$ & 1.6\% & $2.8 \%$ & & $4.7 \%$ \\
\hline & $2.6 x$ & 5. BX & $3.2 x$ & & 4.8\% \\
\hline & $1.9 x$ & $6.6 \times$ & $2.8 x$ & & $3.8 x$ \\
\hline 26: & $2.7 \%$ & 6. $8 \mathrm{x}$ & $2.3 x$ & & $3.6 \%$ \\
\hline
\end{tabular}

Millions of Tons of Carbon Dioxide Released

\begin{tabular}{|c|c|c|c|c|c|c|}
\hline \multirow[b]{2}{*}{ Year } & \multicolumn{2}{|c|}{ All Coal Case } & \multicolumn{2}{|c|}{ 50/50 Case } & \multicolumn{2}{|c|}{ All Nuclear Case } \\
\hline & Coal & Nuclear & Coal & Nuclear & Co21 & Nuclear \\
\hline 1995 & 2613 & $\theta$ & 1987 & ต & 1802 & 6 \\
\hline & 2221 & ( & 2120 & 6 & 2026 & 0 \\
\hline & 2712 & 6 & 2280 & g & 1848 & 0 \\
\hline 20 & 3282 & - & 2465 & 0 & 1527 & 0 \\
\hline & 4421 & 0 & 2548 & g & 678 & t \\
\hline & 137219 & - & 110682 & - & 82944 & 由 \\
\hline
\end{tabular}

Thousands of Cubic Yards of Nonradioactive Solids

\begin{tabular}{|c|c|c|}
\hline & All Coa & Case \\
\hline Year & Con & Ruclear \\
\hline 1995 & 162234 & 4 \\
\hline 2665 & 112794 & 5 \\
\hline 2815 & 137678 & 5 \\
\hline 2925 & 168659 & 5 \\
\hline 2037 & 224466 & 3 \\
\hline
\end{tabular}

\begin{tabular}{rrr}
\multicolumn{2}{c}{$50 / 50$} & Case \\
\cline { 1 - 1 } Co2 & Nuclear \\
\cline { 1 - 1 } 96822 & & 4 \\
107646 & & 6 \\
115764 & & 8 \\
122166 & & 16 \\
129228 & & 14
\end{tabular}

All Nuclear Case Coal Nuclear

91478
162498

102498
93788

9378

33999

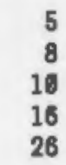

4216998

551 
Low Growth Scenario (contd)

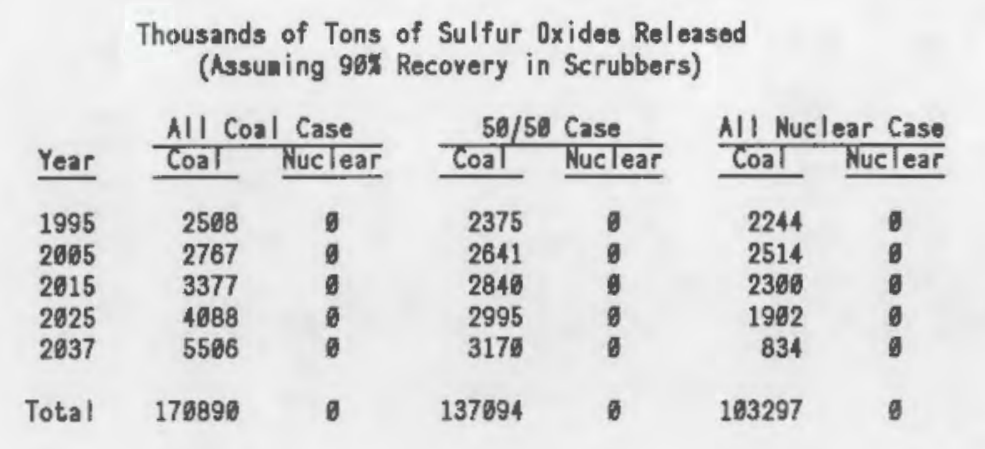

Thousands of Tons of Coal or Uraniun Shipped

\begin{tabular}{|c|c|c|c|c|c|c|}
\hline \multirow[b]{2}{*}{ Year } & \multirow{2}{*}{$\begin{array}{l}\text { All Coal } \\
\text { Coal }\end{array}$} & \multirow{2}{*}{$\begin{array}{l}\text { Case } \\
\text { Nuclear }\end{array}$} & \multicolumn{2}{|c|}{ 50/50 Case } & \multicolumn{2}{|c|}{ AlI Nuclear Case } \\
\hline & & & Coal & Nuclear & Coal & Nuclear \\
\hline 1995 & 627183 & 17 & 594233 & 20 & 561283 & 22 \\
\hline 2665 & 692643 & 22 & 666599 & 25 & 629155 & 28 \\
\hline 2815 & 844843 & 22 & 719269 & 34 & 575575 & 46 \\
\hline 2025 & 1022573 & 22 & 749263 & 46 & 475833 & 76 \\
\hline 2037 & 1377449 & 13 & 793102 & 64 & 268758 & 114 \\
\hline ota & 42749015 & 1011 & 34294669 & 1742 & 25840323 & 2472 \\
\hline
\end{tabular}

Requi rements* for Spent Fuel Shipments Assuming Rai

$$
\text { (Nultiply by Six for Truck) }
$$

Year Coal Nuclear Coal Nuclear $\quad$ Coal Nuclear

\begin{tabular}{|c|c|c|c|c|c|c|}
\hline 1995 & 0 & 0 & (0) & 351 & 0 & 463 \\
\hline 2095 & 0 & 464 & $g$ & 453 & 0 & 562 \\
\hline 2015 & $\theta$ & 404 & g & 613 & 0 & B23 \\
\hline 2625 & 0 & 493 & $\theta$ & 829 & 6 & 1254 \\
\hline 2037 & 0 & 241 & 0 & 1150 & 0 & 2859 \\
\hline Total & 0 & 18198 & 0 & 31349 & 6 & 44561 \\
\hline
\end{tabular}

Thousands of Tons of Oxides of Mitrogen Released (Assuming Maxinun Allowable Released)

\begin{tabular}{|c|c|c|c|c|c|c|}
\hline \multirow[b]{2}{*}{ Year } & \multicolumn{2}{|c|}{ All Coal Case } & \multicolumn{2}{|c|}{$50 / 50$ Caso } & \multicolumn{2}{|c|}{ All Nuclear Case } \\
\hline & Coal & Nuclear & Coal & Nuclear & Con & Nuclear \\
\hline 1995 & 3484 & (1) & 3301 & 6 & 3118 & G \\
\hline 2065 & 3845 & g & 3670 & 0 & 3495 & (1) \\
\hline 2915 & 4694 & g & 3946 & 0 & 3198 & 0 \\
\hline 2925 & 5681 & 6 & 4162 & 0 & 2644 & 8 \\
\hline 2037 & 7652 & 6 & 4466 & g & 1160 & 6 \\
\hline Total & 237495 & 0 & 196526 & $\theta$ & 143557 & 由 \\
\hline
\end{tabular}

Thousands of Cubic iards of Low Level Radioactive Waste

\begin{tabular}{|c|c|c|c|c|c|c|}
\hline \multirow[b]{2}{*}{ Year } & \multicolumn{2}{|c|}{ All Coal Case } & \multicolumn{2}{|c|}{$5 \% / 50$ Case } & \multicolumn{2}{|c|}{ All Nuclear Case } \\
\hline & Coal & Nuclear & Coa & Nuclear & Coal & Nuclear \\
\hline 1995 & g & 67 & 0 & 78 & 6 & 89 \\
\hline 2005 & g & 99 & ø & 101 & 0 & 112 \\
\hline 2015 & 6 & 90 & 6 & 136 & 0 & 183 \\
\hline 2025 & b & 90 & 6 & 184 & g & 279 \\
\hline 2037 & 6 & 54 & 6 & 256 & 6 & 458 \\
\hline Total & $g$ & 4944 & g & 6967 & 0 & 9889 \\
\hline
\end{tabular}

Tons of Flouride Released to Air

\begin{tabular}{|c|c|c|c|c|c|c|}
\hline \multirow[b]{2}{*}{ Year } & \multicolumn{2}{|c|}{ All Coal Case } & \multicolumn{2}{|c|}{$50 / 50$ Case } & \multicolumn{2}{|c|}{ All Nuclear Caso } \\
\hline & Co. 1 & Nuclear & Coal & Nuclear & Coal & Nuclear \\
\hline 1995 & 9 & 3 & ต & 4 & g & 4 \\
\hline 2605 & g & 4 & 0 & 5 & 6 & 6 \\
\hline 2015 & 0 & 4 & g & 7 & 0 & 9 \\
\hline 2925 & 0 & 4 & $\theta$ & 9 & (0) & 14 \\
\hline 2637 & (1) & 3 & g & 13 & 0 & 23 \\
\hline otal & 6 & 202 & 6 & 348 & פ & 494 \\
\hline
\end{tabular}

- Shipments will begin when a licensed facility is available. 


\section{Low Grouth Scenario (contd)}

Millions of Cubic Yards of Mine and Mill vaste

\begin{tabular}{|c|c|c|c|c|c|c|}
\hline \multirow[b]{2}{*}{ Year } & \multicolumn{2}{|c|}{ Alf Coal Case } & \multicolumn{2}{|c|}{$50 / 50$ Case } & \multicolumn{2}{|c|}{ All Nuclear Case } \\
\hline & Coal & Nuclear & Coal & Nuclear & Coal & Nuclear \\
\hline 1995 & 93 & 11 & 94 & 13 & 89 & 15 \\
\hline 2065 & 169 & 15 & 164 & 17 & 99 & 18 \\
\hline 2015 & 134 & 15 & 112 & 22 & 91 & 30 \\
\hline 2625 & 162 & 15 & 118 & 36 & 75 & 48 \\
\hline 2637 & 218 & 9 & 125 & 42 & 33 & 75 \\
\hline Total & 6755 & 664 & 5418 & 1145 & 4683 & 1625 \\
\hline
\end{tabular}

Cunulative Consumption of $\mathrm{Coal}$ and $\mathrm{U}_{3} \mathrm{O}_{8}$ (Uillions of Tons)

\begin{tabular}{|c|c|c|c|c|c|c|}
\hline \multirow[b]{2}{*}{ Year } & AlI & \multirow{2}{*}{$\frac{12 \text { Case }}{\text { Nuclear }}$} & $50 / 50$ & \multirow{2}{*}{$\frac{\text { Case }}{\text { Huclear }}$} & \multicolumn{2}{|c|}{ All Nuclear Case } \\
\hline & Coal & & Con & & Coal & Nuclear \\
\hline & 4788 & 6.11 & 4499 & b.13 & 4230 & 0.15 \\
\hline & 11286 & 0.30 & 16833 & 6.33 & 10380 & 6. 38 \\
\hline & 19028 & 6.49 & 17743 & ๑.59 & 16458 & 6.69 \\
\hline 26 & 28432 & 0.69 & 25672 & 0.95 & 21711 & 1.21 \\
\hline 263 & 42749 & 0.90 & 34295 & 1.54 & 25848 & 2.19 \\
\hline
\end{tabular}

Tota
Cubic Yards of High Level Radioactive Waste

\begin{tabular}{|c|c|c|c|c|c|c|}
\hline \multirow[b]{2}{*}{ Year } & AlI & \multirow{2}{*}{$\begin{array}{c}\text { Coal Case } \\
\text { Nuclear }\end{array}$} & \multicolumn{2}{|c|}{$50 / 50$ Case } & \multicolumn{2}{|c|}{ All Nuclear Case } \\
\hline & Coa & & Coal & Nuclear & $\cos 1$ & Nuclear \\
\hline 1995 & 6 & 1072 & 0 & 1255 & 6 & 1438 \\
\hline 2065 & (1) & 1443 & ⿹ & 1818 & 6 & 1792 \\
\hline 2015 & g & 1443 & 6 & 2191 & $\theta$ & 2939 \\
\hline 2025 & - & 1441 & 6 & 2959 & c & 4478 \\
\hline 2637 & 6 & 862 & $\theta$ & 4169 & y & 7355 \\
\hline Total & $\theta$ & 64994 & (อ & 111962 & ø & 158931 \\
\hline
\end{tabular}

Willions of Separative Work Units for Uraniun Enrichnent

\begin{tabular}{|c|c|c|c|c|c|c|}
\hline \multirow[b]{2}{*}{ Year } & \multicolumn{2}{|c|}{ All Coal Case } & \multicolumn{2}{|c|}{$50 / 50$ Case } & \multicolumn{2}{|c|}{ All Nuclear Case } \\
\hline & Coal & Nuclear & Coa & Nuclear & Coal & Nuclear \\
\hline 1995 & $\theta$ & $\mathbf{B}$ & 0 & 9 & 6 & 10 \\
\hline 200 & 6 & 18 & g & 12 & $\theta$ & 13 \\
\hline 2915 & б & 10 & g & 16 & 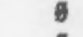 & 21 \\
\hline & 6 & 10 & 6 & 21 & 0 & 32 \\
\hline 203 & $\theta$ & 6 & 6 & 30 & g & 53 \\
\hline
\end{tabular}


Middle Grouth Scenario

Electricity Generation (billions of kwh)

\begin{tabular}{|c|c|c|c|c|c|c|}
\hline \multirow[b]{2}{*}{ Year } & \multicolumn{2}{|c|}{ All Coal Case } & \multicolumn{2}{|c|}{$50 / 50$ Case } & \multicolumn{2}{|c|}{ All Nuclear Case } \\
\hline & Coal & Nuclear & Coal & Nuctear & Coal & NucTear \\
\hline 1995 & 1551 & 639 & 1550 & 646 & 1549 & 842 \\
\hline 2005 & 2162 & 641 & 1868 & 996 & 1454 & 1350 \\
\hline 2015 & 2949 & 648 & 2980 & 1589 & 1211 & 2378 \\
\hline 2625 & 4161 & 433 & 2413 & 2181 & 665 & 3929 \\
\hline 2637 & 8169 & 69 & 3172 & 3606 & 235 & 5943 \\
\hline Tota & 153224 & 26395 & 103728 & 75893 & 54228 & 125391 \\
\hline
\end{tabular}

Nuaber of 100 Car Coal Trains

T.

or
Annual Rate of Change in Generation for Selected Years Percent Change fron Provious Year

\begin{tabular}{|c|c|c|c|c|c|}
\hline \multirow[b]{2}{*}{ Year } & All Coal Case & \multicolumn{2}{|c|}{ 50/50 Case } & \multicolumn{2}{|c|}{ All Nuelear Case } \\
\hline & Coal Nuclear & Coal & Nuclear & Cool & Nuclear \\
\hline 1995 & 2.25 & $2.5 \%$ & $2.5 \%$ & & $1.7 \mathrm{x}$ \\
\hline 2605 & $3.3 \%$ & $1.4 \%$ & $4.6 x$ & & $7.0 x$ \\
\hline 2015 & $3.1 \%$ & $1.6 \%$ & $3.8 \%$ & & $5.6 \%$ \\
\hline 2025 & $3.8 x$ & $1.9 \%$ & $3.1 \%$ & & $4.6 \mathrm{x}$ \\
\hline 2937 & $3.8 x$ & $3.6 x$ & $2.6 \%$ & & $3.2 x$ \\
\hline
\end{tabular}

Millions of Tons of Carbon Dioxide Released

\begin{tabular}{|c|c|c|c|c|c|c|}
\hline \multirow[b]{2}{*}{ Year } & \multicolumn{2}{|c|}{ All Coal Case } & \multicolumn{2}{|c|}{$50 / 50$ Case } & \multicolumn{2}{|c|}{ All Nuclear Case } \\
\hline & Coal & Nuclear & Coal & Nuclear & Coal & Nuclear \\
\hline 1995 & 69890 & 9 & 69743 & (6) & 69687 & (6) \\
\hline 2065 & 97384 & $\theta$ & 81357 & g & 65410 & 0 \\
\hline 2615 & 132685 & 6 & 93584 & g & 54484 & g \\
\hline 2025 & 187239 & 0 & 198580 & g & 29921 & b \\
\hline 2937 & 274926 & 0 & 142780 & (6) & 16595 & b \\
\hline Total & 6895062 & 6 & 4667667 & 6 & 2440271 & ש \\
\hline
\end{tabular}

\begin{tabular}{|c|c|c|}
\hline \multirow[b]{2}{*}{ Year } & \multicolumn{2}{|c|}{ All Coal Case } \\
\hline & Coal & Nuclear \\
\hline 1995 & 2616 & (6) \\
\hline 2095 & 2811 & 0 \\
\hline 2015 & 3833 & $\emptyset$ \\
\hline 2025 & 5489 & 6 \\
\hline 2937 & 7942 & 6 \\
\hline Total & 199191 & $\emptyset$ \\
\hline
\end{tabular}

$\begin{array}{ccc}50 / 50 & \text { Case } \\ \frac{\text { Coal }}{2015} & \text { Nuclear } \\ 2015 & 0 \\ 2350 & 6 \\ 2794 & 6 \\ 3137 & 6 \\ 4124 & 0 \\ 134844 & 0\end{array}$

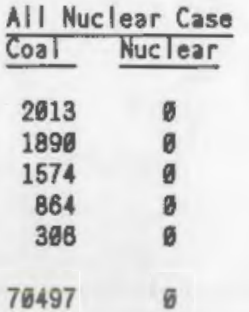

Thousands of Cubic Yards of Nonradioactive Solids

\begin{tabular}{|c|c|c|c|c|c|c|}
\hline \multirow[b]{2}{*}{ Year } & \multicolumn{2}{|c|}{ All Coal Case } & \multicolumn{2}{|c|}{ 50/50 Case } & \multicolumn{2}{|c|}{ All Nuclear Case } \\
\hline & Coal & Nuclear & Coal & Nuclear & Coal & Nuclear \\
\hline 1995 & 748 & 18 & 747 & 18 & 748 & 18 \\
\hline & 1642 & 18 & 871 & 28 & 701 & 38 \\
\hline 2615 & 1421 & 18 & 1002 & 42 & 584 & 86 \\
\hline 2925 & 2006 & 12 & 1183 & 81 & 320 & 169 \\
\hline 2037 & 2945 & 2 & 1529 & 84 & 113 & 165 \\
\hline ot: & 73854 & 734 & 49996 & 2110 & 26138 & 3486 \\
\hline
\end{tabular}

All Nuclear Case
Coal Nuclear

\begin{tabular}{|c|c|}
\hline $50 / 50$ & Case \\
\hline $\cos { }^{1}$ & Nuclear \\
\hline 102300 & 5 \\
\hline 119328 & 8 \\
\hline 137280 & 12 \\
\hline 159258 & 17 \\
\hline 289352 & 23 \\
\hline
\end{tabular}

\begin{tabular}{rr}
102234 & 5 \\
95964 & 11 \\
79926 & 19 \\
43890 & 31 \\
15510 & 46 \\
& \\
\hline 579048 & 978
\end{tabular}


Middle Grouth Scenario (contd)

Thousands of Tons of Sulfur Oxides Released (Assuming 9ax Recovery in Scrubbers)

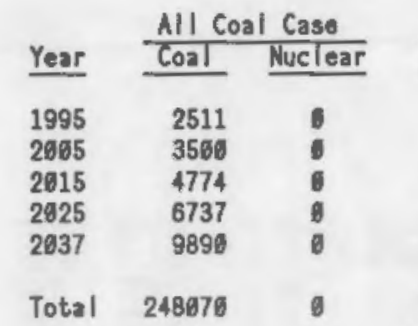

\section{All Nuclear Case} Coal Nuclear

2586

235

1961

1077
380

87795

Thousands of Tons of Oxides of Nitrogen Released (Assuning Maxiaun Allowable Released)

\begin{tabular}{|c|c|c|c|c|c|c|}
\hline \multirow[b]{2}{*}{ Year } & \multicolumn{2}{|c|}{ All Coal Case } & \multicolumn{2}{|c|}{ 50/50 Case } & \multicolumn{2}{|c|}{ All Nuclear Case } \\
\hline & Coal & Nuclear & Co21 & Nuclear & Coal & Nuclear \\
\hline 1995 & 3496 & 5 & 3487 & 1 & 3484 & 6 \\
\hline 2085 & 4865 & • & 4688 & - & 3271 & ต \\
\hline 2815 & 6834 & - & 4679 & g & 2724 & g \\
\hline 2025 & 9362 & g & 5429 & 1 & 1496 & 0 \\
\hline 2637 & 13746 & - & 7138 & 0 & 530 & 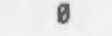 \\
\hline Total & 344753 & 0 & 233383 & 8 & 122614 & (9) \\
\hline
\end{tabular}

Thousands of Tons of Coal or Uraniun Shipped

Thousands of Cubic Yards of Lom Level Radioactive Waste

\begin{tabular}{|c|c|c|c|c|c|c|}
\hline \multirow[b]{2}{*}{ Year } & \multirow{2}{*}{$\frac{\text { All Coal }}{\text { Coal }}$} & \multirow{2}{*}{$\begin{array}{l}\text { Case } \\
\text { Nuclear }\end{array}$} & \multicolumn{2}{|c|}{ 58/50 Case } & \multicolumn{2}{|c|}{ All Nuclear Case } \\
\hline & & & Coal & Nuclear & Cogl & Nuclear \\
\hline 1995 & 628197 & 22 & 627690 & 22 & 627183 & 22 \\
\hline 2605 & 875738 & 22 & 732215 & 35 & 588693 & 47 \\
\hline 2015 & 1194167 & 22 & 842268 & 53 & 499354 & 83 \\
\hline 2625 & 1685154 & 15 & 977224 & 76 & 269293 & 138 \\
\hline 2937 & 2474331 & 2 & 1284841 & 165 & 95352 & 298 \\
\hline otal & 62655562 & 924 & 42909662 & 2656 & 21962442 & 4389 \\
\hline
\end{tabular}

Requirements* for Spent Fuel Shipnents Assun ing Rail

$$
\text { (Mitiply by Six for Truck) }
$$

\begin{tabular}{|c|c|c|c|c|c|c|}
\hline \multirow[b]{2}{*}{ Year } & \multicolumn{2}{|c|}{ All Coal Case } & \multicolumn{2}{|c|}{$50 / 50$ Case } & \multicolumn{2}{|c|}{ All Nuclear Case } \\
\hline & Coal & Tuclear & Coal & Nuclear & Coal & Nuclear \\
\hline 1995 & $\theta$ & 493 & 6 & 463 & 0 & 404 \\
\hline 2695 & 0 & 404 & 0 & 627 & 6 & 851 \\
\hline 2015 & $g$ & 403 & 0 & 951 & 0 & 1498 \\
\hline 2625 & 0 & 273 & 0 & 1374 & 6 & 2475 \\
\hline 2637 & c & 44 & 6 & 1894 & 0 & 3744 \\
\hline Total & อ & 18629 & 0 & 47813 & 0 & 78996 \\
\hline
\end{tabular}

- Shipments will begin when a licensed facility is available.

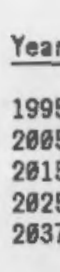

Tons of Flouride Released to Air $\frac{\text { All Coal Case }}{\text { Coal Nuclear }} \frac{50 / 50 \text { Case }}{\text { Coal Nuclear }}$

\section{$\frac{\text { All Nuclear Case }}{\text { Coal Nuclear }}$}

2065

2815

2625

Total

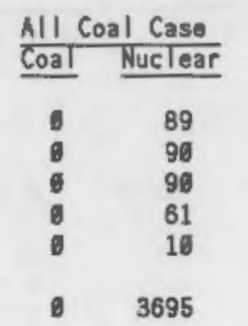

50/58 Case

$\frac{\text { All Nuclear Case }}{\text { Coal huclear }}$

\begin{tabular}{rr}
0 & 99 \\
0 & 139 \\
0 & 211 \\
0 & 395 \\
& 16621 \\
\hline
\end{tabular}

- 96

189

- $\quad 550$

- 17555 
Middle Growth Scenario (contd)

Millions of Cubic Yards of Mine and Mill Waste

\begin{tabular}{|c|c|c|c|c|c|c|}
\hline \multirow[b]{2}{*}{ Year } & \multicolumn{2}{|c|}{ All Coal Case } & \multicolumn{2}{|c|}{$50 / 56$ Case } & \multicolumn{2}{|c|}{ All Nuclear Case } \\
\hline & Coal & Nuclear & Coal & Nuclear & Coal & Kuclear \\
\hline 1995 & 99 & 15 & 99 & 15 & 99 & 15 \\
\hline 2005 & 138 & 15 & 118 & 23 & 93 & 31 \\
\hline 2015 & 189 & 15 & 133 & 35 & 77 & 55 \\
\hline 2025 & 266 & 18 & 154 & 50 & 43 & 96 \\
\hline 2937 & 391 & 2 & 263 & 69 & 15 & 137 \\
\hline Total & 9866 & 607 & 6638 & 1746 & 3471 & 2884 \\
\hline
\end{tabular}

Cumulative Consumption of $\mathrm{Coal}$ and $\mathrm{U}_{3} \mathrm{O}_{3}$ (Uillions of Tons)

\begin{tabular}{|c|c|c|c|c|c|c|}
\hline & \multicolumn{2}{|c|}{ All Coal Case } & $50 / 58$ & Case & \multicolumn{2}{|c|}{ All Nuclear Case } \\
\hline Yea & Coal & Nuclear & Coal & Kuclear & Cos & Nuclear \\
\hline 199 & 4769 & 0.13 & 4643 & 6.14 & 4517 & 0.15 \\
\hline 2 & 12358 & 6.33 & 11540 & 0.40 & 16722 & 0.46 \\
\hline 281 & 22862 & 0.53 & 19458 & 6.79 & 16114 & 1.64 \\
\hline 2025 & 37166 & 6.71 & 28564 & 1.37 & 19962 & 2.03 \\
\hline 2037 & 62956 & 6.82 & 42609 & 2.35 & 21962 & 3.89 \\
\hline
\end{tabular}

Cubic Yards of High Level Radioactive Waste

\begin{tabular}{|c|c|c|c|c|c|c|}
\hline \multirow[b]{2}{*}{ Year } & \multicolumn{2}{|c|}{ All Coal Case } & \multicolumn{2}{|c|}{ 50/50 Case } & \multicolumn{2}{|c|}{ All Nuclear Case } \\
\hline & Coat & Nuclear & Coal & Nuclear & Coal & Nuclear \\
\hline 1995 & 0 & 1438 & 6 & 1441 & 6 & 1444 \\
\hline 2605 & e & 1443 & ø & 2240 & g & 3938 \\
\hline 2015 & 6 & 1441 & G & 3396 & $g$ & 5351 \\
\hline 2625 & 6 & 975 & (6) & 4998 & 6 & 8841 \\
\hline 2637 & 6 & 155 & $\theta$ & 6764 & 0 & 13372 \\
\hline Tota! & $\theta$ & 59396 & 6 & 170759 & $\theta$ & 282129 \\
\hline
\end{tabular}

Millions of Separative Work Units for Uranium Enrichment

\begin{tabular}{|c|c|c|c|c|c|c|}
\hline \multirow[b]{2}{*}{ Year } & \multicolumn{2}{|c|}{ All Coal Case } & \multicolumn{2}{|c|}{ 50/56 Case } & \multicolumn{2}{|c|}{ All Nuclear Case } \\
\hline & Coal & Nuclear & Coa & Nuclear & Coa & Nuclear \\
\hline 1995 & $\theta$ & 10 & 6 & 16 & 6 & 10 \\
\hline 208 & 6 & 16 & 0 & 16 & 0 & 22 \\
\hline 2015 & 6 & 10 & 6 & 25 & $\theta$ & 39 \\
\hline 262 & $\theta$ & 7 & 0 & 38 & b & 64 \\
\hline 2637 & g & 1 & 0 & 49 & g & 97 \\
\hline
\end{tabular}


High Growth Scenario

Electricity Generation (billions of kWh)

\begin{tabular}{|c|c|c|c|c|c|c|}
\hline \multirow[b]{2}{*}{ Year } & \multicolumn{2}{|c|}{ All Coal Case } & \multicolumn{2}{|c|}{ 50/50 Case } & \multicolumn{2}{|c|}{ All Nuclear Caso } \\
\hline & Coal & Nuclear & Coal & Tuclear & Coal & Nuclear \\
\hline 1995 & 1728 & 639 & 1638 & 729 & 1549 & 818 \\
\hline 2665 & 2699 & 649 & 2634 & 1385 & 1370 & 1969 \\
\hline 2615 & 4277 & 433 & 2578 & 2146 & 882 & 3848 \\
\hline 2625 & 6446 & 198 & 3487 & 3157 & 529 & 6115 \\
\hline 2637 & 16039 & 6 & 5020 & 5020 & 0 & 18039 \\
\hline Total & 223244 & 20480 & 135286 & 168438 & 47329 & 196395 \\
\hline
\end{tabular}

Annual Rate of Change in Generation for Selected Years

Percent Change fros Previous Year

\begin{tabular}{|c|c|c|c|c|}
\hline \multirow[b]{2}{*}{ Year } & All Coal Case & \multicolumn{2}{|c|}{ 50/50 Case } & All Nuclear Case \\
\hline & Coal Nucloar & Coal & Huclear & Coal Nuclear \\
\hline 1995 & $4.8 x$ & $3.2 \times$ & 4.18 & $7.0 x$ \\
\hline 2605 & $4.4 \pi$ & $2.3 x$ & $5.4 x$ & 7.45 \\
\hline 2815 & $4.9 \%$ & $2.9 \%$ & $4.3 x$ & $5.9 \pi$ \\
\hline 2625 & $4.5 \pi$ & $3.6 x$ & $3.3 x$ & $4.3 x$ \\
\hline 2837 & $3.5 \%$ & $3.0 x$ & $4.9 x$ & 4. $6 x$ \\
\hline
\end{tabular}

Millions of Tons of Carbon Dioxide Released

Nunber of 160 Car Coal Trains

Millions of Tons of Coal Or Ore Mined

Thousands of Cubic Yards of Nonradioactive Solids

\begin{tabular}{|c|c|c|c|c|c|c|}
\hline \multirow[b]{2}{*}{ Year } & \multicolumn{2}{|c|}{ All Coal Case } & \multicolumn{2}{|c|}{$50 / 50$ Case } & \multicolumn{2}{|c|}{ All Nuclear Case } \\
\hline & Coal & Nuclear & Coal & Nuclear & Coal & Nuclear \\
\hline 1995 & 833 & 18 & 796 & 20 & 748 & 23 \\
\hline 2065 & 1301 & 18 & 980 & 38 & 660 & 55 \\
\hline 2615 & 2861 & 12 & 1239 & 60 & 418 & 107 \\
\hline 2025 & 3197 & 6 & 1881 & 88 & 255 & 170 \\
\hline 2637 & 4839 & o & 2426 & 146 & . & 279 \\
\hline Total & 107684 & 569 & 65268 & 3015 & 22812 & 5460 \\
\hline
\end{tabular}

\begin{tabular}{|c|c|c|c|c|c|c|}
\hline \multirow[b]{2}{*}{ Year } & \multicolumn{2}{|c|}{ All Coal Case } & \multicolumn{2}{|c|}{$56 / 50$ Caso } & \multicolumn{2}{|c|}{ All Nuclear Case } \\
\hline & Coal & Nuclear & Coal & Nuclear & Coal & Nuclear \\
\hline 1995 & 2248 & - & 2130 & 6 & 2613 & 0 \\
\hline 2605 & 3508 & (6) & 2644 & 6 & 1786 & - \\
\hline 2015 & 5580 & D & 3346 & 6 & 1121 & 6 \\
\hline 2625 & 8380 & 8 & 4534 & 0 & 687 & c \\
\hline 2637 & 13951 & 6 & 6526 & 5 & 1 & 0 \\
\hline Total & 299217 & c & 175872 & 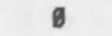 & 81527 & (6) \\
\hline
\end{tabular}


High Growth Scenario (contd)

Thousands of Tons of Sulfur Bxides Released (Assuming 96\% Recovery in Scrubbers)

\begin{tabular}{|c|c|c|}
\hline \multirow[b]{2}{*}{ Year } & \multicolumn{2}{|c|}{ All Coal Case } \\
\hline & Coal & Nuclear \\
\hline 1995 & 2798 & 0 \\
\hline 2965 & 4376 & 0 \\
\hline 2815 & 6924 & 0 \\
\hline 2025 & 16436 & $\emptyset$ \\
\hline 2937 & 16253 & $\emptyset$ \\
\hline Total & 361432 & 6 \\
\hline
\end{tabular}

Thousands of Tons of Coal or Uranium Shipped

i
Thousands of Tons of Oxides of Mitrogen Relaased (Assuning Haxinun Allowable Roleased)

\begin{tabular}{|c|c|c|c|c|c|c|}
\hline \multirow[b]{2}{*}{ Year } & \multicolumn{2}{|c|}{ All Coal Case } & \multicolumn{2}{|c|}{$50 / 50$ Case } & \multicolumn{2}{|c|}{ Al) Nuclear Case } \\
\hline & Coal & Nuclear & Coal & Nuclear & Coal & Nuclear \\
\hline 1995 & 3888 & g & 3686 & 6 & 3484 & g \\
\hline 2605 & 6072 & 6 & 4577 & g & 3982 & c \\
\hline 2015 & 9623 & 0 & 5782 & o & 1940 & 0 \\
\hline 2925 & 14563 & 6 & 7846 & b & 1190 & $\theta$ \\
\hline 2837 & 22589 & 0 & 11294 & 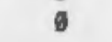 & I & 0 \\
\hline otal l l ot & 562299 & 0 & 364394 & g & 166490 & ต \\
\hline
\end{tabular}

Thousands of Cubic Yards of Low Level Radioactive Vaste

\begin{tabular}{|c|c|c|c|c|c|c|}
\hline \multirow[b]{2}{*}{ Year } & \multicolumn{2}{|c|}{ Al) Coal Case } & \multicolumn{2}{|c|}{$50 / 50$ Case } & \multicolumn{2}{|c|}{ All Nuclear Case } \\
\hline & Coa & Nuclear & Coa! & Nuclear & Coal & Nuclear \\
\hline 1995 & ø & 89 & b & 192 & ฮ & 115 \\
\hline 2685 & G & 98 & 6 & 183 & 6 & 276 \\
\hline 2015 & $\theta$ & 61 & 9 & 306 & 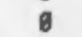 & 539 \\
\hline 2625 & 6 & 28 & 0 & 442 & 6 & 856 \\
\hline 2937 & g & ⿹ & 0 & 763 & c & 1466 \\
\hline Total & 0 & 2867 & 6 & 15181 & 6 & 27495 \\
\hline
\end{tabular}

Tons of Flouride Released to Air

$$
\text { (Muitiply by Six for Truek) }
$$

\begin{tabular}{|c|c|c|c|c|c|c|}
\hline \multirow[b]{2}{*}{ Year } & \multicolumn{2}{|c|}{ All Coal Case } & \multicolumn{2}{|c|}{$50 / 50$ Case } & \multicolumn{2}{|c|}{ All Nuclear Case } \\
\hline & Coal & Nuclear & Coal & Nuclear & Coal & Nuclear \\
\hline 1995 & 0 & 125 & 0 & 459 & g & 516 \\
\hline 2065 & 0 & 403 & 6 & 822 & 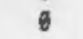 & 1241 \\
\hline 2815 & 6 & 273 & 0 & 1348 & (6) & 2424 \\
\hline 2625 & 0 & 125 & (1) & 1989 & 0 & 3853 \\
\hline 2037 & 9 & $\theta$ & 6 & 3162 & 6 & 6325 \\
\hline Tota I & $\emptyset$ & 12962 & ต & 68316 & 0 & 123729 \\
\hline
\end{tabular}

* Shipnents will begin when a licensed facility is ayailable.

\begin{tabular}{|c|c|c|c|c|c|c|}
\hline \multirow[b]{2}{*}{ Year } & \multirow{2}{*}{$\frac{\text { All }}{\text { Coa }}$} & \multirow{2}{*}{$\begin{array}{c}\text { Coal Case } \\
\text { Nuclear }\end{array}$} & \multicolumn{2}{|c|}{$50 / 50$ Case } & \multicolumn{2}{|c|}{ All Nuclear Case } \\
\hline & & & Coa & Nuclear & Coal & Nuclear \\
\hline 1995 & 0 & 4 & ต & 5 & 0 & 8 \\
\hline 2605 & 5 & 4 & 0 & 9 & 6 & 14 \\
\hline 2015 & 6 & 3 & 6 & 15 & 6 & 27 \\
\hline 2025 & g & 1 & 0 & 22 & 0 & 43 \\
\hline 2637 & g & 0 & ø & 35 & 0 & 70 \\
\hline ota & g & 143 & 0 & 759 & $\theta$ & 1375 \\
\hline
\end{tabular}


High Growth Scenario (contd)

Millions of Cubic Yards of Mine and Mill Waste

\begin{tabular}{|c|c|c|c|c|c|c|c|}
\hline \multirow{2}{*}{\multicolumn{2}{|c|}{ Year }} & \multicolumn{2}{|c|}{ All Coal Case } & \multicolumn{2}{|c|}{$56 / 50$ Case } & \multicolumn{2}{|c|}{ All Nuclear Case } \\
\hline & & Coal & Nuclear & Coal & Nuclear & Coal & Nuclear \\
\hline & 1995 & 111 & 15 & 165 & 17 & 99 & 19 \\
\hline & 2005 & 173 & 15 & 130 & 36 & 88 & 45 \\
\hline & 2615 & 274 & 10 & 164 & 49 & 55 & 88 \\
\hline & 2825 & 413 & 5 & 223 & 73 & 34 & 141 \\
\hline & 2637 & 643 & c & 321 & 115 & ! & 231 \\
\hline & Total & 14288 & 471 & 8658 & 2494 & 3829 & 4517 \\
\hline
\end{tabular}

Cumulative Consunption of Coal and $\mathrm{U}_{3} \mathrm{O}_{8}$

$$
\text { (Uillions of Tons) }
$$

\begin{tabular}{|c|c|c|c|c|c|c|}
\hline \multirow[b]{2}{*}{ Year } & \multicolumn{2}{|c|}{ All Coal Case } & $50 / 50$ & \multirow{2}{*}{$\begin{array}{l}\text { Case } \\
\text { Kuclear }\end{array}$} & \multicolumn{2}{|c|}{ All Nuclear Case } \\
\hline & Coal & Nuclear & Co:1 & & Coal & Ruclear \\
\hline 9 & 4929 & 6.14 & 4794 & 9.16 & 4659 & 6.17 \\
\hline 201 & 13974 & 0.34 & 12316 & 6.47 & 16659 & 0.60 \\
\hline 201 & 28666 & 0.52 & 21646 & 1.01 & 15225 & 1.59 \\
\hline 26: & 49897 & $\$ .62$ & 33891 & 1.85 & 17884 & 3.67 \\
\hline 205 & 90414 & 0.63 & 54791 & 3.38 & 19188 & 6.69 \\
\hline
\end{tabular}

Cubic Yards of High Levol Radioactive Waste

\begin{tabular}{|c|c|c|c|c|c|c|}
\hline \multirow[b]{2}{*}{ Year } & \multicolumn{2}{|c|}{ All Coal Case } & \multicolumn{2}{|c|}{ 50/50 Case } & \multicolumn{2}{|c|}{ All Nuclear Case } \\
\hline & Coal & Nuclear & Coal & Nuclear & & Nucloar \\
\hline 1995 & 6 & 1438 & B & 1846 & 6 & 1842 \\
\hline 2905 & o & 1441 & $\emptyset$ & 2938 & 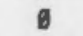 & 4431 \\
\hline 2015 & 0 & 975 & 0 & $481 B$ & 0 & 8857 \\
\hline 2625 & - & 446 & D & 7162 & - & 13759 \\
\hline 2937 & g & $\emptyset$ & 0 & 11294 & 6 & 22589 \\
\hline Total & b & 46080 & అ & 243985 & - & 441889 \\
\hline
\end{tabular}

Willions of Separative Dork Units for Uraniun Enrichnent

\begin{tabular}{|c|c|c|c|c|c|c|}
\hline \multirow[b]{2}{*}{ Year } & \multicolumn{2}{|c|}{ All Coal Case } & \multicolumn{2}{|c|}{ 56/50 Case } & \multicolumn{2}{|c|}{ All Nuclear Case } \\
\hline & Co: & Nuclear & Coal & Tuclear & Coal & Tuclear \\
\hline 1995 & 6 & 10 & 6 & 12 & (6 & 13 \\
\hline 206 & $\emptyset$ & 10 & 6 & 21 & 6 & 32 \\
\hline 2615 & 0 & 7 & c & 35 & 6 & 63 \\
\hline 2 262 & 0 & 3 & 6 & 51 & 0 & 100 \\
\hline 2937 & ต & 6 & 6 & 82 & c & 164 \\
\hline
\end{tabular}


APPENDIX G

FUEL CYCLE ASSUMPTIONS 
APPENDIX G

\section{FUEL CYCLE ASSUMPTIONS}

\section{DESCRIPTION OF COAL AND NUCLEAR FUEL CYCLES}

A brief description of the steps in each fuel cycle is presented below. The assumed values are representative of current technology for each fuel cycle. Over the long term improvements in coal technology are likely to be made in conversion efficiency, in controlling emissions, and in cleaning coal prior to combustion. Improvements in nuclear technology are likely to be made in conversion efficiency, where the potential is greater than for coal, in achieving higher fuel burnups, and in increasing fuel utilization efficiency through uranium and plutonium recycle and eventually breeding. Thus, the state of the art assumptions used below are likely to prove pessimistic and overstate the impacts over the long term.

\section{Coal Fuel Cycle}

Coal is produced from underground and surface mines. Most of the underground production (65\%) is in the eastern United States (NCA 85, p. 30). The western mines, which produced $35 \%$, are primarily surface mines. Since most reserves are in the West, the proportion of production in the West should gradually increase. Eastern coal is generally higher in sulfur content and heating value than western coal.

Coal varies widely in properties important to its use as a utility fuel. The sulfur content may range from 0.6 to $6.0 \%$. The ash content usually ranges from 8 to $12 \%$, although much higher values are possible. The heating values range from $6,000 \mathrm{Btu} / 1 \mathrm{~b}$ for lignite to $14,000 \mathrm{Btu} / 1 \mathrm{~b}$ for bituminous. As mined, coal is diluted with additional impurities. Coal preparation plants, located near the mine, remove most of the mine waste. Mine waste can range from negligible amounts to $30 \%$ or more. The coal composition and utilization assumptions used in this study are summarized in Table G.1. 
TABLE G.1. Assumptions Used in Coal Fuel Cycle Analysis

\section{Composition}

Heating value of as-burned coal: 21,000,000 Btu/ton, 10,500 Btu/1b $8,500 \mathrm{Btu} / \mathrm{kWh}$ (heat rate) (c)

Sulfur Content: $2.0 \%$

Ash Content: $10.0 \%$

Mine Waste: $16.0 \%$

Mine Waste Properties ${ }^{(a)}$

$\begin{aligned} \text { Dry Density } & =901 \mathrm{~b} / \mathrm{ft}^{3} \\ \text { Wet Density } & =106 \mathrm{1b} / \mathrm{ft}^{3} \\ \text { Specific Gravity } & =1.95\end{aligned}$

Sludge from Coal Preparation Plants

$$
\begin{array}{ll}
\text { Dry Density } & =54 \mathrm{lb} / \mathrm{ft}^{3} \\
\text { Wet Density } & =78 \mathrm{bb} / \mathrm{ft}^{3} \\
\text { Specific Gravity } & =1.36 \text { to } 1.66
\end{array}
$$

Coal Transport

90 tons coal/carload

100 cars/train; total length - 5,500 feet

Average speed $=10 \mathrm{miles} /$ hour

Average distance $=1,800$ miles round trip

Fraction hauled by rail $=64 \%$

Coal car utilization $=2,160$ hours per year

(hauling coal and returning)

Power Plant Waste Products (EPRI 84, pp. 3-50 to 3-53)

Solid Waste

Total ash $=$ Coal consumption $\times 0.10$

Total fly ash $=$ Total ash $\times 0.8$

Fly ash collected in precipitator $=$ Total fly ash $\times 0.9$

Total bottom ash $=$ Total ash - Total fly ash

(a) Wi 75, p. 398.

(b) Wi 75, p. 400 .

(c) The average heat rate experienced in 1987 was $10,200 \mathrm{Btu} / \mathrm{KWh}$. 


\section{TABLE G.1. (contd)}

\section{Power Plant Waste Products (contd)}

A Fly ash collected in scrubber $=$ Total fly ash $\times(0.997-0.900)$

B Weight of $\mathrm{CaSO}_{4} \cdot 2 \mathrm{H}_{2} \mathrm{O}=\mathrm{Coal}$ consumption $\times \% \mathrm{~S} \times 0.9 \times 0.2 \times \frac{172}{32}$

C Weight of $\mathrm{CaSO}_{4} \cdot 1 / 2 \mathrm{H}_{2} \mathrm{O}=$ Coal consumption $\times \% \mathrm{~S} \times 0.9 \times 0.8 \times \frac{145}{32}$

D Weight excess reagents as $\mathrm{CaCO}_{3}=$

Coal consumption $x \% S \times 0.9 \times \frac{100}{32} \times 0.2$

Total solids weight $=A+B+C+0$

Weight of water $=\frac{40}{60} \times$ Total solids weight

Total weight of sludge $=\frac{100}{60} \times$ Total solids weight

Bulk Density

Fly ash $=90 \mathrm{lb} / \mathrm{ft}^{3}$

Bottom ash $=80 \mathrm{lb} / \mathrm{ft}^{3}$

Dry $F G D$ sludge $=80 \mathrm{lb} / \mathrm{ft}^{3}$

Atmospheric Emissions

$\mathrm{CO}_{2}=44 / 12$ Carbon content

$\mathrm{SO}_{2}=0.4$ lb per million Btu assuming a scrubber efficiency of $90 \%$. The emission standard is 1.2 lb per million Btu $(\operatorname{Max})^{(a)}$

Particulates $=0.03 \mathrm{lb}$ per million Btu $(\text { Max })^{(\mathrm{a})}$

$\mathrm{NO}_{\mathrm{X}}=0.6$ lb per million Btu (Max) for bituminous coal ${ }^{(\mathrm{a})}$ 0.5 lb per million Btu (Max) for sub-bituminous coal ${ }^{(a)}$

(a) 40 CFR $60.42 a$. 
The fuel requirements and waste generation to produce one trillion KWh from coal under these assumptions is summarized in Figure G.1. Nuclear Fuel Cycle

In the United States, uranium is produced from underground and surface mines. The uranium content in the ore is low, about $0.2 \%$ for underground and about $0.1 \%$ for surface mines. Uranium is also produced as a by-product of other mining operations. The uranium is concentrated in mills located near the mines. Mill tailings are ponded near the mill; some are returned to the mine as back-fill. Disposal practices must guard against excessive radon releases from mill tailings to nearby populations. Uranium imports are substantial in relation to domestic production. In 1986, net imports exceeded United States mine production by $45 \%$ (DOE $87 a, p p .39,63$ ).

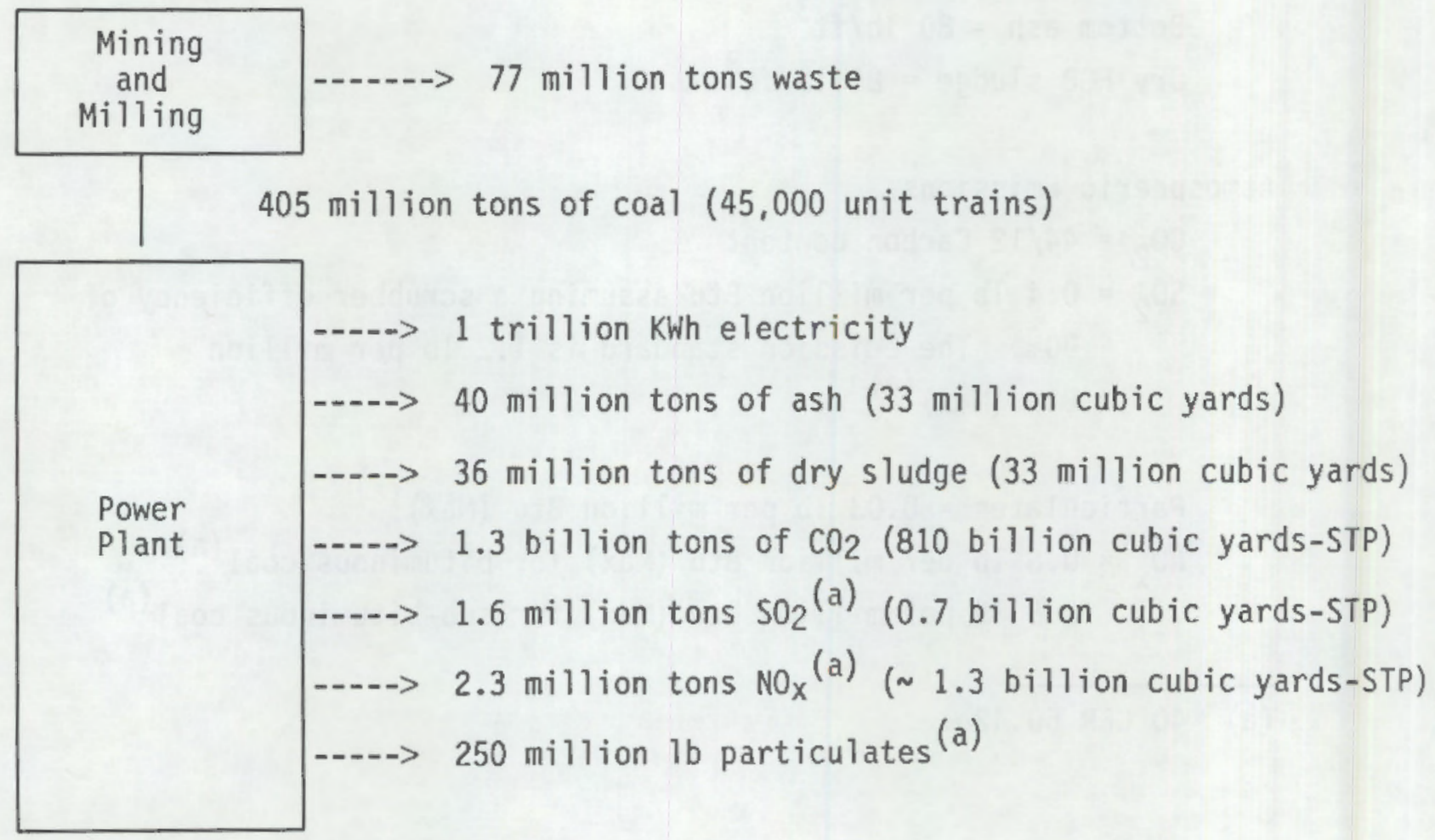

(a) Regulatory limits, actual emissions may be lower.

FIGURE G.1. Coal Plant Fuel Cycle Mass Flows 
The mill concentrate, as ammonium diuranate, is transported by truck or train to a conversion plant where it is converted into $\mathrm{UF}_{6}$. The UF 6 is transported by truck or train to an enrichment plant where the ${ }^{235} U$ content is increased three-to-five fold. Depleted uranium tails are produced and stored at the enrichment plant.

The enriched $\mathrm{UF}_{6}$ is transported by truck or train to a fuel fabrication plant. There it is converted to $\mathrm{UO}_{2}$ and fabricated into fuel assemblies. The fuel assemblies are transported by truck to the reactor site.

After irradiation and cooling at the reactor site the fuel assemblies will be transported by train or truck to a national waste disposal site.

The assumptions used in the nuclear scenarios are shown in Table G.2.

The fuel requirements and waste generation to produce one trillion KWh from nuclear fuel under these assumptions is summarized in Figure G.2.

Note that the shipments from the mine are 10,000 times greater by weight for a coal plant than for a nuclear plant. The coal plant burns 100,000 times more fuel by weight than the nuclear plant. For comparison, one PWR fuel assembly generates electricity equivalent to six coal trains, each with 100 cars (Figure G.3). Consequently, solid waste generation and atmospheric emissions from the coal plant are enormous, compared to the nuclear plant.

TABLE G.2. Nuclear Fuel Cycle Assumptions

Ore Grade

Mine Dilution

Milling Losses

Enrichment

Tails Composition

Fuel Exposure

Capacity Factor

Non-Radioactive Waste

Low Level Waste
$0.14 \% \mathrm{U}_{3} 08$

$10.0 \%$

$10.0 \%$.

$3.5 \% 235 U$

$0.25 \% 235 \mathrm{U}$

$37,500 \mathrm{MWd}(\mathrm{th}) /$ metric ton $(\mathrm{a})$

$65 \%$

0.25 cubic yards/ton of $\mathrm{U}_{3} \mathrm{O}_{8}$

136 cubic yards/TWh

(a) The average fuel exposure in 1987 was about $30,000 \mathrm{MWd} / \mathrm{MT}$. 

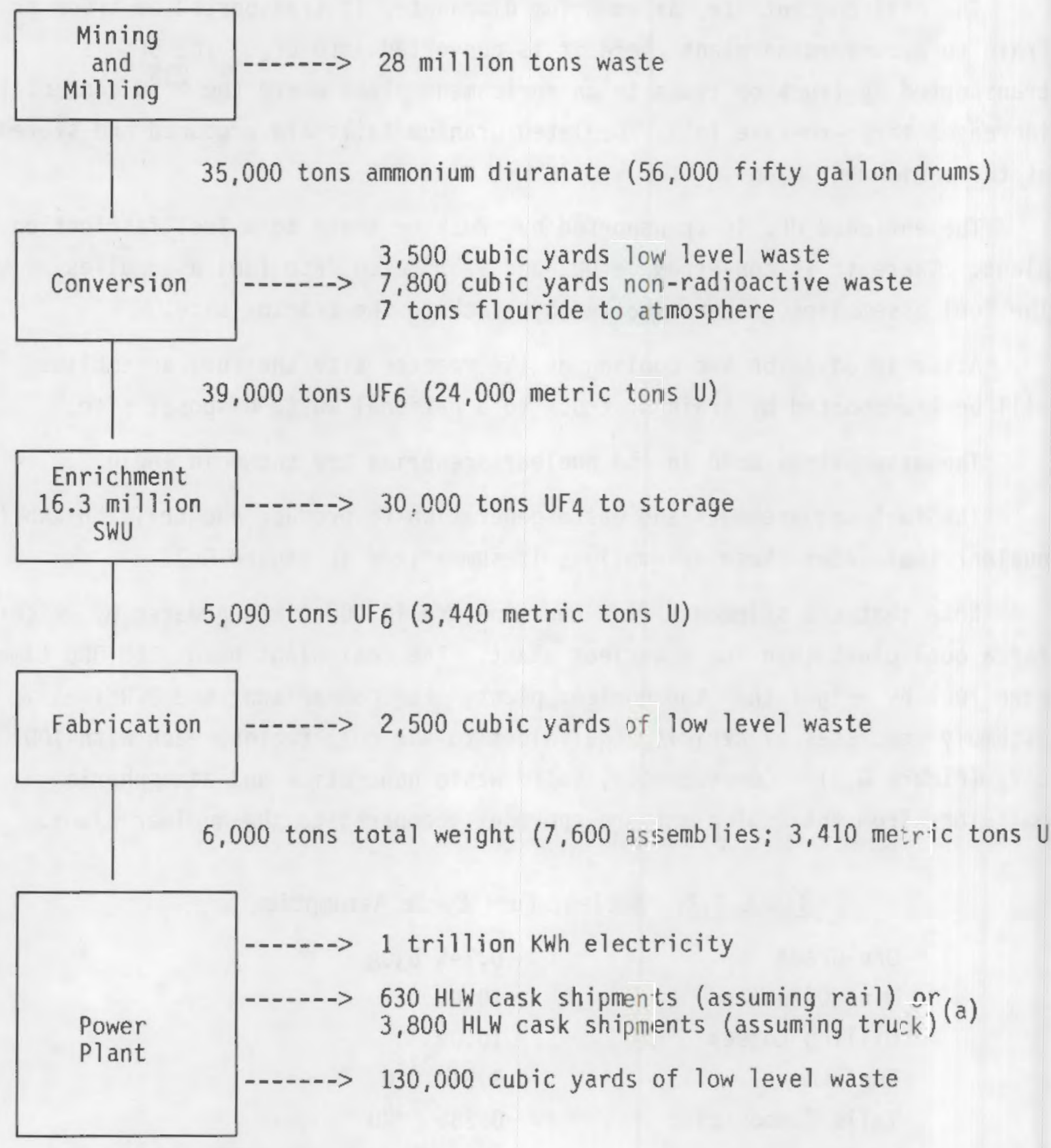

FIGURE G.2. Nuclear Plant Fuel Cycle Mass Flows

(a) 7600 spent fuel assemblies (shipped about 10 years after energy generation or when the repository is ready, whichever is later). 


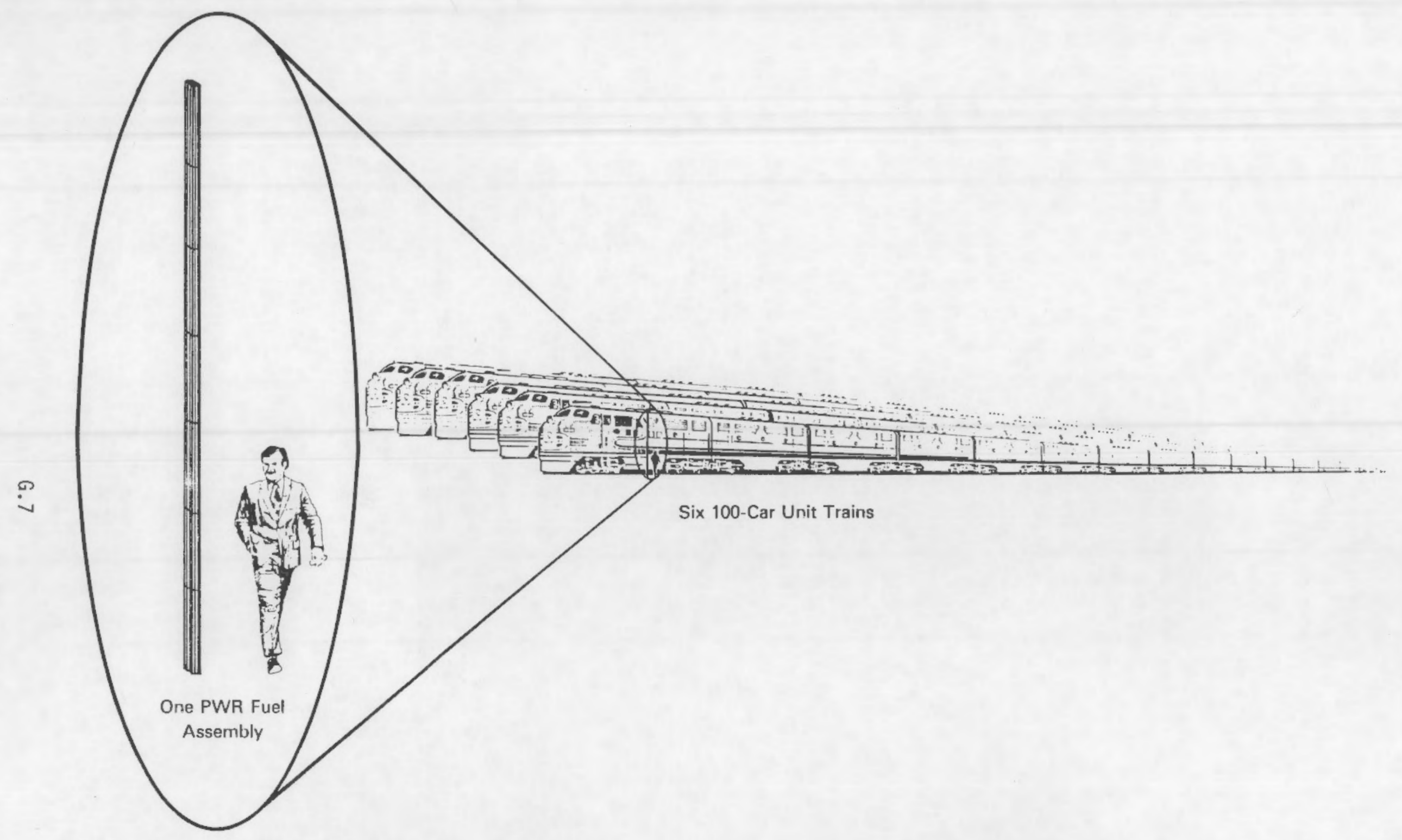

FIGURE G.3. Equivalent Electricity Generation 
APPENDIX H

ESTYMATED NUCLEAR CONTRIBUTION BY NERC REGION IN 1988 


\section{ESTIMATED NUCLEAR CONIRIBUTION BY NERC REGION IN 1988}

\begin{tabular}{|c|c|c|c|c|c|c|}
\hline \multirow[b]{2}{*}{ Region } & \multicolumn{3}{|c|}{ Energy Production, TWh } & \multicolumn{3}{|c|}{ Capacity, GW } \\
\hline & Nuclear & Total & $\%$ Nuclear & Nuclear & Total & $\%$ Nuclear \\
\hline ECAR & 38 & 432 & 9 & 7.7 & 97 & 8 \\
\hline ERCOT & 6 & 198 & 3 & 1.3 & 50 & 3 \\
\hline MAAC & 57 & 183 & 31 & 11.7 & 49 & 24 \\
\hline MAIN & 81 & 183 & 44 & 15.0 & 50 & 30 \\
\hline MAPP & 25 & 125 & 20 & 3.7 & 31 & 12 \\
\hline NPCC & 60 & 218 & 28 & 9.6 & 54 & 18 \\
\hline SERC & 156 & 572 & 27 & 27.9 & 139 & 20 \\
\hline SPP & 37 & 230 & 16 & 5.8 & 66 & 9 \\
\hline WSCC & 69 & 475 & 15 & 11.8 & 123 & 10 \\
\hline TOTAL & 529 & 2620 & 20 & 94.1 & 658 & 14 \\
\hline
\end{tabular}

NOTE: Totals may not add due to rounding.

Source: NERC 88

H.1 


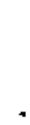




\section{DISTRIBUTION}

No. of

Copies

OFFSITE

111 DOE/Office of Scientific and Technical Information

50 E. Mastal

U.S. Department of Energy

Office of Nuclear Energy

19901 Gemantown Road

Germantown, MD 20874

J. Ahearne

Vice President

Resources for the Future, Inc.

1616 P Street, NW

Washington, DC 20036

W. Allen, Jr.

Chairman and CEO

Stone \& Webster, Inc.

PO Box 1244

New York, NY 10116

R. Balzhiser

President

Electric Power Research Institute

P0 Box 10412

Palo ATto, CA 94303

J. Barry

International President

International Brotherhood of Electrical Workers

1125-15th St., NW

Suite 1201

Washington, DC 20005

N. Beckman

Director, Washington Office

Council of State Governments

444 North Capitol Street, NW

Washington, DC 20001
No. of

Copies

\author{
S. Brewer \\ Executive Vice President \\ Nuclear Power Systems \\ Combustion-Engineering, Inc. \\ 1000 Prospect $\mathrm{Hill}$ Road \\ Windsor, CT 06095-1521 \\ R. Campbel1 \\ Chairman, President \& CEO \\ Pennsylvania Power and Light Co. \\ 2 North Ninth Street \\ Allentown, PA 18101 \\ D. Connor \\ Director, Energy Programs \\ Nat'l Conference of \\ St. Legislatures \\ 1D5D-17th Street \\ Suite 2100 \\ Denver, C0 80265 \\ T. Curtis \\ Director, Energy Committee \\ National Governors' Association \\ 444 North Capitol St., NW \\ Suite 250 \\ Washington, DC 20001 \\ G. Dau \\ Sr. Program Manager \\ Materials \& Systems Develop. Dept. \\ Electric Power Research Institute \\ P0 Box 10412 \\ Palo Alto, CA 94303 \\ W. Donnelly \\ Congressional Research Svc.-ENR \\ The Library of Congress \\ 101 Independence Avenue, SE \\ Washington, DC 20540
}


J. Eckert

Vice President and Group Executive Defense and Nuclear Power Group

Babcock \& Wilcox Company

PO Box 1165

Lynchburg, VA 24506-1165

\section{H. Finger \\ President and Chief Executive Officer}

U.S. Council for Energy Awareness

17761 I Street, NW

Suite 400

Washington, DC 20006-2495

R. Georgine

President

Building and Construction Trades

Dept.

AFL-CIO

815-16th Street, NW

Suite 603

Washington, DC 20006

D. Geraghty

Assistant to the President

Electric Power Research Institute

P0 Box 10412

Palo Alto, CA 94303

C. Grant

Vice President, Communications

Chamber of Commerce of the U.S.

$1615 \mathrm{H}$ Street, NW

Washington, DC 20006

R. Jones

Sr. Program Manager

Electric Power Research Institute Materials \& Systems Develop. Dept. P0 Box 10412

Palo Alto, CA 94303
F. Kalhammer

Energy Management \& Utilization

Electric Power Research Institute

PO Box 10412

Palo Alto, CA 94303

D. Louison

Director, Energy Programs

National Conference of

St. Legislatures

444 North Capitol Street, NW

Suite 203

Washington, DC 20001

N. Metzger

Deputy Director

Office of Government and

Public Affairs

National Academy of Sciences

2101 Constitution Avenue, NW

Washington, DC 20418

K. Miller

Sr. Planning Economist

Planning \& Evaluation Division

Electric Power Research Institute

P0 Box 10412

Palo Alto, CA 94303

D. Nevius

Vice President

North American Electric

Reliability Council

101 College Road East

Princeton, NJ 08540-6601

A. 0sso

Executive Director

National Association of State

Energy Officials

613 G Street, NW

5th Floor

Washington, DC 20001 
No. of

Copies

D. Ray

Dixy Lee Ray

600-3rd Avenue

Fox Island, WA 93888

\section{R. Ross}

Director, Energy Programs

Western Governors' Association 600-17th St.

Suite 1705, South Tower

Denver, CO 80202

D. Spencer

Advanced Power Systems

Electric Power Research Institute 3412 Hillview Avenue

Palo Alto, CA 94303

J. Taylor

Vice President \& Director

Nuclear Power Division

Electric Power Research Institute

3412 Hillview Avenue

Palo Alto, CA 94303

U.S, Council for Energy Awareness PO Box 1537

Ridgely, MO 21681

0 . Yu

Manager

Planning Evaluation Division

Electric Power Research Institute $3412 \mathrm{Hillview}$ Avenue

Palo Alto, CA 94303

R. Zeren

Director

Planning \& Evaluation Division

Electric Power Research Institute 3412 Hillview Avenue

Palo Alto, CA 94303
No. of

Copies

ONSI TE

DOE Richland Operations Office
D. R. Segna

53 Pacific Northwest Laboratory

C. H. Bloomster (20)

S. H. Bush

J. A. Christenson

T. T. Claudson

L. R. Dodd (10)

E. A. Eschbach

J. F. Fletcher

M. D. Freshley

S. W. Heaberlin

R. A. Libby

R. P. Marshall

J. P. McNeece

E. T. Merrill

R. E. Nightingale

A. W. Prichard

W. D. Richmond

W. B. Scott

B. D. Shipp

R. D. Widrig

Publishing Coordination

Technical Report Files (5)

Westinghouse-Hanford Company

H. D. Brager

L. G. Niccoli

J. A. Rawlins

A. E. Waltar 
1

, 